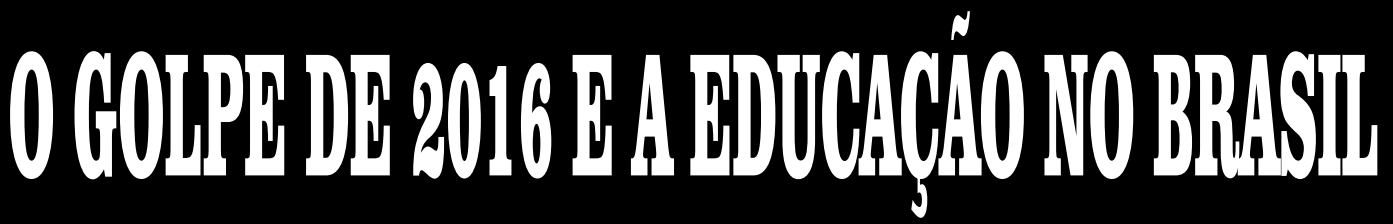

Nora Krawczyk José Claudinei Lombardi (Orgs.)

Barnabé Medeiros Filho - Dermeval Saviani - Marcos R. Lima - Debora Mazza

- Reginaldo C. Moraes - Roberto Heloani - Evaldo Piolli - Dirce Zan -

Nima I. Spigolon - Cristiane Machado - Mara R. M. Jacomeli Márcia L. A. Souza - Ana L. G. de Faria - Carlos E. A. Miranda Wenceslao M. de Oliveira Junior 

Nora Krawczyk

José Claudinei Lombardi

(Orgs.)

\section{O GOLPE DE 2016 E A EDUCAÇÃO NO BRASIL}

$1^{\mathrm{a}}$ Edição Eletrônica

Uberlândia / Minas Gerais

Navegando Publicações 2018

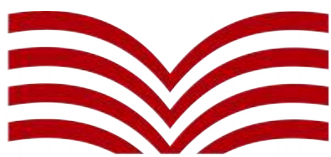

NAVEGANDO 


\section{Navegando Publicações \\ NAVEGANDO}

www.editoranavegando.com

editoranavegando@gmail.com

Uberlândia - MG,

Brasil

\section{Copyright () by autor, 2018.}

O112 - Krawczyk, Nora; Lombardi, José Claudinei (Orgs.). O golpe de 2016 e a educação no Brasil. Uberlândia: Navegando Publicações, 2018.

Vários Autores

ISBN: 978-85-53111-28-2

DOI: $10.29388 / 978-85-53111-28-2-0$

1. Educação 2. Golpe Parlamentar 3. Política Brasileira. I. Nora Krawczyk, José Claudinei Lombardi. II. Navegando Publicações. Título.

CDD - 320

CDU - 32

Revisão/Preparação - Lurdes Lucena

\section{Índices para catálogo sistemático}

Educação

370

Ciência Política 
NAVEGANDO www.editoranavegando.com editoranavegando@gmail.com Uberlândia - MG

Brasil

\section{Editores}

Carlos Lucena - UFU, Brasil

José Claudinei Lombardi - Unicamp, Brasil

José Carlos de Souza Araújo - Uniube/UFU, Brasil

\section{Conselho Editorial}

Afrânio Mendes Catani - USP, Brasil

Alberto L. Bialakowsky - Universidad de Buenos Aires, Argentina.

Ángela A. Fernández - Univ. Autónoma de Sto. Domingo, República Dominicana

Anselmo Alencar Colares - UFOPA, Brasil

Carlos Lucena - UFU, Brasil

Carlos Henrique de Carvalho - UFU, Brasil

Carolina Crisorio - Universidad de Buenos Aires, Argentina

Cílson César Fagiani - Uniube, Brasil

Christian Cwik - University of the West Indies, St.Augustine, Trinidad \& Tobago

Christian Hausser - Universidad de Talca, Chile

Daniel Schugurensky - Arizona State University, EUA

Dermeval Saviani - Unicamp, Brasil

Elizet Payne Iglesias - Universidad de Costa Rica, Costa Rica

Fabiane Santana Previtali - UFU, Brasil

Francisco Javier Maza Avila - Universidad de Cartagena, Colômbia

Gilberto Luiz Alves - UFMS, Brasil

Hernán Venegas Delgado - Universidad Autónoma de Coahuila, México

Iván Sánchez - Universidad del Magdalena -Colômbia

João dos Reis Silva Júnior - UFSCar, Brasil

Jorge Enrique Elías-Caro - Universidad del Magdalena, Colômbia

José Carlos de Souza Araújo - Uniube/UFU, Brasil

José Claudinei Lombardi - Unicamp, Brasil

José Jesus Borjón Nieto - El Colégio de Vera Cruz, México

José Luis Sanfelice - Univás/Unicamp, Brasil

Lívia Diana Rocha Magalhães - UESB, Brasil

Mara Regina Martins Jacomeli - Unicamp, Brasil

Miguel Perez - Universidade Nova Lisboa - Portugal

Newton Antonio Paciulli Bryan - Unicamp, Brasil

Paulino José Orso - Unioeste - Brasil

Raul Roman Romero - Universidad Nacional de Colombia - Colômbia

Ricardo Antunes - Unicamp, Brasil

Robson Luiz de França - UFU, Brasil

Sérgio Guerra Vilaboy - Universidad de la Habana, Cuba

Silvia Mancini - Université de Lausanne, Suíça

Teresa Medina - Universidade do Minho - Portugal

Tristan MacCoaw - Universit of London - Inglaterra

Valdemar Sguissardi - UFSCar - (Aposentado), Brasil

Victor-Jacinto Flecha - Universidad Católica Nuestra Señora de la Asunción, Paraguai

Yoel Cordoví Núñes - Instituto de História de Cuba, Cuba 



\section{Aos que lutam por uma sociedade justa e igualitária!}





\section{SUMÁRIO}

Introdução - Produzindo conhecimento sobre o golpe de 2016

Nora Krawczyk - José Claudinei Lombardi

I - O golpe no Brasil e a reorganização imperialista em tempo

de globalização

Barnabé Medeiros Filho

II - A crise política e o papel da educação na resistência ao

golpe de 2016 no Brasil

Dermeval Saviani

III - Golpes de Estado e educação no Brasil: a perpetuação

da farsa

José Claudinei Lombardi - Marcos R. Lima

IV - A revolução burguesa no Brasil e o golpe de 2016

Debora Mazza

V - O golpe de 2016, suas raízes. Perspectivas da resistência

Reginaldo C. Moraes

VI - A reforma trabalhista no Brasil e o golpe de 2016: uma abordagem sócio-jurídica

Roberto Heloani

VII - Mercantilização da educação, a reforma trabalhista e os

professores: o que vem por aî?

Evaldo Piolli

VIII - A disputa cultural: o pensamento conservador no ensino

médio brasileiro

Dirce Zan - Nora Krawczyk

IX - Formação de professores: o Estado pós-democrático, a ditadura e os golpes de 1964 e 2016 no Brasil

Nima I. Spigolon

$\mathrm{X}$ - O golpe e a gestão democrática das escolas

Cristiane Machado - Mara Regina Martins Jacomeli 
XI - Educação infantil em risco: "cadê o direito que estava aqui?! O golpe comeu!"

Marcia Lucia Anacleto Souza - Ana Lúcia Goulart de Faria

XII - Micropolíticas das imagens e sons do golpe - apontamentos

a partir do filme "O processo", de Maria Augusta Ramos

Carlos Eduardo Albuquerque Miranda - Wenceslao Machado de Oliveira Junior

Sobre os autores 




\section{INTRODUÇÃO \\ Produzindo conhecimento sobre o golpe de $2016^{*}$}

O presente livro reúne os textos resultantes das conferências proferidas, ao longo do primeiro semestre de 2018, no curso livre "O golpe de 2016 e a Educação no Brasil”, promovido pela Faculdade de Educação da Unicamp. Foi uma iniciativa tomada por docentes das mais diversas universidades brasileiras, praticamente em todas as regiões do território nacional, em promoverem cursos e seminários de teor semelhante ao promovido pelo Instituto de Ciência Política da Universidade de Brasília e que, por seu conteúdo e temática, sofreu fortes críticas e ameaça de processo judicial vindas do então ministro da Educação.

Era necessário manifestar nossa irrestrita solidariedade aos professores Luis Felipe Miguel e Karina Damous Duailibe, da Universidade de Brasília, reconhecendo a importância da iniciativa que tiveram em refletir sobre o Golpe de 2016, nos posicionando contrários às várias iniciativas desde então em andamento de liquidar com a autonomia universitária e a liberdade de pesquisa e ensino crítico na universidade. Com a imediata circulação da informação de tentativa de criminalizar e judicializar a pioneira iniciativa dos colegas da UnB, formatamos coletivamente um curso livre na Faculdade de Educação da Unicamp, focando particularmente no Golpe de 2016 e seus desdobramentos no processo de sucateamento da educação estatal (pública) brasileira. A proposta foi apresentada e aprovada no âmbito da Faculdade de Educação que, mais uma vez em sua curta, porém vigorosa história, se posicionava contra o arbítrio e em defesa da autonomia universitária e da liberdade de cátedra.

Mais do que reagir às ameaças e reafirmar a autonomia universitária, o livro aqui apresentado, tal como o curso que lhe deu origem, tem por objetivo refletir sobre o processo político recente do Brasil, socializando as elaborações conjunturais dos pesquisadores que toparam o desafio de participar do curso. Em última instância é defender a função fundamental da universidade, tão atacada nos últimos tempos:

"DOI - 10.29388/978-85-53111-28-2-()-f.1-4 
pesquisar de modo livre, crítico e independente, socializando os conhecimentos e reflexões produzidas através de um ensino público, gratuito, competente e socialmente referenciado. Em síntese, não é possível pensar a universidade, como uma instituição historicamente produzida, sem que exista autonomia e liberdade para pensar, debater e confrontar diferentes visões, métodos e teorias, sem as quais nenhum conhecimento novo se produz, nenhuma revolução filosófica, científica e artística seria possível.

A pergunta que orientou o curso e orienta este livro é: "Quais os efeitos para a educação brasileira do golpichment jurídico-parlamentar-midiático de 2016, contra a presidenta Dilma Rousseff e seus desdobramentos seguintes?". Para tanto, tratava-se de compreender as medidas tomadas no âmbito educativo pelo governo ilegítimo que se seguiu ao golpe e os interesses por ele atendidos. Era necessário entender o próprio golpe, as forças que o deflagraram, os interesses que o motivaram e como as diferentes iniciativas levadas a efeito em dois anos se encadeiam e se ligam à política educacional.

Foi a partir dessa ideia que se escolheu o capítulo " $O$ golpe de 2016 e a reorganização imperialista em tempo de globalização” para abrir o livro. Nele o jornalista Barnabé Medeiros Filho utiliza dados históricos para desvendar a face e os métodos do imperialismo estadounidense. Para ele, no golpe de 2016 a dimensão geopolítica foi tão ou mais importante que os interesses econômicos do imperialismo em relação ao Brasil.

Segue-se o capítulo “ A crise política e o papel da educação na resistência ao golpe de 2016 no Brasil”, do professor Dermeval Saviani, que analisa a crise política, destacando o comprometimento do Poder Judiciário no golpe. Na sequência, Saviani descreve o papel contraditório da educação na ordem democrático-burguesa.

Em “Golpes de Estado e educação no Brasil: a perpetuação da farsa”, os professores José Claudinei Lombardi e Marcos R. Lima, revelam a essência dos golpes ocorridos no Brasil ao longo de 130 anos. Para os autores, foram contrarrevoluções preventivas, através das quais as elites econômicas e políticas retomaram o poder, fazendo retroceder políticas sociais e populares.

No capítulo “A Revolução Burguesa no Brasil e o Golpe de 2016”, a professora Debora Mazza relaciona o golpe à função subal- 
terna da burguesia brasileira. Apoiando-se nas análises de diversos autores, particularmente em Florestan Fernandes, de quem extrai que a burguesia periférica, como é o caso da brasileira, é incapaz de conduzir uma revolução democrática nacional, mas "não deixa de permanecer no centro do controle do poder econômico, social e político”.

$\mathrm{O}$ professor Reginaldo Moraes recorre à "doutrina de choque”, descrita pela escritora canadense Naomi Klein, para identificar o método utilizado para viabilizar o golpe no Brasil: fabricar uma crise. Não importa que a crise seja real, basta que seja percebida como real por grandes parcelas da população. Assim tem sido no Brasil, particularmente a partir de 2013, explica o autor do capítulo " $O$ golpe de 2016, suas raízes. Perspectivas da resistência”

Em "Reforma trabalhista no Brasil e o golpe de 2016: uma abordagem sócio-jurídica” o professor Roberto Heloani apresenta uma radiografia dos retrocessos contidos na legislação trabalhista promulgada após o golpe. Para ele, essa reforma caracteriza-se pelo retorno ao ordenamento jurídico "como mecanismo de exclusão, segregação social e legalização da desigualdade”

Esse tema retorna no artigo "Mercantilização da educação, a reforma trabalhista e os professores: o que vem por aí.”, do professor Evaldo Piolli. O autor destaca dispositivos da nova legislação trabalhista, como o da terceirização da atividade fim, do trabalho intermitente e banco de horas como fatores que levarão à maior precarização do trabalho docente.

"A Disputa Cultural: o pensamento conservador no Ensino Médio brasileiro" é o título do capítulo das professoras Dirce Zan e Nora Krawczyk, no qual analisam o avanço do pensamento conservador na disputa pela escola pública. Para as autoras há uma disputa cultural focada na instituição escolar, que se expressa em iniciativas como a reforma do ensino médio e o projeto escola sem partido.

No capítulo "Formação de professores: o estado pós-democrático, a ditadura e os golpes de 1964 e 2016 no Brasil”, a professora Nima Spigolon utiliza conceitos do educador Paulo Freire para discutir o papel da universidade na formação de professores em tempos nos quais o estado democrático encontra-se sob ameaça.

O texto "Educação infantil em risco: 'cadê o direito que estava aqui!! O golpe comeu”, das professoras Marcia Lucia Anacleto Souza 
e Ana Lúcia Goulart de Faria, debate o direito constitucional a creches e pré-escola diante do avanço empresarial sobre a educação.

"O golpe e a gestão democrática das escolas", das professoras Cristiane Machado e Mara Regina Martins Jacomeli, analisa o corpo técnico oriundo do PSDB, que assumiu o Ministério da Educação com o golpe. $\mathrm{O}$ artigo mostra o viés autoritário das medidas emanadas do Ministério e o papel fundamental desse corpo técnico tucano na definição de tais medidas.

O capítulo "Micropolíticas das imagens e sons do golpe. Apontamentos a partir do filme 'O Processo', de Maria Augusta Ramos”, escrito pelos professores Carlos Eduardo Albuquerque Miranda e Wenceslao Machado de Oliveira Junior, é uma análise do documentário que mostra os bastidores no Congresso Nacional do impeachment da presidenta Dilma Rousseff.

Com o curso livre "O golpe de 2016 e a Educação no Brasil" e agora com o lançamento deste livro, a Faculdade de Educação da Unicamp reafirma, mais uma vez, seu compromisso com a construção de uma sociedade e de uma universidade regida pelo princípio democrático. Nestes tempos em que avança aceleradamente o desmonte da educação pública e sua mercadorização, reiteradamente os docentes, funcionários e alunos da FE tem se manifestado em defesa da educação pública, gratuita, competente e socialmente referenciada.

Boa leitura!

Sora Qrawczek Gosé Flautinei Rombardi 


\title{
I
}

\section{O GOLPE NO BRASIL E A REORGANIZAÇÃO IMPERIALISTA EM TEMPO DE GLOBALIZAÇÃO*}

\author{
Sarnabé Chedeiros ofilho
}

Embora os Estados Unidos não sejam o único país imperialista, constituem hoje a potência hegemônica mundial e, mais do que isso, são a potência a que, no Brasil, estamos diretamente submetidos. Por isso este artigo vai tratar essencialmente do imperialismo estadunidense, começando pela história de sua dominação sobre os países latino-americanos, e suas várias faces, ao longo dos últimos 170 anos.

Figura 1 - O imperialismo no século XIX

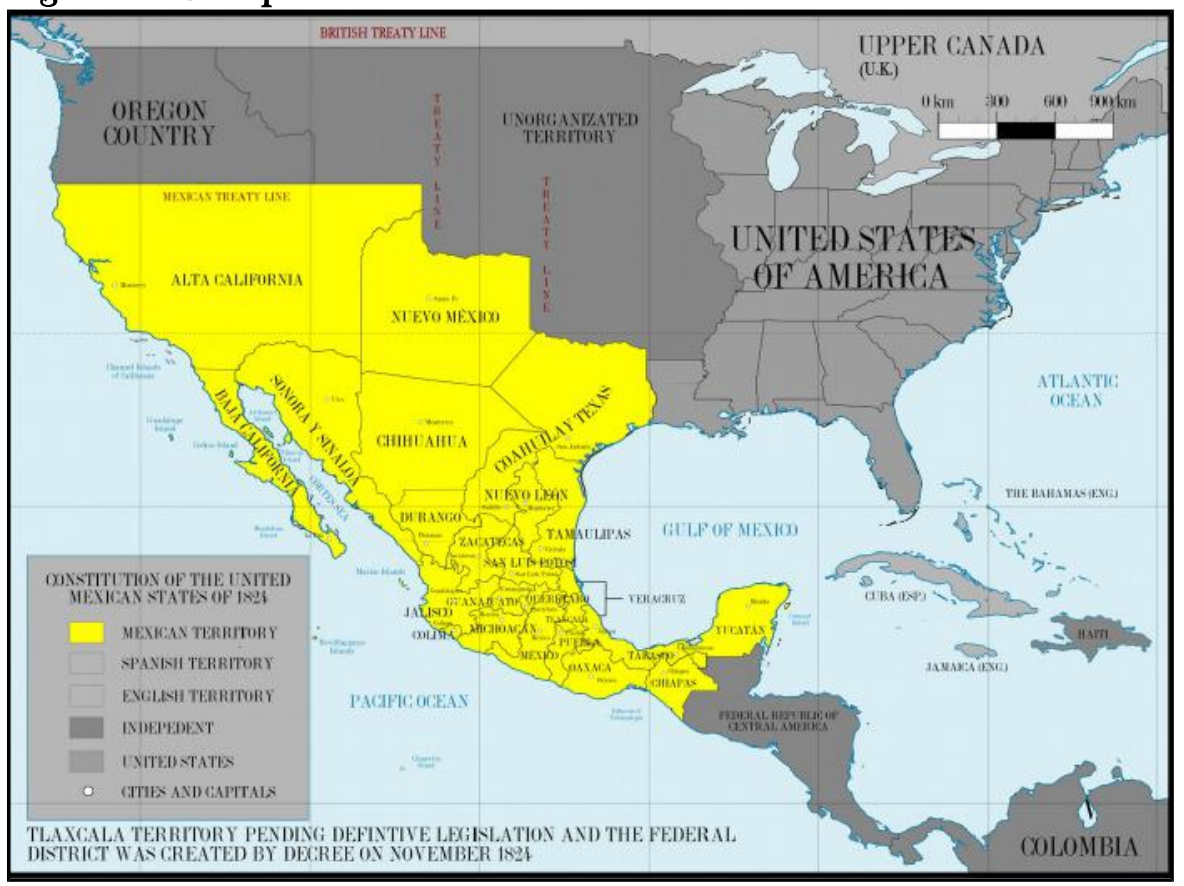

DOI - 10.29388/978-85-53111-28-2-0-f.5-26 
Este é o mapa de parte da América do Norte até 1845. O México é esta área em amarela. Era o maior e o mais importante país independente da América do Norte. Os Estados Unidos são este país na costa do Atlântico: menos da metade do território mexicano. Acima do México, na costa do Pacífico, está o Oregon, que no período em questão, pertencia à Grã-Bretanha. No meio está o oeste selvagem, que mais tarde o coronel Custer vai invadir com a cavalaria, matando índios, para abrir passagem aos "bravos" colonos dos filmes de faroeste.

Esse mapa começou a mudar em 1845, quando os Estados Unidos anexaram o Texas. Depois veio a guerra Mexicano-Americana ao fim da qual, em 1848, os Estados Unidos haviam tomado a metade do território mexicano.

Compare o mapa de 1845 com o mapa a seguir:

\section{Figura 2 - Mapa dos Estados Unidos e México}

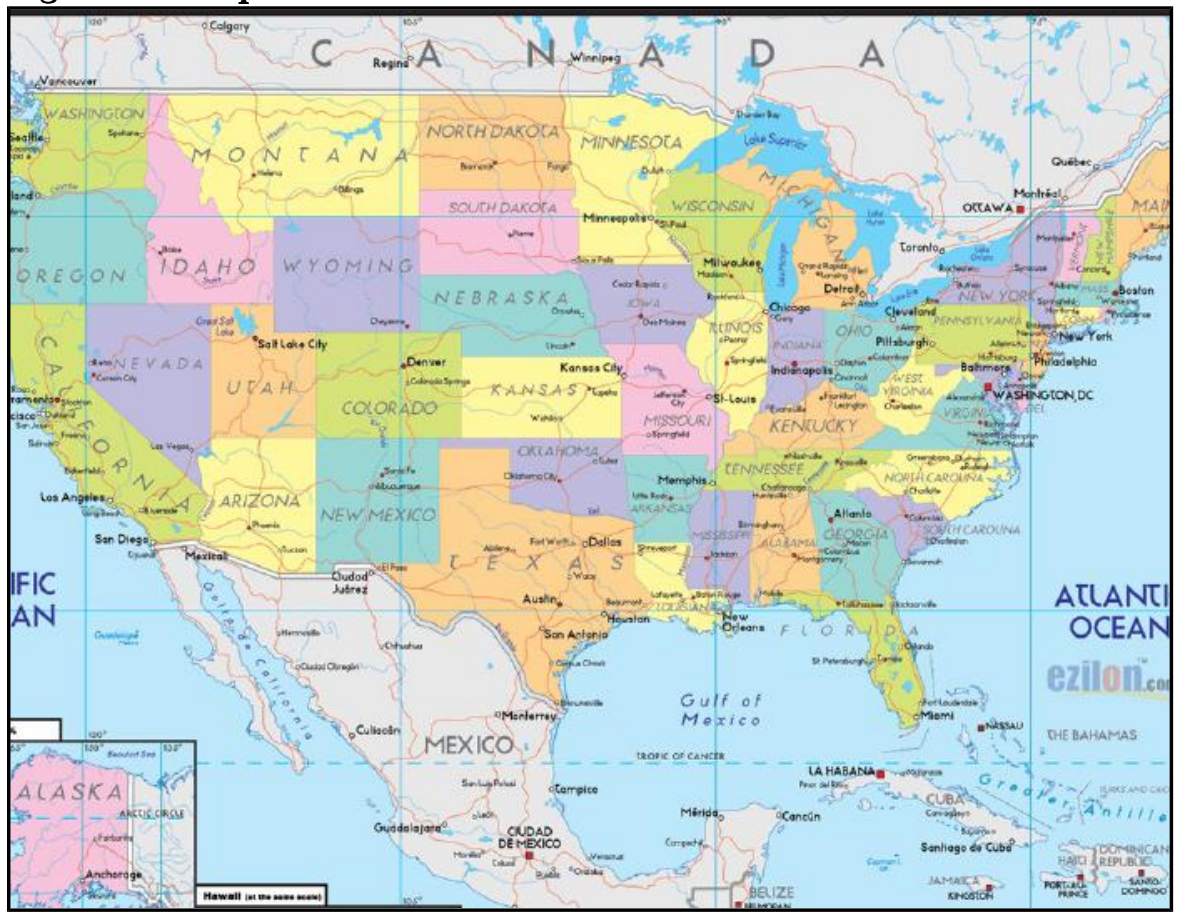


Na parte que os Estados Unidos tomaram estão hoje a Califórnia, onde pouco depois da anexação se descobriu ouro, e mais as áreas que correspondem aos estados de Nevada, Utah, Arizona, Novo México, Texas, parte do Colorado e parte do Wyoming.

Esse tipo de expansão, tomando territórios pela força, não era muito diferente do que as potências europeias faziam, sobretudo na África. Lá, conquistando colônias e na América do Norte ampliando fronteiras. Era o típico imperialismo do século XIX, embora o termo imperialismo ainda não existisse. Pelo menos não existia com o significado que tem hoje.

Qual era a justificativa ideológica dessa modalidade de imperialismo? No caso das potências europeias era levar civilização aos povos atrasados. Uma civilização levada na ponta das baionetas e convertida em espoliação.

Já os Estados Unidos tinham (de certa forma tem) uma justificativa ideológica muito peculiar, na qual racismo e religião se misturam. Trata-se da doutrina do destino manifesto, que começa a se difundir justamente no período da guerra contra o México. A doutrina do destino manifesto pregava que os Estados Unidos tinham o direito, dado por Deus, de se expandir por toda a América do Norte. Era a isso que a nação estava predestinada, por sua superioridade moral, devida ao caráter anglo-saxão e ao culto ao trabalho das vertentes protestantes predominantes no país. Uma estranha superioridade moral e um estranho culto ao trabalho que convivia pacificamente com a escravidão. Sem esquecer que após o fim da escravidão os negros ainda viveram mais 100 anos em um odioso sistema de apartheid.

Essa ideia, do destino manifesto, não foi apenas coisa do século XIX. Ela se manteve no século XX e era ensinada nas escolas de ensino fundamental e médio pelo menos até o início dos anos 60 . Naturalmente, não se tratava mais de expansão pela América do Norte, mas de "liderar o mundo", que numa leitura menos eufemística significava dominar o mundo.

\section{$\mathrm{O}$ imperialismo no século $\mathrm{XX}$}

Voltando à linha cronológica, o termo imperialismo surge, ou, pelo menos, se consolida, a partir da I Guerra Mundial, que ficou co- 
nhecida como a Grande Guerra imperialista, uma referência ao colonialismo das potências europeias em luta. É também a partir da I Guerra Mundial, com a enorme destruição causada pelo conflito, que os Estados Unidos se consolidam como potência de expressão mundial, com uma economia poderosa, capaz de balançar o mundo com suas crises, como foi com a crise de 1929.

Os Estados Unidos também tinham suas colônias: Filipinas e Porto Rico, tomados da Espanha em 1898, Havaí que era um país independente e foi invadido militarmente também em 1898, além de Cuba, mantida como uma semi-colônia por boa parte do século XX. Mas os Estados Unidos não foram um país essencialmente colonialista, como eram as potências europeias. Assim o século XX, ao longo do qual os Estados Unidos se consolidam como potência capitalista hegemônica, é marcado pelo declínio do imperialismo colonial e o gradativo surgimento de uma nova versão de imperialismo, que preserva a soberania dos países submetidos, dando ênfase ao domínio econômico, financeiro e cultural. Ou seja, o importante é ter países que sejam fornecedores de matéria prima, mercados para produtos industriais e receptores de investimentos para o capital excedente nos países centrais. Isso se pode conseguir mantendo esses países formalmente soberanos.

Naturalmente, quando algum desses países tributários sai da linha, uma intervençãozinha militar ajuda a corrigir o desvio. A Wikipédia traz uma cronologia das operações militares dos Estados Unidos no exterior ao longo de sua história. As do século XX somam 152 operações, aí incluindo as guerras mundiais, guerra do Vietnã, guerra do golfo, guerra da Coreia e intervenções menores englobando países tão diferentes como China e Iugoslávia, Irã e Congo, Síria e Tailândia. $\mathrm{Na}$ América Latina foram dezenas de intervenções, em países como Panamá, Cuba, Nicarágua, República Dominicana, Bermudas, Guatemala, El Salvador. Enfim, quase todos os países da América Central e Caribe sofreram algum tipo de intervenção militar dos Estados Unidos, vários deles mais de uma vez.

No caso dos grandes países da América Latina, o único a sofrer intervenção militar dos Estados Unidos foi o México. Já para nós, da América do Sul, que felizmente não estamos tão perto, foram reservados métodos indiretos de intervenção. 
Até os anos 70, o principal método de intervenção indireta dos EUA na América Latina consistia em cooptar as lideranças militares de cada país. Toda a cúpula militar do golpe de 1964 no Brasil tinha ligações estreitas com militares dos Estados Unidos, forjadas ao longo de décadas de contato e colaboração militar_entre os dois países. Castelo Branco, por exemplo, era amigo íntimo do coronel Vernon Walters, o adido militar da embaixada estadunidense e que foi um dos articuladores do golpe no Brasil.

Um dos instrumentos mais importantes para essa cooptação foi a Escola das Américas, na zona do canal do Panamá, um centro para treinamento e doutrinação ideológica de militares latino-americanos. Ela ficou conhecida como escola de ditadores, porque por lá passaram alguns dos golpistas mais famosos da América Latina, como Rafael Videla e Leopoldo Gualtiere da Argentina, Hugo Banzer da Bolívia, Manuel Contreras, do Chile.

O Brasil mandou centenas de militares para essa escola, o mais conhecido dos quais é o brigadeiro João Paulo Burnier, que chefiou o CISA, centro de tortura da Aeronáutica. Aliás, entre os vários cursos da Escola das Américas, um era sobre técnicas de interrogatório: um curso de tortura que certamente Burnier frequentou. Entre outros crimes ele é acusado de ter mandado matar o educador Anísio Teixeira.

O golpe de 1964 no Brasil foi articulado pelos Estados Unidos. Isso está comprovado historicamente, desde que vieram a público neste país documentos do período, depois que passou o prazo em que legalmente podiam ser mantidos secretos. Entre estes documentos, há uma gravação de John Kennedy tramando com Lincoln Gordon, o embaixador estadunidense no Brasil, a deposição de João Goulart. Isso em 1962, menos de um ano após Jango Goulart assumir a presidência.

Outra característica importante do imperialismo no século XX foi a competição com a União Soviética.

Não vou discutir se a União Soviética foi também imperialista ou não. Para isso seria necessário examinar as relações econômicas entre os países do chamado mundo comunista o que foge do escopo deste trabalho. Mas é certo que a União Soviética exerceu o domínio 
sobre outros países, inclusive intervindo militarmente, como na Hungria (1956) e na Checoslováquia (1968).

O importante é assinalar que a consolidação da União Soviética como potência mundial, após a II Guerra Mundial gerou uma competição com os Estados Unidos, conhecida como Guerra Fria. Isso marcou o mundo por quase cinco décadas. Ao mesmo tempo forneceu uma poderosa justificativa ideológica ao imperialismo. Não se tratava mais de levar a civilização a povos atrasados, mas de defender o "mundo livre" do comunismo ateu e repressor.

$\mathrm{O}$ anticomunismo foi largamente utilizado no golpe de 64 no Brasil, com importante apoio do conservadorismo católico. Nas mobilizações que antecederam o golpe, senhoras marchavam pelas ruas com rosário na mão, clamando a Deus que livrasse o país do comunismo. $\mathrm{O}$ anticomunismo estava na moda. $\mathrm{O}$ estranho é que ele tenha reaparecido no golpe de 2016 contra o PT, 25 anos depois do colapso da União Soviética. Isso mostra a força dessa justificativa, a ponto de ser utilizada até mesmo quando já não faz mais sentido.

\section{O imperialismo no século XXI}

Os golpes militares, como o do Brasil, começaram a entrar em declínio no final dos anos 70. Gradativamente os militares alinhados com os Estados Unidos foram deixando de ser os principais protagonistas na domesticação de seus países. Sociedades mais complexas, a popularização e generalização das tecnologias da informação e o fracasso das ditaduras anteriores tornam mais difícil mobilizar apoio popular a um golpe militar e, sobretudo, as dificuldades em depois controlar um grande país só na base da repressão e censura. Para um quadro mais complexo, o imperialismo precisava construir instrumentos de intervenção mais sofisticados, cultivar novos aliados internos e criar uma nova justificativa ideológica.

Novos métodos de intervenção indireta começaram a nascer nas chamadas revoluções coloridas nos países ex-comunistas. Há vários trabalhos acadêmicos analisando essas revoluções, um dos quais vem da Faculdade de Economia da Universidade Federal do Rio 
Grande do Sul ${ }^{1}$. A autora, Carolina Scherer, levantou dados importantes sobre a participação de organizações dos Estados Unidos no financiamento e treinamento de ONGs do Leste Europeu envolvidas nas revoluções coloridas. Entre essas organizações estão a USAID - Agência de Cooperação Internacional do Governo Estadunidense -, a Open Society do bilionário George Soros e o International Republican Institute ligado ao Partido Republicano.

O ponto de partida para o desenvolvimento dos novos métodos de intervenção foi o manual de ações não-violentas, criado por Gene Sharp, um professor da Universidade de Massachusetts. Na primeira das revoluções coloridas, a da Sérvia, em 2000, os Estados Unidos investiram 80 milhões de dólares, uma bagatela para derrubar um governo. A Alemanha também colocou dinheiro na empreitada. $\mathrm{O}$ principal beneficiário foi a ONG Sérvia OTPOR. Parte de seus membros foi treinada nos Estados Unidos nos métodos de ação de Gene Sharp, no uso sofisticado das redes sociais e das tecnologias de informação em geral.

Essa mesma OTPOR vai depois treinar organizações congêneres na Geórgia, Azerbaijão, Bielo-Rússia e Armênia, que igualmente tiveram suas revoluções coloridas, nem todas bem-sucedidas. Mais tarde, um braço da OTPOR vai aparecer no Egito, treinando organizações envolvidas na primavera árabe.

Faço um parêntesis para afirmar que, de maneira nenhuma, estou defendendo os governos atacados nas revoluções coloridas ou na primavera árabe. Em muitos desses casos o que houve foi que movimentos legítimos foram capturados por grupos financiados e treinados pelos Estados Unidos. Isso também vimos no Brasil, em 2013, quando os protestos contra o aumento das passagens de ônibus acabaram nas mãos de grupos de direita, tendo a pauta desviada para o antiPT, anti-movimentos sociais, anti-esquerda e depois para o golpe contra a presidenta Dilma Roussef. O que aconteceu no Brasil de 2013 foi a aplicação do mesmo modus operandi utilizado nas revoluções coloridas.

\footnotetext{
${ }^{1}$ Revoluções coloridas na Sérvia, Geórgia, Azerbaijão e Bielorrússia (2000-2006): promoção à democracia ou mudança de Regime? Porto Alegre, 2015, disponível em < $\underline{\text { https://www.lume.u- }}$ $\underline{\text { rgs.br/handle/10183/140511> }}$
} 
Examinemos agora os novos aliados internos do imperialismo.

No aparato institucional dos países visados os militares não são mais os principais pontos de apoio, mas nem por isso deixaram de ser cortejados pelos Estados Unidos. Tanto assim que a Escola das Américas está viva e forte, agora com outro nome e em outro local. Mudou-se do Panamá para a Geórgia. Pode-se dizer que os militares hoje compõem um time reserva, pronto para entrar em campo em fases mais agudas de um golpe, quando soluções de força bruta se tornam necessárias.

Entre os novos alvos prioritários, os principais são as forças policiais (que também frequentavam e frequentam os cursos da Escola das Américas) e o aparato Judicial. No caso das polícias, as ligações se estabelecem, sobretudo, através de cursos organizados pelo FBI e pelo DEA, agência encarregada do combate ao tráfico de drogas. No Brasil tem havido também dinheiro mandado direto para a Polícia Federal, em geral disfarçado de financiamento para operações de combate ao narcotráfico.

Já o Judiciário tem sido cooptado através de seminários de treinamento dos quais participam juízes e promotores. Recentemente o Wikileaks revelou um documento interno do governo estadunidense, com detalhes do Projeto Pontes, voltado ao treinamento de juízes e promotores da América Latina. Nesse documento, datada de 2009, os organizadores do seminário sugerem um treinamento mais aprofundado direcionado a Curitiba, São Paulo e Campo Grande. Outro método de cooptação são as palestras remuneradas que estrelas do Judiciário latino-americano proferem nos Estados Unidos. O juiz Sérgio Moro, de Curitiba, que comanda a "Operação Lava Jato", tem sido um dos palestrantes mais frequentes.

O terceiro aspecto nessa trilogia das novas formas de intervenção do imperialismo é a justificativa ideológica.

Nesse ponto, até agora não se tem algo tão unificador como foi o anticomunismo. Na falta de coisa melhor, adotam-se justificativas diferentes para cada país. Em uns é combate ao terrorismo. Em outros é a luta contra ditaduras. E em outros ainda é o combate à corrupção. Realmente, o anticomunismo era mais eficiente, pois com ele era possível justificar as ditaduras mais sanguinárias, as alianças mais estranhas. No entanto, é difícil conciliar a luta contra o terrorismo e a alian- 
ça com grupos ligados à Al-Qaeda, como os Estados Unidos fizeram na Síria, ou a destruição de um país em nome do combate a uma ditadura, como aconteceu na Líbia, ou ainda a entrega do poder a uma quadrilha de ladrões em nome do combate à corrupção, como aconteceu no Brasil.

\section{A sofisticada guerra híbrida no Brasil}

Nos 16 anos que separam a primeira revolução colorida, a da Sérvia, e o golpe contra Dilma Roussef no Brasil, as formas de intervenção do imperialismo evoluíram muito, até se transformar no que está sendo chamado de Guerra Híbrida. Quem primeiro usou esse termo foi Frank Hoffman, um especialista em estratégias militares, num estudo de 2007 para o Marines Corps, o corpo de fuzileiros navais dos Estados Unidos. Atualmente, passados mais de 10 anos desse primeiro estudo, Guerra Híbrida tem sido definida como o uso de métodos e apoios os mais variados contra um determinado país. Da mobilização de parte da população, como nas revoluções coloridas, aos drones e bombardeios aéreos, passando pela cooptação da mídia, do aparato judicial e policial do país visado, pelo apoio a grupos armados, intervenção eleitoral, fake news e o que mais for possível usar. É um tipo de estratégia que pode chegar à guerra total, mas a mobilização de forças hostis começa muito antes da guerra declarada.

A guerra civil na Síria, que começou com mobilizações populares, continuou com o apoio a grupos armados e chegou aos bombardeios aéreos é um exemplo de uma guerra híbrida completa.

No entanto, há quem cite o golpe no Brasil como exemplo mais sofisticado de guerra híbrida, sem chegar a conflito armado. Contou com manifestações de rua e com a chamada "Operação Lava Jato", de suposto combate à corrupção, conduzida por um juiz de confiança. Além disso, foi necessário ainda a compra de grandes parcelas do Congresso, o controle dos meios de comunicação, a cooptação do Supremo Tribunal Federal e, na sequência do golpe, para impedir a candidatura do ex-presidente Lula a mais um período presidencial, foi fundamental a atuação de três juízes do tribunal de apelação de Porto Alegre. Aparentemente, a guerra híbrida contra o Brasil não terminou, podendo ainda entrar em cena a força bruta dos militares, que o 
imperialismo nunca deixou de cortejar. Tudo vai depender dos rumos que o processo político tomar.

Certamente teremos que esperar outros 50 anos para que os historiadores tenham acesso aos documentos oficiais sobre o papel dos Estados Unidos no golpe de 2016. Mesmo sem esses documentos secretos, já temos uma série de informações sobre a linha de ação do imperialismo no golpe.

Primeiro, examinando os métodos utilizados, alguns deles muito semelhantes ao que se viu nas revoluções coloridas. Outro dado são as ligações com o dinheiro dos Estados Unidos de grupos de direita do Brasil que tiveram papel importante nas manifestações contra Dilma Roussef. O pouco que se sabe por enquanto é que o MBL (Movimento Brasil Livre) é financiado pelo Instituto Charles Koch, mantido pela família Koch, uma das mais ricas dos Estados Unidos, e que membros do MBL têm recebido treinamento da Students for Liberty, uma ONG com atuação internacional, que tem presença marcante em países cujos governos os Estados Unidos desejam derrubar. Em 2013 e 2014, essa organização ajudou a organizar protestos contra o governo da Ucrânia. Na Venezuela atua há muito tempo e tem sólidas ligações com organizações estudantis anti-chavistas.

Mais importante do que isso são os indícios de ligações da Operação Lava Jato com os órgãos de segurança dos Estados Unidos. Com certeza não foi a prisão do doleiro Alberto Youssef que levou à descoberta do enorme volume de informações que a chamada "força tarefa" da Lava Jato levantou no início da operação, antes de ter acesso à "mina de ouro" dos acordos de "delação premiada"

Seria igualmente ingênuo acreditar na explicação dada para a descoberta do chamado "Departamento de Propina" da construtora Odebrecht. O esquema da Odbrecht para repassar propina era sofisticadíssimo. Eles compraram um banco no exterior para isso. $\mathrm{O}$ dinheiro passava por um emaranhado de intermediários e contas em outros bancos até chegar ao destinatário final. Na versão oficial, esse sistema foi descoberto porque uma secretária levou para casa as pastas do esquema. Essa secretária começou a ser investigada sabe-se lá por que e as tais pastas caíram na mão da Polícia Federal.

Parece claro que muito do que foi descoberto pela Lava Jato, antes dos grandes acordos de deleção premiada, têm como fontes pri- 
márias órgãos como FBI, Departamento de Justiça e Departamento de Tesouro dos Estados Unidos. Essas agências governamentais realmente têm instrumentos para rastrear dinheiro em esquemas complexos como o da Odebrecht. E não se pode esquecer da NSA e seu gigantesco sistema de espionagem eletrônica que Edward Snowden denunciou.

Para encerrar esse tópico, algo sobre o papel do PSDB, partido do ex-presidente Fernando Henrique Cardoso, e sobre como as eleições nos Estados Unidos minaram a hegemonia deste partido no bloco golpista.

Não é novidade que o PSDB representa no Brasil os interesses do capital financeiro internacional, como vários pesquisadores já demonstraram $^{2}$, tendo jogado papel central no impeachment da presidenta Dilma Roussef. Os peessedebistas funcionaram como núcleo intelectual do golpe, passando a ocupar funções estratégicas no governo. A base dessa força eram suas conexões internacionais, sobretudo através do ex-presidente Fernando Henrique Cardoso, que nos Estados Unidos tem relações estreitas com os Clinton (o ex-presidente Bill Clinton e a senadora Hillary Clinton) que dominam o Partido democrata.

Os Clinton são os grandes fornecedores de recursos para as campanhas eleitorais do Partido Democrata, graças a suas ligações com Wall Street. Ou seja, através dos Clinton, o capital financeiro controla o Partido Democrata e, através de FHC, controla o PSDB. Hillary Clinton como secretária de Estado, foi responsável pela política externa dos Estados Unidos até 2013, quando já se articulava o golpe no Brasil. Ao deixar o governo Obama para se candidatar à presidência, seu sucessor foi um homem dos Clinton, John Kerry.

Foi nesse cenário que a preparação do golpe no Brasil se acelerou, cabendo a Fernando Henrique Cardoso a função de ponte entre a elite neoliberal brasileira e o Departamento de Estado. Consumado o golpe, o PSDB passou a ter papel fundamental, funcionando como fiador do governo Temer nos Estados Unidos.

\footnotetext{
${ }^{2}$ É o caso do professor Armando Boito, da Unicamp. Desse autor ver "Reforma e Crise Política no Brasil”, Editora da Unicamp, 2018
} 
O que não estava previsto era a derrota de Hillary Clinton na campanha eleitoral de 2016.

Quem descreve muito bem as consequências para o Brasil dessa reviravolta eleitoral é o professor José Luís Fiori, da Universidade Federal do Rio de Janeiro. Para ele, a vitória de Donald Trump levou a uma "surpreendente implosão e desmontagem do bloco golpista no Brasil”, pois sem contar mais com suas conexões no Departamento de Estado, o PSDB deixou de ser uma peça fundamental do governo Temer. O resultado foi que o núcleo intelectual do golpe perdeu poder, viu seu espaço reduzir-se, com o governo caindo de fato "nas mãos de um grupo da segunda divisão, de baixíssimo nível intelectual, inteiramente despreparado para governar o Brasil”, conclui Fiori ${ }^{3}$.

A cronologia dos fatos parece dar razão a Fiori. De farto, após a mudança de governo nos Estados Unidos o que se viu no Brasil foi uma batalha pelo poder no seio das forças antes unidas no golpe. Temer, cada vez mais atacado por "fogo amigo", via parte de seu grupo saindo do governo direto para a cadeia e ele próprio tendo que se submeter ao mais rasteiro fisiologismo do Congresso para não ser apeado do poder. Ou seja, com Trump, o imperialismo ficou temporariamente sem diretrizes claras com relação ao Brasil e isso, circunstancialmente, impediu o aprofundamento do golpe. Certas medidas que claramente estiveram na agenda do golpe, como a cassação do registro do Partido dos Trabalhadores ou o adiamento das eleições, não foram levadas adiante unicamente por conta do esfacelamento do bloco golpista.

\section{A dimensão geopolítica do golpe}

Muito se falou que o interesse dos Estados Unidos era se apoderar das riquezas do Brasil, particularmente do petróleo descoberto na camada marítima conhecida como pré-sal, além de destruir as grandes empresas brasileiras que competiam no mercado internacional. Teria sido este o principal motivo externo que levou ao golpe.

\footnotetext{
${ }^{3}$ Entrevista a Eleonora Lucena e Rodolfo Lucena, disponível em http://tutameia.jor.br/fioriponto-de-partida-e-a-libertacao-de-lula (acessada em 3/8/2018)
} 
O que aconteceu com a Embraer parece ir nessa linha. Tratase da venda para a norte-americana Boeing de uma empresa brasileira, a Embraer, que se destacava como uma das maiores competidoras no mercado internacional de jatos de porte médio.

No entanto, no caso do pré-sal, os fatos não foram na mesma direção. Os compradores de parcelas do pré-sal, vendidas nos dois primeiros anos após o golpe, foram empresas do Reino Unido (Shell e BP), da França (Total) e mais uma empresa da Noruega, uma da Espanha, uma do Catar e até mesmo uma da China. Nenhuma empresa estadunidense comprou nada no pré-sal. Nem mesmo a petroleira da família Koch, que financia o MBL.

Mais estranho ainda é o que tem acontecido na construção pesada Brasileira, até recentemente dominada por grandes conglomerados empresariais, com expressiva atuação no mercado Internacional. Quem vem se beneficiando da crise e encolhimentos das construtoras perseguidas pela Lava Jato são as construtoras Chinesas. Estão se beneficiando na América Latina, na África, (sobretudo em Angola, onde a Odebrecht tinha negócios importantes) e certamente estão de olho no mercado brasileiro de obras públicas.

Como explicar essa contradição? Certamente, parte da explicação está no entrelaçamento da economia mundial, acentuado pela financeirização generalizada, que faz surgir grandes conglomerados a partir dos quais os laços das empresas com seus países de origem praticamente se dissolvem. Esse tema será melhor tratado no tópico seguinte deste artigo.

Há, porém, outro aspecto a considerar: a dimensão geopolítica do golpe. De fato, basta lembrar o que foi descrito na parte inicial deste artigo para se perceber que aos Estados Unidos seria impensável a existência nesta parte do mundo de um país com desenvolvimento econômico autônomo, capaz de se tornar poderoso e de, no futuro, vir a desafiar a hegemonia norte-americana. Para não esquecermos as lições da História é importante recordar a doutrina do destino manifesto, o assalto ao México, as dezenas de intervenções na América Latina.

No caso do Brasil atual, com a descoberta do petróleo no présal, o país havia encontrado um modelo de desenvolvimento econômico independente e estava implantando esse modelo. Consistia em 
aproveitar a renda do pré-sal para desenvolver outros ramos da economia nacional. De um lado, gradativamente produzindo no país tudo o que fosse necessário para a exploração, transporte, refino e distribuição do petróleo do pré-sal. De plataformas marítimas e navios a tubulações para o transporte de combustíveis e uma infinidade de outros produtos e serviços. Este era o sentido da exigência de conteúdo nacional para as compras da Petrobras, a partir do qual nasceu uma importante indústria naval, que agora está liquidada porque as petroleiras do pré-sal podem comprar navios e plataformas marítimas no exterior.

A renda do pré-sal também passou a permitir financiamento maciço do BNDES (Banco Nacional de Desenvolvimento Econômico e Social) para o fortalecimento de algumas empresas, que ganharam musculatura para competir no exterior de igual para igual com grandes multinacionais. Assim cresceram a Friboi, a Odebrecht e outras empresas, especialmente da área de construção pesada.

Além disso, o Brasil estava começando projetos de cunho militar, como a construção de submarino nuclear e de aviões de caça, estes com tecnologia repassada pela Suécia, Aliás, o projeto do submarino nuclear estava a cargo de um braço da Odebrecht e o dos aviões de caça cabia à Embraer, duas das empresas alvo do golpe.

Finalmente, o país tinha espaço de destaque no cenário internacional e participava de uma articulação capaz de se constituir em um novo polo de poder, em contraposição aos Estados Unidos. Tratase dos BRICS, bloco envolvendo Brasil, Rússia, Índia, China e África do Sul.

\section{O imperialismo sem pátria e a pátria do imperialismo.}

O professor Ladislau Dowbor titular de pós-graduação na Economia da PUC de São Paulo, publicou em 2017 um livro muito interessante sobre a financeirização global. Ele descreve como a economia mundial hoje está dominada por gigantescos conglomerados que mesclam redes de indústrias, cadeias de comércio e serviços e empresas que negociam, em volumes imensos, commodities como petróleo, soja, minério de ferro.

Esses conglomerados têm no seu núcleo central grandes bancos que formam verdadeiros tentáculos pelo mundo todo, muitas ve- 
zes se entrelaçando entre eles. Daí o título do livro: "A Era do Capital Improdutivo"4.

A ideia central do livro é que esses conglomerados gigantescos têm hoje mais poder econômico do que países tomados individualmente. Isso não é novidade. A novidade é que ele traz dados de pesquisa e nos dá uma boa dimensão disso, em termos de dinheiro, de extensão dos tentáculos desses polvos pelo mundo, de capacidade de manipular a economia mundial e de impor as políticas que desejem aos países mais poderosos do mundo. Essa dimensão é bem maior do que habitualmente se pensava.

Grande parte do poder dessas estruturas empresariais advém daquilo que o autor define como controle em rede, um emaranhado de ligações entre esses gigantes, uma teia incompreensível em que uns detém parte da propriedade dos outros (e os outros da propriedade dos uns). A partir desse controle em rede, as 28 maiores instituições financeiras do mundo dispõem de um capital de 50 trilhões de dólares, várias vezes o produto bruto dos Estados Unidos, que é da ordem de 15 trilhões de dólares.

É a inexorável concentração do capital, cada vez maior, como Marx previra no século 19, agora em dimensões planetárias. Naturalmente, isso explica o fato de os Estados Unidos promoverem um golpe no Brasil, mas os principais frutos desse golpe terem sido colhidos por empresas com sede em outros países. É o imperialismo sem pátria, cujos interesses econômicos não mais se identificam com países tomados individualmente.

No entanto, seria errôneo deduzir daí que o país hegemônico do imperialismo, sua pátria por assim dizer, não tem interesses e objetivos particulares, que o diferenciam e o contrapõem aos demais países. Bastaria um exame superficial do cenário mundial para se perceber diferentes interesses nacionais em contraposição, que vão de simples disputas comerciais ao enfrentamento aberto, incluindo mobilizações militares. Essas disputas e enfrentamentos têm se acirrado cada vez mais nos últimos anos, num crescente processo de polarização, contrapondo de um lado os Estados Unidos e, do outro, a aliança en-

\footnotetext{
${ }^{4}$ A era do capital improdutivo - A nova arquitetura do poder, sob dominação financeira, sequestro da democracia e destruição do planeta”. Co-edição Outras Palavras e Autonomia Literária. São Paulo 2017.
} 
tre China e Rússia secundada em graus diferentes pelos países que compõem o chamado BRICS.

Pelo menos desde 2009 cresceu e se aprofundou a articulação entre os países do BRIC. Nele, até antes do golpe, o Brasil tendia a aparecer como terceira força, depois de China e Rússia. O motor econômico dos BRICS tem estado na China, segunda maior economia do mundo, em vias de se tornar a primeira e contando com a proteção do poderio militar russo.

A China, o mais novo membro do clube de países imperialistas, está hoje em todo mundo. Compra terras e investe em infraestrutura na África. Planeja a construção de um canal na Nicarágua ligando os oceanos Atlântico e Pacífico. Com a Rússia, construiu um gigantesco oleoduto que traz petróleo e gás russos para território chinês. Está se lançando em um ambicioso projeto, de dimensões planetárias, a chamada Nova Rota da Seda, que terá trens de alta velocidade ligando a China à Europa, portos modernos e novas rotas marítimas ligando a costa da Ásia à África, depois chegando à Europa e às Américas (pelo Atlântico e pelo Pacífico).

Para se contrapor à China e seus parceiros, os Estados Unidos lançaram dois projetos de integração econômica, a Parceria Transpacífica, com países dos dois lados do Oceano Pacífico, mas excluindo China e Rússia, e a Parceria Transatlântica, entre Estados Unidos e a União Europeia. A Parceria Transpacífica chegou a ser assinada, mas Trump caiu fora. Já o tratado com a União Europeia até hoje não entrou em vigor.

Em contrapartida, a partir de 2009, quando Hillary Clinton assumiu o Departamento de Estado, os Estados Unidos se tornaram cada vez mais agressivos militarmente. Começaram com provocações contra a Rússia no Leste Europeu que evoluíram para a crise na Ucrânia e continuaram na guerra civil da Síria. Ao mesmo tempo há um aumento significativo da presença militar estadunidense na Ásia, claramente voltada contra a China.

Enfim, há uma mobilização militar anti-russa e anti-chinesa que não combina com o entrelaçamento da economia mundial, aí incluindo China e, em menor escala, a Rússia. O que seria essa tensão militar? Manifestação de disputas inter-imperialistas? E o que se pode entender por "disputas inter-imperialistas"? Que países estão no cami- 
nho da confrontação militar porque alguns nós dessa entrelaçada rede burguesa planetária estão brigando uns com outros?

Em Marx, o Estado burguês existe para atender aos interesses da classe burguesa. Portanto, diferentes Estados imperialistas estariam se digladiando por procuração de suas respectivas frações da burguesia imperialista? Considero esta uma leitura simplista de Marx.

Levando em conta os aspectos históricos abordados neste capítulo e, sobretudo, o que se pode enxergar atualmente no cenário internacional, arrisco-me a formular a hipótese de que vivemos um período ao qual estão presentes dois modos de imperialismo. Um é o imperialismo de Estados poderosos do qual os Estados Unidos são sem dúvida um polo, sendo o outro polo o imperialismo chinês associado à Rússia. Um segundo modo é o imperialismo do capital financeiro e sua rede planetária de conglomerados interligados, que é essencialmente sem pátria porque choca seus ovos em todo o mundo.

Esses dois modos de imperialismo em geral estão articulados e se complementam. Ou seja, o Estado imperialista é servidor da burguesia imperialista, como é de se esperar. Mas os dois têm contradições, que em certos momentos se aguçam. Assim sendo, estaríamos atualmente vivendo um momento de aguçamento dessas contradições, em que os interesses da burguesia imperialista se descolam do estado imperialista.

\section{O esgotamento capitalista e a ameaça fascista}

O que se pode esperar da evolução das forças imperialistas e de suas contradições? Sai o imperialismo dos EUA e entra o imperialismo chinês? Vamos assistir ao triunfo total do imperialismo sem pátria?

Estas são questões para as quais ainda não há resposta. No entanto, além delas é necessário formular outra questão, certamente mais básica. Qual a perspectiva do modo de produção capitalista? Há claros sinais de esgotamento deste modelo, o que naturalmente levaria ao esgotamento da organização imperialista do capital.

O geógrafo marxista David Harvey publicou recentemente um livro intitulado " 17 contradições e o fim do capitalismo" ${ }^{5}$. Apesar do

${ }^{5}$ Editado no Brasil pela Boitempo, São Paulo, 2016 
título, este livro não faz nenhuma profecia em relação ao fim do modo de produção capitalista. Pelo contrário, destaca a imensa resiliência do regime, sua enorme capacidade de se adaptar e se reinventar, como tem mostrado ao longo dos últimos 200 anos.

Por exemplo, com relação à crise do meio ambiente, que é uma das tantas causas de esgotamento do modo de produção atual, ele cita a grande capacidade do capitalismo de transformar qualquer coisa em negócio. Assim está fazendo com a degradação ambiental, o que não quer dizer que esses problemas sejam resolvidos satisfatoriamente.

A guerra, ao longo da História utilizada para resolver as crises econômicas cíclicas, é algo a que o sistema poderá voltar a recorrer. O rufar de tambores já vem prenunciando isso, com guerras limitadas se intensificando desde a primeira década do século XXI e o acirramento da corrida armamentista.

No entanto, o risco mais concreto e mais generalizado a que temos assistido nos anos mais recentes é a implantação de regimes protofascistas, que podem chegar a ações genocidas para eliminar populações excedentes. É algo a que o capitalismo sempre recorre quando se sente ameaçado, como foi nos anos 30 do século passado, quando se sentiu encurralado por uma dupla ameaça: a grande depressão e uma conjuntura pré-revolucionária. Isso pode estar acontecendo nos dias atuais em que mesmo sem conjuntura revolucionária, o esgotamento do modelo capitalista se coloca de forma cada vez mais clara.

Casos como o genocídio do povo rohingyas em Mianmar, ou a fúria assassina contra dependentes de drogas nas Filipinas podem ser mais do que situações isoladas em países distantes. Precisam ser vistos num quadro mundial de avanço da direita xenófoba em países ditos desenvolvidos, a exemplo dos Estados Unidos, Itália, Hungria, Polônia, nações onde a violência contra o estrangeiro gradativamente tende a se estender aos nacionais. Nesse panorama enquadra-se igualmente o crescimento da violência contra as populações empobrecidas da África, Ásia e América Latina.

Naturalmente, há a alternativa da revolução social, que neste momento não está no horizonte, mas que o aprofundamento da crise do capitalismo pode colocar na ordem do dia. No entanto, o modo de produção capitalista não vai desaparecer unicamente por conta de suas 
contradições e a revolução social não vai nascer do nada. Para que ela aconteça é necessário organização, é necessário projeto, convencimento e mobilização social, que por enquanto ainda não existem. Os processos históricos têm uma dinâmica própria, independente das pessoas, mas o rumo que tomam depende das pessoas.

\section{Post scriptum - A operação Bolsonaro}

Uma atualização deste artigo, agora considerando as eleições de outubro de 2018 no Brasil, parece reforçar a ideia de que nosso país está sendo alvo de uma sofisticadíssima guerra híbrida. Começou com um golpe judicial-parlamentar-midiático, que levou à implantação de um governo estreitamente ligado aos interesses tanto do imperialismo, quanto de amplos setores da burguesia brasileira. Para atender a esses interesses, em dois anos foram feitas "reformas" que implicam, entre outras consequências, redução de salários, retomada das privatizações, desmonte da política para o petróleo e entrega a corporações de grandes parcelas do orçamento público em áreas como educação e saúde.

No entanto, como dar continuidade a esse processo no longo prazo, mantendo-se as instituições democráticas, com eleições regulares e alternância no poder? Vários indícios levam à conclusão que uma nova etapa do golpe já estava planejada para ser colocada em prática nas eleições de 2018. O roteiro, que poderia variar conforme o desenrolar dos acontecimentos, acabou se afunilando na direção de algo que se poderia chamar de "operação Bolsonaro".

A primeira fase foi a viabilização eleitoral de um candidato de perfil autoritário, o ex-capitão do exército Jair Bolsonaro. Esse deputado, que se notabilizara por declarações nacionalistas e contrárias às privatizações do ex-presidente Fernando Henrique Cardoso, surpreendentemente apresentou-se como candidato com um programa neoliberal ao extremo. Ao mesmo tempo, com um discurso de acirrado conservadorismo nos costumes e extremamente repressivo em matéria de segurança pública, procurou atender tanto às preocupações do fundamentalismo religioso, quanto aos medos de amplas camadas da população afetadas pelo crescente banditismo nas cidades brasileiras. 
Suas frases raivosas, muitas vezes ofensivas, receberam ampla cobertura da mídia, o que acabou servindo para ampliar sua popularidade.

Porém, sua campanha presidencial só teve sucesso porque contou com o uso massivo de redes sociais para divulgar fake news específicas, para diferentes públicos, selecionados conforme as convicções de cada grupo. Não é mera coincidência que esse mesmo sistema tenha sido utilizado pelo atual presidente dos Estados Unidos. De fato, o diretor-executivo da campanha de Trump, Steve Bannon, foi estrategista de Bolsonaro, como é de amplo conhecimento. Enquanto isso, a anunciada ofensiva dos tribunais eleitorais contra as fake news não passava de mais uma fake news.

Fato marcante dessa estratégia ocorreu uma semana antes do primeiro turno das eleições. Majoritariamente odiado pelo eleitorado feminino por suas declarações misóginas e seu palavreado ofensivo, o crescimento de Bolsonaro nas pesquisas levou à organização de gigantescas manifestações contra ele lideradas por mulheres em todo o país, no sábado 29 de setembro. Foram, provavelmente, as maiores manifestações contra o fascismo já realizadas no país que tiveram como resposta, no dia seguinte, manifestações a favor de Bolsonaro infinitamente menores. Parecia que a derrota eleitoral do ex-capitão estava selada. Surpreendentemente, pesquisas realizadas após essas manifestações indicaram exatamente o contrário: as intenções de voto em Bolsonaro haviam crescido e, mais surpreendente ainda, crescido também entre as mulheres.

A explicação para o fenômeno não tardou. De um lado, a grande mídia televisiva ou ignorou a mobilização das mulheres, ou as apresentou junto com as manifestações pró-Bolsonaro, dando o mesmo peso às duas. Por outro, o que apareceu massivamente nas redes sociais foram montagens em que as manifestações antifascistas apareciam acopladas a imagens de mulheres profanando crucifixos, de gente de vermelho atacando quem vestia camiseta da seleção brasileira de futebol, de feministas semi-nuas e de famílias sendo insultadas. Contratos milionários, com empresas ditas "impulsionadoras de conteúdo”, fizeram com que essa narrativa predominasse.

Eleito Bolsonaro, o que se prenuncia é um típico governo protofascista, com uma agenda repressiva legitimada pelas urnas. Terá quatro anos para pôr em prática seu programa neoliberal e de restri- 
ção de direitos, mas o projeto certamente é de continuidade muito além desse prazo. Para tanto, contará com uma retaguarda de militares muito bem posicionada no ministério do novo governo. Se esse processo será barrado ou caminhará para uma ditadura escancarada dependerá das futuras relações de força.

O modelo de golpe aplicado no Brasil, complexo e sofisticadamente maleável, talvez já tenha sido transformado em manual para ser levado a outros países, tal como as fórmulas desenvolvidas para as revoluções coloridas e para os golpes em Honduras e Paraguai foram aqui utilizados. 



\section{II}

\section{A CRISE POLÍTICA E O PAPEL DA EDUCAÇÃO NA RESISTÊNCIA AO GOLPE DE 2016 NO BRASIL *1}

Dermeval Saviani

Ao ministrarmos na Faculdade de Educação da UNICAMP o Curso Livre de Extensão Universitária "O Golpe de 2016 e a Educação no Brasil” procuramos, serenamente, cumprindo o papel social da universidade, colocar à disposição dos interessados elementos analíticos par lhes permitir compreender os problemas enfrentados para além da visão comum e corrente propiciada tanto pelos meios de comunicação convencionais (televisão, rádio, jornais) como pelas redes sociais.

Na primeira aula tratei da crise política no Brasil em sua relação com a educação. Como ponto de partida da análise abordei a crise política atual. Num segundo momento, para situar o papel da educação indiquei a forma como a educação foi posta em posição estratégica na construção da democracia na sociedade moderna na qual ainda estamos vivendo. Feita essa caracterização abordei, por fim, o tema específico referente ao papel da educação na resistência e na transformação dessa situação de crise em que nos encontramos. No desenvolvimento desse roteiro me baseei no texto "A crise política no Brasil, o golpe e o papel da educação na resistência e na transformação", publicado no livro A crise da democracia brasileira (LUCENA; PREVITALI; LUCENA, 2017, p. 215-232). O referido texto foi organizado nos seguintes tópicos: 1. A crise política no Brasil atual; 2. A educação como exigência da construção da democracia na sociedade moderna; 3. O papel da educação na resistência e transformação da situação de crise em que vivemos atualmente no Brasil.

*DOI - 10.29388/978-85-53111-28-2-()-f.27-46

${ }^{1}$ Aula de Abertura do Curso Livre “O Golpe de 2016 e a Educação no Brasil”. 
Na primeira aula do Curso Livre "O Golpe de 2016 e a Educação no Brasil” desenvolvi esses três tópicos reproduzindo o conteúdo publicado no livro citado. Assim, para ter acesso ao que foi tratado nessa primeira aula os leitores poderão baixar no "site" da editora Navegado Publicações o e-book $\boldsymbol{A}$ crise da democracia brasileira e fazer a leitura do primeiro texto da III Parte denominada "O golpe parlamentar e seus impactos na educação brasileira”. A seguir, vou tratar sucessivamente de cada um dos três tópicos fazendo uma referência sumária ao conteúdo exposto na aula e apresentando novas abordagens da temática que se explicitaram ao longo de 2018, portanto, após a data de 15 de março, quando se iniciou o Curso Livre sobre o golpe de 2016 e a educação.

\section{A crise política no Brasil atual}

Comecei a análise mostrando que a crise política que se abateu sobre o Brasil foi justificada em nome do combate à corrupção fazendo acreditar que foi o PT que, ao chegar ao governo, instalou uma verdadeira quadrilha empenhada na apropriação privada dos fundos públicos. E mostrei, por meio de depoimentos como o do ex-presidente da Associação dos Delegados da Polícia Federal, Armando Coelho Neto e de Bresser-Pereira, que foi um dos mais importantes ministros do governo de Fernando Henrique Cardoso, do PSDB, que a verdade é bem outra. $\mathrm{O}$ erro do $\mathrm{PT}$ foi, ao assumir o governo, não ter tentado desmontar o esquema que já existia e do qual se serviam os partidos que chegavam ao poder. Ao contrário, para assegurar uma base de apoio no Congresso sem o que não conseguiria governar, o PT lançou mão do esquema que já se encontrava em funcionamento muito antes de ter surgido o Partido dos Trabalhadores.

No clima de ódio contra o PT incentivado com a insistência da mídia diariamente esmiuçando denúncias não comprovadas contra Dilma, Lula e o PT criou-se uma situação muito grave porque todas as instituições da República (Judiciário, Ministério Público, a própria Ordem dos Advogados do Brasil, as entidades empresariais, Parlamento, Partidos políticos, toda a grande mídia televisiva, escrita e falada) encontram-se conspurcadas e obcecadas com o único objetivo de destruir o PT e impedir Lula de voltar a se candidatar. E, para isso, não 
têm pejo em violar as normas jurídicas relativas aos direitos mais elementares, inclusive dispositivos constitucionais, desembocando no golpe parlamentar-jurídico-midiático desencadeado em 17 de abril na Câmara dos Deputados e consumado no Senado em 31 de agosto de 2016. Configurou-se uma situação muito perigosa porque está em curso uma onda fascista que vem se manifestando explicitamente com saudações nazifascistas e incitação ao armamento da população, como o fez o deputado Jair Bolsonaro, um ex-militar que pauta suas ações pela defesa da Ditadura Militar com homenagens aos torturadores da época da ditadura. É um quadro muito preocupante que nos faz lembrar da Alemanha das décadas de 1920 e 1930 com a ascensão de Hitler, apoiado pelo fanatismo que se apossou da população. Naquela situação também a Justiça se revelou draconiana com as ações da esquerda e complacente com a truculência da direita. Agora, no Brasil, está em curso iniciativas que, como observou o jurista Fábio Konder Comparato, deixa o Estado de Direito em frangalhos, com violações de normas constitucionais.

A caracterização da destituição de Dilma Rousseff, presidenta reeleita, como um golpe decorre do fato de que não foi cumprida a exigência constitucional da existência de crime de responsabilidade, único motivo legal que justifica o impeachment. Obviamente, os autores desse ato sempre negaram a existência do golpe argumentando que seguiram todo o ritual previsto, inclusive com a chancela do Supremo Tribunal Federal que presidiu a sessão do Senado que consumou o impeachment, conforme previsto na Constituição. Ocorre que o STF lavou as mãos sugerindo que a decisão cabe ao Senado Federal, órgão do Poder Legislativo que é autônomo, não cabendo ao Judiciário interferir. Nesse caso a pergunta inevitável é: se a decisão compete ao Poder Legislativo no uso de sua autonomia não cabendo ao Judiciário interferir, por que, então, a Constituição determinou que a Sessão do Senado fosse presidida pelo Presidente do STF? Em se tratando de competência exclusiva do Poder Legislativo caberia, simplesmente, ao Presidente do Senado presidir a sessão assegurando, na forma do Regimento da Casa, a decisão dos senadores. Sendo o Presidente do STF a presidir a sessão, isso indica, obviamente, que, ao enfeixar nas mãos do dirigente máximo do Poder Judiciário a condução da sessão, o que se pretendia era assegurar que a decisão se desse rigo- 
rosamente dentro do disposto na Constituição. E o papel do Presidente do órgão guardião da Constituição investido da função de presidir a sessão não tinha outro sentido senão garantir que a decisão não se desvirtuasse em razão dos interesses político-partidários, mesmos legítimos, que se fazem presentes no Parlamento.

Assim, com a conivência do Judiciário, representado pelo seu dirigente máximo, o presidente do Supremo Tribunal Federal, o golpe se consumou com a decisão do Senado Federal que, em sessão realizada no dia 31 de agosto de 2016, cassou o mandato presidencial de Dilma Vana Rousseff.

Agora, porém, após a autocrítica de Tasso Jereissati, tucano de alta plumagem, ex-presidente do PSDB, se ainda houvesse alguma dúvida quanto à existência do golpe, foi inteiramente dissipada. Em entrevista ao Jornal "O Estado de São Paulo" no dia 13 de setembro de 2018, o senador Tasso Jereissati que, além de ex-presidente do PSDB é presidente do Instituto Teotônio Vilela, que é o órgão de formação política do partido, confessou que o PSDB "cometeu um conjunto de erros memoráveis”. O primeiro foi, já no dia seguinte à eleição, contestar o resultado eleitoral. Disse ele que essa decisão contrariava a história e o perfil do partido que se pautava pelo respeito às instituições e à democracia reconhecendo que tal contestação foi um atentado contra a democracia. O segundo erro foi votar contra os princípios do próprio partido, de modo especial na economia, só para ser contra o PT. Reconheceu, assim, o boicote ferrenho que os parlamentares fizeram ao governo de Dilma com as pautas bomba provocando o caos e inviabilizando o governo para provocar sua queda. E o terceiro, que Jereissati classifica como o "grande erro" foi entrar no governo Temer. Fica, pois, caracterizado o golpe na avaliação de um dos principais dirigentes do principal partido de sustentação do governo ilegítimo, antipopular e antinacional instalado com o afastamento da presidenta reeleita e a consequente posse de Michel Temer na presidência da República.

Mas o que é preciso considerar é que não foi simplesmente um golpe episódico, ou seja, um ato anticonstitucional que substituiu o chefe de Estado que, a partir daí, passou a governar conforme as regras democráticas então vigentes. Não. Com o afastamento de Dilma Rousseff quebrou-se a institucionalidade democrática deixando de 
existir o Estado Democrático de Direito. E passamos a viver num Estado de exceção com uma sequência de atos discricionários abrindo margem a uma verdadeira escalada do arbítrio, num estado de golpe contínuo constituído por atos que se sucedem eivados de ilegalidade cometidos pelo Executivo, por parlamentares, pelo Judiciário e pela imprensa que vão desde as condenações sem provas até, às vésperas da eleição, a liberação de delação, a censura à imprensa na forma do impedimento de entrevistar Lula em contraponto à autorização de entrevista de Bolsonaro à TV Record no horário do debate dos candidatos à presidência da República.

Dando sequência a essa escalada do arbítrio o juiz de primeira instância, Sérgio Moro, liberou, há apenas seis dias das eleições em primeiro turno, denúncias da delação premiada de Antonio Palocci com o claro intuito de interferir nas eleições. Com efeito, a referida delação havia sido rejeitada pelo Ministério Público e o próprio juiz Moro reconheceu que não poderá levar tal depoimento em consideração no julgamento da ação penal. Mas liberou parte da delação, exatamente aquela em que aparece denúncia, sem qualquer prova, contra Lula e Dilma, evidentemente para interferir nas eleições prejudicando a candidatura do PT. E, de fato, analistas atribuem a essa liberação, amplamente difundida pela mídia e largamente utilizada na propaganda dos adversários, a onda pró Bolsonaro revelada pelas urnas na apuração do primeiro turno. E em plena campanha do segundo turno surge a notícia de que o Tribunal Regional Federal da $4^{\underline{a}}$ Região marcou para a quarta-feira 24 de outubro, quatro dias antes do segundo turno das eleições presidenciais, o julgamento do recurso do ex-ministro Antonio Palocci, condenado em 2017 por Sergio Moro a 12 anos e dois meses de prisão. É mais uma interferência indevida e ilegal do judiciário nas eleições visando a prejudicar a candidatura do PT. Ao favorecer a eleição de Bolsonaro a Justiça apostará na barbárie contra a civilização?

Em consequência do golpe nós voltamos a uma situação politicamente equivalente à ditadura que se abateu sobre nosso país entre 1964 e 1985. Naquele momento o golpe militar instalou um Estado de exceção governado pelos militares por 21 anos configurando uma situação que vitimou também outros países da América Latina. Esses 
foram golpes de força que recorreram às Forças Armadas com o apoio da CIA, a Agência Central de Inteligência dos Estados Unidos.

Agora a estratégia mudou na direção da desestabilização seguida de destituição, por via parlamentar, de governos populares. Essa iniciativa vem sendo posta em prática em diferentes países, especialmente onde os Estados Unidos têm interesses econômicos ou politicamente estratégicos. Daí as mobilizações ocorridas em países como a Tunísia, Egito, Líbia (a chamada "primavera árabe”), assim como na Síria, Rússia e Ucrânia. Na América do Sul, após o Paraguai, os alvos imediatos são o Brasil e a Venezuela, não por acaso dotados de grandes reservas de petróleo, esboçando-se movimento semelhante na Bolívia e no Equador, sendo que na Argentina a vitória da direita nas eleições tornou desnecessário o recurso ao golpe jurídico-parlamentar.

Em entrevista recente à TV $247^{2}$ Pepe Escobar, um dos principais estudiosos de geopolítica e correspondente internacional que vive entre Paris, Londres, Bruxelas, Rússia, Irã e China, traçou interessante análise do tabuleiro geopolítico atual.

Segundo sua análise a atual tragédia brasileira pode ser explicada pelo declínio do império americano: "[...] o Brasil foi alvo de uma guerra não convencional, a chamada guerra híbrida ${ }^{3}$, que prescinde de tanques e canhões, mas conta com o apoio de elementos internos, estrategicamente colocados no Poder Judiciário, para realizar o trabalho que antes era feito pelos militares" [...], cujo resultado não foi somente a derrubada do governo, mas a desestruturação completa do país.

Escobar considera que o Brasil alcançou protagonismo internacional tendo atingido o auge com o chanceler Celso Amorim no governo do ex-presidente Lula. Eis a razão da expressão de Obama "você é o cara" dirigindo-se a Lula. Esse protagonismo que, pela articulação dos chamados BRICS, a aliança dos cinco grandes países emergentes Brasil, Rússia, Índia, China e África do Sul, romperia o domínio unipolar americano, pôs em movimento a estratégia da "guerra híbrida", conceito criado por think tanks (grupos de reflexão geopolítica) americanos. Segundo Escobar, na guerra híbrida "o fator

2 Disponível em: <https://www.brasil247.com/pt/247/brasil/347245/Pepe-Escobar-o-Brasil-éalvo-de-uma-guerra-híbrida.htm> acesso em 09 nov. 2018

${ }^{3}$ Para um entendimento mais aprofundado do conceito de "guerra híbrida" os leitores poder recorrer ao livro Guerras híbridas: das revoluções coloridas aos golpes, de autoria de Andrew Korybko (2018). 
militar não é o mais importante, mas a junção de fatores judiciários, midiáticos, parlamentares, políticos e empresariais” seguidos de longa investigação criminal, tarefa que, no caso do Brasil, vem sendo cumprida pela Lava Jato.

Considerando a possibilidade de que, com governos populares, o Brasil viesse a se elevar à condição de potência internacional, os Estados Unidos decidiram mover a "guerra híbrida” para desestabilizar o governo brasileiro. Assim, o golpe começou a ser construído, segundo Pepe Escobar, a partir da espionagem realizada pela NSA, a Agência de Segurança Americana, contra Dilma e a Petrobras. Aliás, a ação contra Dilma foi revelada pelos documentos secretos americanos divulgados pela WikiLeaks. Consumado o golpe, o Brasil voltou à condição de subserviência aos Estados Unidos entregando nossas riquezas à potência imperial sem qualquer contrapartida. Na vigência do atual governo nosso país vem se desmoralizando perante o mundo e perdendo totalmente o protagonismo internacional que vinha exercendo ao longo dos governos Lula e Dilma.

Como se vê, os processos contra Lula e a condenação sem provas se inserem "numa estratégia complexa de desestruturar o Brasil por dentro". Portanto, trata-se, sim, de perseguição política e não, como se quer fazer crer, de uma iniciativa de combate à corrupção. Como afirmou em entrevista disponível no Youtube o ex-presidente da Associação dos Delegados da Polícia Federal, Armando Coelho Neto, não se está lutando contra a corrupção. Se isso estivesse ocorrendo outras operações estariam em curso. A Operação Zelotes, por exemplo, resultou abafada porque nela estão envolvidos grandes personagens da política, grandes empresas e bancos, grupos de comunicação, à testa a Rede Globo, num grande escândalo intermediado pelo Banco HSBC que, por conta disso, acabou se retirando do país. Na própria Operação Lava-Jato as delações trouxeram à baila nomes do PSDB e de outros partidos que, no entanto, são blindados. Registre-se que o PSDB era um partido de centro que enveredou para a direita assumindo a defesa dos interesses externos, em especial dos Estados Unidos. A conclusão do ex-presidente da Associação dos Delegados da Polícia Federal é que o que está em curso não é uma luta contra a corrupção, mas uma guerra contra o PT. Essa guerra culminou com o impeachment de Dilma Rousseff apenas um ano e meio após sua pos- 
se como presidenta reeleita. Diante desse fato podemos concluir que o Estado Democrático de Direito deixou de existir no Brasil, vitimado por um Golpe de Estado jurídico-midiático-parlamentar.

Estamos, pois, vivendo um enorme retrocesso político que arrisca ser legitimado pelas urnas com a eleição de Bolsonaro num processo marcado por uma dupla fraude. A primeira foi a prisão de Lula numa condenação sem provas, impedindo sua candidatura quando as pesquisas eleitorais o colocavam em primeiro lugar na preferência dos eleitores. A segunda fraude foi a estratégia da campanha do ex-capitão planejada com a assessoria do marqueteiro de Trump, Steve Bannon, que espalhou largamente notícias mentirosas pelos diferentes dispositivos das redes sociais, entre os quais se destacou o WhatsApp. Conforme reportagem do Jornal Folha de S.Paulo de 18 de outubro de 2018, a campanha de Bolsonaro contratou empresas de disparos de mensagens em massa que, pelo aplicativo de mensagens instantâneas WhatsApp, espalharam notícias falsas contra a candidatura do PT em flagrante violação do artigo 222 do Código Eleitoral Brasileiro que define como "anulável a votação, quando viciada de falsidade, fraude, coação...".

\section{2) A educação como exigência da construção da democracia na sociedade moderna}

Apresentada a situação de crise que vivemos em consequência do golpe que vitimou a democracia brasileira, passei ao segundo momento da aula procurando caracterizar a emergência da educação como exigência da construção da democracia na sociedade moderna. Mostrei, então, como se constituiu a sociedade capitalista, a partir da sociedade feudal, evidenciando as relações sociais específicas do modo de produção capitalista: proprietários livres que se defrontam no mercado; de um lado, o capitalista que detém a propriedade dos meios de produção; de outro lado, o trabalhador (o proletário) que detém a propriedade somente de sua força de trabalho. Nessa condição eles entram em relação de troca e celebram "livremente" um contrato mediante o qual o capitalista compra a força de trabalho adquirindo, assim, o direito de se apropriar de tudo o que o trabalhador é 
capaz de produzir; e o trabalhador, por sua vez, vende sua força de trabalho em troca do salário que lhe permite sobreviver.

Essa nova forma de sociedade se consolida a partir da Revolução Francesa (1789) e se consuma com a derrubada da Comuna de Paris (1871), pois, no dizer de Gramsci, foi nesse momento que o novo, a ordem burguesa, triunfou ao mesmo tempo sobre o velho, o Antigo Regime, e sobre o novíssimo, a revolução socialista preconizada pelos trabalhadores. Nessa nova situação a burguesia se torna não apenas classe dominante, mas também classe hegemônica, uma vez que sua visão de mundo, o liberalismo, transforma-se em senso comum, passando a ser compartilhada pelo conjunto da sociedade. E a forma política posta em posição dominante nessa nova organização social é a democracia, entendida como o regime baseado na soberania popular. O soberano deixa de ser o rei e passa a ser o próprio povo. Mas, para exercer a soberania os membros da população precisam ser educados. A escola surge, então, como o grande instrumento de construção da ordem democrática difundindo-se a ideia da "escola redentora da humanidade" sob cuja égide desencadeia-se a campanha pela escola pública, universal, obrigatória, gratuita e laica viabilizada, em cada país, pela organização do respectivo sistema nacional de ensino.

Nesse novo contexto a educação assume uma função explicitamente política. A escola passa a ser entendida como um instrumento para transformar os súditos em cidadãos, portanto, um instrumento de participação política, a via efetiva para se implantar a democracia, o que, obviamente, era de interesse não apenas da classe dominante, mas também da classe dominada. Eis aí o caráter hegemônico da burguesia: seus interesses são expressos de modo a abarcar também os interesses das demais classes; a ideologia liberal se torna consenso. Isso, porém, não ocorre de forma linear, mas de maneira contraditória.

Se a participação política das massas configura um interesse comum a ambas as classes (dominante e dominada), ao se efetivar, acaba por colocá-las em confronto de vez que os interesses específicos de uma e outra são inconciliáveis em última instância. A expectativa dos representantes da classe dominante era que o povo, uma vez alfabetizado, apoiaria seus programas de governo. Isto, porém, não se deu. Depois da euforia iluminista em torno do lema da escola redentora da humanidade difunde-se nas primeiras décadas do século XX “a con- 
vicção de que apesar da alfabetização universal não resulta tão simples implantar, de verdade, as formas democráticas de governo”. Daí a percepção de que "nem sempre 'um povo ilustrado escolhia bem os seus governantes' e que se davam casos de povos instruídos, alfabetizados, que, apesar de tudo, [...] seguiam a demagogos, aceitavam tiranos e caudilhos, e deixavam de lado os melhores programas de governo, que se lhes ofereciam em cartilhas bem impressas" (ZANOTTI, 1972 , p. 44). Ocorre que os tais "programas de governo" eram "os melhores" do ponto de vista dos interesses dominantes. As camadas dominadas não se identificavam com os referidos programas. Fica, assim, evidente que a sociedade moderna, ao mesmo tempo em que espera e exige da escola a formação para a democracia traduzida no objetivo da formação para o exercício da cidadania, inviabiliza essa tarefa impedindo a escola de realizá-la.

Mas então, como explicar essa situação paradoxal da educação que, em lugar de contribuir para a construção e consolidação da democracia torna essa tarefa praticamente impossível?

A resposta a essa pergunta encontra-se na própria estrutura da sociedade capitalista em que se defrontam no mercado proprietários aparentemente iguais, mas de fato desiguais, realizando, sob a aparência da liberdade, a escravização do trabalho ao capital. Instala-se a cisão entre a aparência e a essência, entre o direito e o fato, entre a forma e a matéria (ou o conteúdo).

Considerando que o trabalhador, se não vender sua força de trabalho ao capitalista, não terá como sobreviver, ele na verdade não tem escolha. Ou ele vende sua força de trabalho ou simplesmente vai morrer. Isso significa que, enquanto o capitalista é livre na aparência e na essência, de direito e de fato, formal e materialmente, o trabalhador é livre apenas na aparência, no plano do direito e no aspecto formal. Essencialmente, de fato e materialmente, ele é escravo. Com efeito, a força de trabalho não é um bem que o trabalhador possui e do qual pode dispor transferindo-o a outro e permanecendo integralmente ele mesmo, como ocorre com os bens que adquirimos e dos quais podemos nos desfazer sem afetar nossa integridade pessoal. A força de trabalho constitui o próprio corpo do trabalhador. Portanto, ao vendê-la ele está vendendo a si mesmo, o que significa que ele se converte em agente da própria escravidão. Assim estruturada, a sociedade 
burguesa contrapõe o homem enquanto indivíduo egoísta e o homem enquanto pessoa moral, isto é, como cidadão abstrato. Por isso os direitos do cidadão são direitos sociais que cada indivíduo possuirá sempre em detrimento de outros. Eis como a sociedade burguesa faz com que todo homem encontre noutros homens não a realização, mas a limitação de sua liberdade.

Compreendemos, então, por que a escola pública universal, gratuita, obrigatória e laica, idealizada e realizada pela burguesia para converter os súditos em cidadãos, não tenha passado de um instrumento a serviço da emancipação política entendida como "a redução do homem, de um lado a membro da sociedade burguesa, a indivíduo egoísta independente e, de outro, a cidadão do Estado, a pessoa moral' (MARX, s/d., p.38). Eis como a proposta burguesa de educação básica, geral e comum esconde a divisão entre o homem real, reduzido ao indivíduo egoísta independente e o homem ideal, proclamado como pessoa moral, cidadão abstrato do Estado.

\section{3) O papel da educação na resistência e transformação da situa- ção de crise em que vivemos atualmente no Brasil}

Tendo caracterizado a relação entre educação e democracia no processo de consolidação da sociedade moderna perpassado por conflitos e contradições, passei, no terceiro momento da aula, a abordar o papel da educação na resistência ao golpe que provocou a ruptura da institucionalidade democrática e sua contribuição para a transformação da situação em que nos encontramos. Comecei, então, por mostrar que, do que foi exposto no tópico anterior, podemos concluir que a formação para o exercício da cidadania já pode ser considerada uma função clássica da educação escolar, pois vem sendo apregoada desde o início do século XIX. No entanto, no Brasil a descontinuidade da experiência democrática tem afastado periodicamente a discussão dessa questão.

Assim, se no período da ditadura militar a educação foi despojada de sua função de formação para a participação política, com a abertura política passou-se a discutir mais intensamente não apenas a questão da democratização da escola, mas também a importância da educação no processo de democratização da sociedade. Buscou-se, as- 
sim, recuperar a função clássica da educação enquanto formação para o exercício da cidadania contrapondo-se ao contexto do regime militar quando essa preocupação caíra no esquecimento ao se promover a despolitização da educação, definindo-se como seu papel principal a preparação funcional de recursos humanos para o mercado de trabalho. Mas essa tendência que vinha se desenvolvendo na direção da consolidação da democracia desde o início dos anos oitenta do século XX rompeu-se agora no Brasil com o desfecho do golpe jurídicomidiático-parlamentar que provocou a quebra da institucionalidade democrática liquidando o Estado Democrático de Direito.

$\mathrm{Na}$ atual crise a educação é desafiada duplamente: por um lado, cabe-lhe resistir, exercendo o direito de desobediência civil, às iniciativas de seu próprio abastardamento por parte de um governo que se instaurou por meio da usurpação da soberania popular sobre a qual se funda o regime político democrático. Por outro lado, cumpre lutar para transformar a situação atual debelando a crise e assegurando às novas gerações uma formação sólida que lhes possibilite o pleno exercício da cidadania tendo em vista não apenas a restauração da democracia formal, mas avançando para sua transformação em democracia real. Ou seja, nos termos formulados por Marx em A questão judaica, precisamos ir além da "emancipação política" realizando a "emancipação humana”, o que se identifica com o objetivo da revolução socialista.

No entanto, exatamente quando se alimentou a esperança de algum avanço mais significativo com a aprovação do novo PNE, que finalmente incorporou a meta de $10 \%$ do PIB para a educação, reivindicada desde a década de 1980 por ocasião da Constituinte, e com a destinação de parcela considerável dos recursos do pré-sal para a educação, sobreveio o golpe e estamos diante de um retrocesso não de anos, mas de décadas.

Tal retrocesso incide sobre vários aspectos, a começar pelo Plano Nacional de Educação (PNE), aprovado pela Lei n. 13.005, sancionada em 25 de julho de 2014, uma vez que as medidas pós-golpe já o tornaram letra morta, pois várias de suas metas já venceram sem serem atingidas e as que ainda não venceram não têm mais a mínima chance de se viabilizar. Vejamos: a) metas já vencidas: Meta 1 (Educação Infantil) - universalizar, até 2016, a educação infantil na pré-escola 
para as crianças de 4 a 5 anos de idade; Meta 3 (Ensino Médio) - universalizar, até 2016, o atendimento escolar para toda a população de 15 a 17 anos de idade; Meta 18 - assegurar, no prazo de 2 anos (portanto, até 2016), a existência de planos de carreira para os profissionais de todos os sistemas de ensino; Meta 19 - assegurar condições, no prazo de 2 anos (portanto, também até 2016) para a efetivação da gestão democrática; b) metas a vencer: Meta 2 - universalizar o ensino fundamental de 9 anos para toda a população de 6 a 14 anos até o último ano de vigência deste PNE (2024); Meta 4 - universalizar, para a população de 4 a 17 anos com deficiência, transtornos globais do desenvolvimento e altas habilidades ou superdotação. Essa meta trata, portanto, da educação especial e, como não menciona a data, considera-se o final da vigência do Plano, ou seja, 2024, como prazo para ser atingida; Meta 20 - ampliar o investimento público em educação pública de forma a atingir, no mínimo, o patamar de 7\% do PIB, no quinto ano de vigência desta Lei (2019) e, no mínimo, o equivalente a 10\% do PIB ao final do decênio (2024). Mas, com a Emenda Constitucional apelidada de PEC do fim do mundo, que impede o aumento dos gastos públicos por 20 anos, todas essas metas já estão inviabilizadas pelo menos até 2036. Acresce que a meta de $10 \%$ do PIB em educação foi viabilizada pela decisão dos governos do PT de destinar recursos do pré-sal para esse fim. Agora, porém, além do congelamento dos gastos públicos por 20 anos, os recursos do pré-sal também deixarão de estar disponíveis, pois a exploração dessas imensas reservas de petróleo está sendo entregue, na "bacia das almas”, às empresas internacionais.

Mas a inviabilização das metas do PNE é apenas um dos aspectos pelos quais as reformas regressivas do governo Temer procura neutralizar os limitados avanços dos governos Lula e Dilma, retomando o espírito autoritário que foi a marca do período da ditadura militar. Esse autoritarismo fica evidente na reforma do ensino médio, baixada por medida provisória sem sequer dar conhecimento prévio às Secretarias de Educação e aos Conselhos Estaduais de Educação que, pela Constituição e pela LDB, são os responsáveis pela oferta pública desse nível de ensino. Como responsáveis pelo Ensino Médio os estados e o Distrito Federal deveriam ser consultados sobre a proposta de reforma desse nível de ensino. No entanto, nem mesmo foram infor- 
mados, sendo surpreendidos com a entrada em vigor da referida reforma uma vez que, sendo baixada por medida provisória, passa a valer imediatamente após sua promulgação.

Mas como justificar o recurso à Medida Provisória na reforma do ensino médio? Na verdade, o estatuto jurídico da Medida Provisória é equivalente ao do Decreto-Lei, instrumento de que, normalmente, lançam mão os regimes ditatoriais nos quais o Executivo enfeixa em si as prerrogativas do Poder Legislativo. Nesse sentido esse dispositivo da Constituição de 1988 (Art. 62, modificado pela Emenda n. 32, de 11 de setembro de 2001) tem como antecedentes o DecretoLei das Constituições de 1937, da ditadura do Estado Novo e de 1967 com a Emenda n. 1, de 1969, da ditadura militar e, como inspiração mais direta, o "provvedimento provvisorio" italiano, disciplinado no art. 77 da Constituição de 1947, usualmente conhecido por "decretolegge". Mas há uma nítida diferença entre o "provvedimento provvisorio" italiano e a "medida provisória” brasileira, que fica clara na resposta a uma pergunta que teria sido feita pelo próprio Michel Temer quando era apenas vice-presidente: o que acontece se a medida provisória não for aprovada pelo Parlamento Italiano? Resposta curta e grossa: "O Gabinete cai”, pois o modelo político italiano é diferente do brasileiro que não responsabiliza politicamente o Presidente da República no caso de não aprovação da medida provisória. Por isso, embora a Constituição estabeleça que a edição de medida provisória deva ocorrer apenas "em caso de relevância e urgência”, os presidentes da República têm abusado do dispositivo da medida provisória adotando-o indiscriminadamente de acordo com seu exclusivo alvedrio, cioso de que não arcará com consequência alguma no caso de não aprovação pelo Poder Legislativo. Assim é que no caso atual de um governo ilegítimo, a medida provisória se converte num recurso para o exercício de um poder autoritário. É nessa circunstância que a Reforma do Ensino Médio foi baixada pela Medida Provisória n. 746, de 22 de setembro de 2016 .

Logo que foi promulgada a medida provisória foi alvo de uma avalanche de críticas provenientes do Fórum Nacional de Educação, dos Conselhos e Secretarias estaduais de educação, assim como de diversas entidades representativas dos profissionais da educação. No entanto, o governo, em lugar de levar em conta as críticas revendo a ori- 
entação impressa à reforma, ignorou-as e lançou uma agressiva campanha publicitária com muitas inserções diárias nos meios de comunicação chegando, inclusive, ao desplante de colocar no ar uma propaganda com um indivíduo que afirmava que sua vida mudou quando passou a cursar uma escola de tempo integral, o que lhe permitiu entrar na faculdade, obter uma bolsa para se formar engenheiro na Espanha e agora é um profissional reconhecido na Espanha. Ora, então essa é uma propaganda do governo do PT, pois essa pessoa cursou a escola de tempo integral bem antes dessa reforma do ensino médio e, além disso, teria se beneficiado do Programa "Ciência sem Fronteira", do governo Dilma, para obter a bolsa e estudar na Espanha. Mas a população, de modo geral, não faz essa ilação e acaba sendo induzida a acreditar que esse governo a está favorecendo. Na verdade, o que esse governo resultante do golpe está fazendo é destruir os limitados avanços dos governos do PT.

O caráter autoritário fica claro, também, na intervenção no Fórum Nacional de Educação mudando sua composição sem consulta às entidades que, conforme as normas legais, nele têm assento. E, à revelia do que dispõe a lei 13.005, de 25 de junho de 2014, que aprovou o Plano Nacional de Educação 2014-2024, retirou do Fórum Nacional de Educação a incumbência de coordenar o processo de preparação e realização das Conferências Nacionais de Educação transferindo-a, por decreto, à Secretaria Executiva do MEC.

Tal autoritarismo se faz presente, ainda, no movimento "escola sem partido", merecidamente chamado por seus críticos de "lei da mordaça”, pois explicita uma série de restrições ao exercício docente negando o princípio da autonomia didática consagrado nas normas de funcionamento do ensino. Passei, então, ao final da aula, a tratar do projeto "Escola sem partido" que surgiu no âmbito da sociedade civil, se constituiu como uma ONG (Organização não governamental) e passou a ser apresentado na forma de projetos de lei na Câmara dos Deputados, no Senado Federal e em várias Assembleias Estaduais e Câmaras Municipais do país.

Analisei o referido projeto mostrando que tem um duplo componente: o primeiro é de caráter global, uma vez que devido à atual crise estrutural do capitalismo a classe dominante, não podendo se impor racionalmente, precisa recorrer a mecanismos de coerção no pla- 
no da sociedade política combinados com iniciativas de persuasão no plano da sociedade civil que envolvem o uso maciço dos meios de comunicação e a investida no campo da educação escolar transformada em instrumento de doutrinação; o segundo componente tem a ver com a especificidade da formação social brasileira marcada pela resistência de sua classe dominante em incorporar os de baixo na vida política, tramando golpes sempre que pressente o risco da participação das massas nas decisões políticas. Daí o caráter espúrio de nossa democracia alternando a forma restrita, quando o jogo democrático é formalmente assegurado, com a forma excludente em que a denominação "democracia” aparece como eufemismo de ditadura. É essa classe dominante que agora, no contexto da crise estrutural do capitalismo, dá vazão ao seu ódio de classe mobilizando uma direita raivosa que se manifesta nos meios de comunicação convencionais, nas redes sociais e nas ruas.

Prosseguindo na análise do projeto "Escola sem partido" retomei as considerações feitas em "Onze tese sobre educação e política”, último capítulo de meu livro Escola e democracia (SAVIANI, 2018, p. 65-73) considerando que, sendo uma relação que se trava entre antagônicos, a política supõe a divisão da sociedade em partes inconciliáveis devendo, necessariamente, ser partidária. Inversamente, a educação, por ser uma relação entre não antagônicos, supõe a união e tende para a universalidade não podendo, portanto, ser partidária. A prática política se apoia na verdade do poder, enquanto a prática educativa se apoia no poder da verdade. $\mathrm{E}$ a verdade, a ciência, não é desinteressada. No entanto, a classe dominante não se interessa pela verdade, pois isso evidenciaria a dominação que exerce sobre as outras classes. Em contraposição, a classe dominada tem todo interesse que a verdade se manifeste porque isso põe em evidência a exploração a que é submetida, engajando-a na luta de libertação.

Fica claro, portanto, que os professores identificados com a transformação estrutural da sociedade, tendo a verdade de seu lado, não precisam doutrinar. A eles basta analisar a realidade empenhando-se em que os alunos a compreendam de forma objetiva. Portanto, contrariamente ao proclamado, são exatamente os adeptos da "Escola sem partido" que necessitam doutrinar incutindo nos alunos normas transcendentes, supostamente universais e ocultando as con- 
tradições e conflitos que constituem a realidade da sociedade de classes.

Assim, considerando que o entendimento da pedagogia histórico-crítica sobre as relações entre escola e política é aquele que está sucintamente expresso no capítulo quarto do livro Escola e democracia, denominado "Onze teses sobre educação e política", retomei o enunciado das onze teses, para concluir:

$\mathrm{Na}$ sociedade de classes, portanto, na nossa sociedade, a educação é sempre um ato político, dada a subordinação real da educação à política. Dessa forma, agir como se a educação fosse isenta de influência política é uma forma eficiente de colocá-la a serviço dos interesses dominantes. E é esse o sentido do programa "escola sem partido" que visa, explicitamente, subtrair a escola do que seus adeptos entendem como "ideologias de esquerda", da influência dos partidos de esquerda colocando-a sob a influência da ideologia e dos partidos da direita, portanto, a serviço dos interesses dominantes. Ao proclamar a neutralidade da educação em relação à política, o objetivo a atingir é o de estimular o idealismo dos professores fazendo-os acreditar na autonomia da educação em relação à política, o que os fará atingir o resultado inverso ao que estão buscando: em lugar de, como acreditam, estar preparando seus alunos para atuar de forma autônoma e crítica na sociedade, formarão para ajustá-los melhor à ordem existente e aceitar as condições de dominação às quais estão submetidos. Eis por que a proposta da escola sem partido se origina de partidos situados à direita do espectro político com destaque para o PSC (Partido Social Cristão), PSL (Partido Social Liberal) e PSDB (Partido da Social Democracia Brasileira) secundados pelo DEM (Democratas), PP (Partido Popular), PR (Partido da República), PRB (Partido Republicano Brasileiro) e os setores mais conservadores do MDB (Partido do Movimento Democrático Brasileiro). Como se vê, a "escola sem partido" é, de fato, uma escola de partido; é a escola dos partidos da direita, os partidos conservadores e reacionários que visam manter o estado de coisas atual com todas as injustiças e desigualdades que caracterizam a forma de sociedade dominante no mundo de hoje.

À vista, pois, do caráter reacionário do movimento denominado "Escola sem partido" é preciso evitar a aprovação do projeto de lei que pretende torná-lo obrigatório em todas as escolas do país. A luta 
contra o projeto de lei deve ser travada mostrando que se trata de uma aberração, pois fere o bom senso ao retirar dos professores o papel que lhes é inerente de formar as novas gerações para se inserir ativamente na sociedade, o que implica trabalhar com os alunos os conhecimentos disponíveis tendo como critério e finalidade a busca da verdade sem quaisquer tipos de restrição. Vai na contramão do lugar atribuído à escola na sociedade moderna que no final do século XVIII forjou o conceito de escola pública estatal, de caráter universal, obrigatória, gratuita e laica e buscou implantar, no século XIX, os sistemas nacionais de ensino como instrumentos de democratização com a função de converter os súditos em cidadãos. E nega os princípios e normas que compõem o aparato jurídico vigente no Brasil sendo manifestamente anticonstitucional.

A resistência ativa, que propus na conclusão do livro sobre a atual LDB (SAVIANI, 2016, p. 303-307) é, pois, indispensável como estratégia de luta por uma escola pública livre das ingerências privadas balizadas pelos interesses do mercado. Nessa fase difícil que estamos atravessando, marcada por retrocesso político com o acirramento da luta de classes lançando mão da estratégia dos golpes parlamentares visando a instalar governos ilegítimos para retomar sem rebuços a agenda neoliberal, derrotada nas urnas, resulta imprescindível combatermos as medidas restritivas dos direitos sociais, entre eles, o direito a uma educação de qualidade, pública e gratuita, acessível a toda a população. Essa foi e continua sendo, agora de forma ainda mais incisiva, a luta de todos os educadores do Brasil.

\section{REFERÊNCIAS}

KORYBKO, Andrew. Guerras híbridas: das revoluções coloridas aos golpes. São Paulo: Expressão Popular, 2018.

MARX, Karl. O Capital. Rio de Janeiro: Civilização Brasileira, 1968.

MARX, Karl. A Questão Judaica. Rio de Janeiro: Achiamé. s/d.

SAVIANI, Dermeval. A lei da educação (LDB): trajetória, limites e perspectivas, $13^{\underline{a}}$ ed., revista, atualizada e ampliada com um novo capítulo. Campinas: Autores Associados, 2016. 
. Escola e democracia, $43^{\underline{a}}$ ed. Campinas, Autores Associados. 2018.

ZANOTTI, Jorge Luis. Etapas históricas de la política educativa. Buenos Aires: Eudeba, 1972. 



\title{
GOLPES DE ESTADO E EDUCAÇÃO NO BRASIL: A PERPETUAÇÃO DA FARSA
}

\author{
Sosé Flaudinei Rombardi \\ charcos Q. Rima
}

\section{Introdução}

É sempre complicado construir uma análise conjuntural, notadamente por estarmos imersos na conjuntura. Em pleno processo golpista que desembocou no Golpe de 2016, buscamos fazer uma análise sobre o golpe de 2016 no Prefácio ao livro A crise da democracia brasileira (LOMBARDI e LIMA, 2017), onde analisamos os sucessivos golpes de Estado no Brasil como contrarrevoluções preventivas, pelas quais as elites econômicas e políticas historicamente retomaram o poder, fazendo retroceder políticas sociais e populares , restabelecendo a ordem conservadora e seus desdobramentos políticos antidemocráticos, antipopulares, anticomunistas, antinacionais e pró-imperialistas.

Transcorridos dois anos do golpe de 2016, impossível não retomar as características dos golpes de Estado do país, como acima expresso, buscando pontuar alguns aspectos de uma conjuntura marcada por rápido agravamento da economia nacional e, consequentemente, das políticas sociais. A taxa de desemprego no primeiro trimestre de 2018 superou os $11,8 \%$ do ano anterior, atingindo, segundo dados da Agência IBGE de Notícias ${ }^{1}$, atingindo $13,1 \%$ da população economicamente ativa. Antes, durante o governo petista, o país que se vangloriava por ter gerado 20 milhões de empregos na última década; agora soma, no escancarado período de ofensiva neoliberal, aproximadamente 13,7 milhões de desempregados.

"DOI - 10.29388/978-85-53111-28-2-()-f.47-62

${ }^{1}$ Dados disponíveis em: <https://agenciadenoticias.ibge.gov.br/agencia-noticias/2012-agenciade-noticias/noticias/20995-desemprego-volta-a-crescer-no-primeiro-trimestre-de-2018.html> 
O Programa "Uma Ponte Para o Futuro", ao contrário do propalado crescimento econômico, deixa transparente as verdadeiras intenções do golpe de 2016: promover uma profunda e aberta guinada conservadora através da adoção da perspectiva neoliberal, a desregulamentação do mundo do trabalho para aumentar a exploração dos trabalhadores, mesmo que à custa de recessão e estagnação, concentração ainda mais ampla da riqueza, malgrado o reconhecimento internacional da redistribuição ocorrida durante a chamado "era" neodesenvolvimentista, capitaneada pelo Partido dos Trabalhadores (PT), cujos dados evidenciam o aumento da renda média da população brasilei$\mathrm{ra}^{2}$. Com a ofensiva neoliberal, os avanços sociais que retiraram da linha da pobreza cerca de 40 milhões de brasileiros, rapidamente foram atingidos, incorporando-se aos tradicionais setores excluídos - negros, mulheres e crianças, pessoas com baixa escolaridade - homens brancos, adultos e escolarizados (POCHMANN, 2018).

Esse contexto, por si só preocupante, teve seus efeitos acentuados com a Proposta de Emenda Constitucional (PEC) no. 95, de 15 de dezembro de 2016, chamada de "PEC do fim do mundo" e que congelou por 20 anos os investimentos públicos, inviabilizando atendimentos médicos, programas de acesso à moradia, infraestrutura, saneamento básico etc. Não por acaso, doenças há muito erradicadas, como a tuberculose e a febre amarela, voltaram a assombrar a população brasileira.

Almejando recuperar a taxa de lucro abalada desde a crise capitalista de 2008, manifestada com a crise imobiliária norte-americana, o capital financeiro internacional avança sobre os fundos públicos, achatando salários e eliminando direitos trabalhistas, criando assim novas válvulas de escape para a crise, por meio da expansão de sua totalidade extensiva e de sua totalidade intensiva (MÉSZÁROS, 2011, p. 591).

Inserida nesse movimento do capital, a educação pública vem sendo duplamente atacada: por um lado, torna-se mercadoria no balcão de negócios e ações das grandes corporações de ensino privadas; por outro, como tendencialmente ocorre em períodos golpistas, adequam a educação das massas à reorganização das bases produtivas,

\footnotetext{
${ }^{2}$ Ver: <https://economia.ig.com.br/2015-11-13/renda-dos-mais-pobres-cresce-acima-da-mediada-populacao-brasileira.html.>.
} 
tornando a escola um aparelho privado da hegemonia empresarial corporativa. Como a educação não pode ser separada da totalidade histórico-social em que se produz, é no interior da atual crise capitalista que encontra-se a atual crise da educação (MÉSZÁROS, 2006, p. 274).

É espantosa a rapidez com que os recursos públicos destinados à educação e a outras políticas sociais têm sido expropriados, evidenciando a fragilidade do reformismo neodesenvolvimentista que, num curto período de ofensiva neoliberal, teve seus principais projetos desestruturados. Um só exemplo é ilustrativo: com a redução de recursos, as metas do Plano de Desenvolvimento da Educação (PDE), lançado em 2007, pelo então presidente Luiz Inácio Lula da Silva (SAVIANI, 2009), praticamente foram inviabilizadas, seja por meio de profundos ajustes fiscais que visam garantir o pagamento de juros da dívida pública, seja através da mercadorização do ensino estatal, cujos parcos recursos são disputados por empresas privadas que, com o governo golpista se viram diretamente representadas no MEC através do administrador de empresas Mendonça Filho.

A chave teórica para entender o que está ocorrendo com a educação foi recolocada por Emir Sader no Prefácio ao livro $A$ educação para além do capital, de István Mészáros: “[...] digam-me onde está o trabalho em um tipo de sociedade e eu te direi onde está a educação" (MÉSZÁROS, 2005, p. 17). Não por acaso, a Reforma Trabalhista do governo golpista de Michel Temer, somado a Lei 13.429/17, que autoriza a terceirização ilimitada e irrestrita, liberando a terceirização de "atividades fins" anteriormente protegidas desse artifício de intensificação da exploração da força de trabalho, são a base concreta para pensarmos as reformas educacionais anunciadas pelo $\mathrm{MEC}^{3}$. Na atual fase de reestruturação flexível da base produtiva, a escola pública é convocada pelo Estado golpista para adequar a classe trabalhadora aos ditames do mercado de trabalho. Isso ocorre sustentado por grupos empresariais, articulados no interior de movimentos como o "To-

\footnotetext{
${ }^{3}$ Sarcasticamente, professores da rede pública convocados de maneira autoritária para um tendencioso dia de discussão sobre a BNCC, denominado de "Dia D", atribuíram às atuais mudanças na educação o título de "Reforma Alexandre Frota", assim intitulada devido ao protagonismo do ator de filmes pornográficos Alexandre Frota, que, diferentemente das entidades que representam estudantes e professores, teve livre acesso à sala do Ministro da Educação, Mendonça Filho.
} 
dos Pela Educação" e o "Escola Sem Partido", que a pretexto de defenderem um pacto em defesa da educação e o combate à doutrinação político ideológica no âmbito escolar, combatem a reflexão crítica sobre as contradições sociais, sobretudo as contradições do mundo do trabalho e que também permeiam a vida de estudantes e professores.

Em O Brasil republicano: uma história de golpes de Estado (LOMBARDI; LIMA, 2017), evidenciamos que a estruturação do Estado brasileiro, desde seus primórdios, desdobrou-se em períodos de transição conservadora, marcados por golpes "pelo alto", mantendo na subalternidade as diferentes frações da classe trabalhadora. Vários foram os golpes ao longo de nossa história, desde a Proclamação da República, da qual o povo, sujeito histórico privilegiado no ideário republicano, foi mantido ausente, apenas assistindo, conforme Aristides Lobo, "bestializado" ao que entendia ser talvez uma "parada militar" (cf. CARVALHO, 1987, p. 9).

O presente texto retoma o pressuposto marxiano de que a história somente se repete como farsa, desenvolvido no livro de Marx $O$ 18 Brumário de Luís Bonaparte (MARX, 1997, p. 21). Se no texto anterior destacamos a recorrência do caráter golpista nos processos de transição, aqui defenderemos a tese de que o atual golpe na educação nada mais faz do que reeditar o (neo)tecnicismo que, alimentado pela guinada conservadora, assume ares autoritários de uma farsa que necessita se perpetuar.

Na primeira parte do texto, Golpe de Estado e educação no Brasil contemporâneo, apresentamos um breve preâmbulo sobre o atual golpe na educação, enfatizando a íntima relação entre Estado, trabalho e educação, destacando elementos que justificam nossa com-

\footnotetext{
${ }^{4}$ Ambos organizados já nos primeiros anos do governo Lula. O primeiro tem origem na articulação de setores empresariais, liderados, dentre outros, pela Fundação Lemann. Criada em 2006, essa articulação civil-empresarial deu origem ao "Compromisso Todos Pela Educação", um verdadeiro "Cavalo de Troia" no interior do Plano de Desenvolvimento (PDE), institucionalizado por meio da Lei 6.094, de 24 de abril de 2007. O movimento Escola Sem Partido tem origem o ano de 2004, com a criação da ONG Escola Sem Partido, pelo advogado Miguel Nagib. Ambos os movimentos vêm na esteira do processo de ampliação do campo de ação estratégica do Estado capitalista ocorrido nas décadas anteriores, que a pretexto de abrir espaço à participação democrática da sociedade civil no contexto de transição tutelada, após duas décadas de ditadura civil-militar, almejava na verdade controlar a perspectiva histórica transformadora das iniciativas populares, tornando cada vez mais orgânicos seus métodos imposição do consenso.
} 
preensão de que o complexo institucional do Estado foi uma vez mais acionado pelo Golpe de 2016, cujo caráter orgânico torna "gelatinosa" qualquer definição das instituições que seriam o lócus privilegiado do Golpe.

Na segunda parte, intitulada Trabalho e educação no contexto da crise capitalista e ofensiva neoliberal, ancorados na tese de que a crise estrutural do capital é um elemento fundamental para a compreensão da crise da educação, evidenciamos os fundamentos neotecnicistas que orientam as atuais mudanças no âmbito da educação, destacando que não basta ao capital a reestruturação da base produtiva, mas (cf. GENTILE, 1998) é necessário impor o consenso ou falsificálo.

Ao final enfatizamos que nenhuma saída realista para a histórica crise da educação é possível fora da superação do modo capitalista de produção. É necessário pensar a educação inserida na problemática do processo de transição em curso sintetizado na assertiva de Rosa Luxemburgo: "socialismo ou barbárie", revigorada por Mészáros em O século XXI: socialismo ou barbárie (MÉSZÁROS, 2012).

\section{Golpe de Estado e educação no Brasil contemporâneo}

Mal deu tempo para os educadores comemorarem o Plano Nacional de Educação (2014-2024), Lei 13.005 que, entre outras metas, previa em sua meta de 20 anos a ampliação dos investimentos em educação ao patamar para 10\% do PIB até 2024, novo golpe de Estado tornou letra morta as conquistas sociais, inclusive o PNE. Não é demais registrar que os recursos para a ampliação dos investimentos em educação seriam garantidos por meio das reservas brasileiras de pré-sal, recentemente descobertas, mas isso não agradou as grandes corporações de exploração do petróleo. Não é estranho, portanto, o orquestrado ataque à Petrobras e a aprovação, em novembro de 2016 da Lei 13.365, acabando com o controle nacional sobre a exploração do pré-sal. Era isso o que vinha sendo preparado pela "Operação Lava Jato”, sob a batuta do Juiz Federal Sérgio Moro, e que foi denunciado por Marilena Chaú logo nos primeiros momentos do golpe como sendo um agente da CIA e que atingia seu principal objetivo. Alvo de desmoralização de que era um “antro de corrupção”, a Petro- 
bras, até então a maior e a mais lucrativa empresa nacional, responsável pelo desenvolvimento da tecnologia do pré-sal, sob o comando de Pedro Parente, passou a ser dilacerada, inviabilizando o plano neodesenvolvimentista de alavancar o desenvolvimento da educação nacional e de políticas sociais.

Fora do espectro conservador, é praticamente unânime a análise que o golpe de 2016 é contra a classe trabalhadora. Mais que isso, é uma contrarrevolução que mantém suas características históricas: é antinacional, antipopular, antidemocrático e pró-imperialista. Através do golpe garante-se a acumulação do capital monopólico internacional, com o uso crescente da repressão e da violência institucionalizada. Com o retrógrado lema do governo golpista - "ordem e progresso ${ }^{5 "}$ o Estado brasileiro articula todas as suas forças midiáticas, parlamentares, empresarial-corporativas, religiosas, avançando contra as irrisórias conquistas sociais, entre as quais a educação pública e gratuita para os trabalhadores.

Em sua ânsia por recuperar a taxa de lucro abalada pela crise estrutural, não bastou ao capital expropriar os recursos da educação, pois também é preciso controlar ideologicamente o conteúdo, pois nenhum gérmen de "educação para além do capital” pode prosperar. É no interior dessa totalidade operante que as hodiernas (contra)reformas neoliberais da educação devem ser entendidas: são mudanças educacionais para preparar para as alterações que ocorrem no mundo do trabalho, legalizados pela Lei 13.429, publicada em 31 de março de 2017, que liberou a terceirização "irrestrita”, possibilitando a contratação de terceirizados para "atividades fins" e, com isso facilitando a introdução da flexibilização de direitos; esta deu-se com a Lei 13.467, de 13 de julho de 2017, que flexibilizou os direitos trabalhistas, intentando não somente intensificar a exploração dos trabalhadores, mas inviabilizar as formas de organização da classe trabalhadora, sobretudo os sindicatos.

\footnotetext{
${ }^{5}$ Como destacamos no texto anterior, o vínculo com o imperialismo estadunidense é tão evidente que um dos integrantes da Lava Jato, o procurador Deltran Dalagnon, chegou a afirmar que os norte-americanos são "cidadãos de ordem superior”, devido ao tipo de colonização que prevaleceu na América do Norte. Para Dallagnon, a corrupção no Brasil se deve ao fato de que com a colonização vieram para o Brasil os degredados portugueses, enquanto para os EUA se deslocaram cristãos de bem em busca de seus sonhos (cf. LOMBARDI; LIMA, 2017, nota de rodapé $n^{\circ} 13$ ).
} 
Como enunciamos anteriormente, em um contexto marcado pela ofensiva do capital sobre o trabalho, a educação dos trabalhadores não poderia passar incólume:

[...] além da reprodução, numa escala ampliada, das múltiplas habilidades sem as quais a atividade produtividade não poderia ser levada a cabo, o complexo sistema educacional da sociedade é também responsável pela produção e reprodução da estrutura de valores no interior da qual os indivíduos definem seus próprios objetivos e fins específicos. As relações sociais de produção reificadas sob o capitalismo não se perpetuam automaticamente. Elas só o fazem porque os indivíduos particulares interiorizam as pressões externas: eles adotam as perspectivas gerais da sociedade de mercadorias como limites inquestionáveis de suas próprias aspirações. É com isso que os indivíduos "contribuem para manter uma concepção de mundo" e para a manutenção e uma forma específica de intercâmbio social, que corresponde àquela concepção de mundo (MÉSZÁROS, 2006, p. 263-264).

Foi essa a direção tomada pelo Estado para adequar o sistema educacional às formação para as múltiplas habilidades necessárias à produção, bem como para interiorizar a ideologia adequada à concepção de um mundo da sociedade burguesa. Para tanto, foram retomados os fundamentos da pedagogia tecnicista, substrato teórico-metodológico da atual ofensiva neoliberal sobre a educação pública brasileira:

A partir do pressuposto da neutralidade científica e inspirada nos princípios de racionalidade, eficiência e produtividade, essa pedagogia advoga a reordenação do processo educativo de maneira a torná-lo objetivo e operacional. De modo semelhante ao que ocorreu no trabalho fabril, pretende-se a objetivação do trabalho pedagógico. Com efeito, se no artesanato o trabalho era subjetivo, isto é, os instrumentos de trabalho eram dispostos em função do trabalhador e este dispunha deles segundo seus desígnios, na produção fabril essa relação é invertida. Aqui, é o trabalhador que deve adaptar-se ao processo de trabalho, já que este foi objetivado e organizado na forma parcelada. [...] $\mathrm{O}$ fenômeno mencionado ajuda-nos a entender a tendência que se esboçou com o advento daquilo que estou chamando de "pedagogia tecnicista”. Buscou-se planejar a educação de modo a dotá-la de uma organização racional capaz de minimizar as in- 
terferências subjetivas que pudessem por em risco sua eficiência. Para tanto, era mister operacionalizar os objetivos e, pelo menos em certos aspectos, mecanizar o processo. Daí a proliferação de propostas pedagógicas tais como o enfoque sistêmico, o microensino, o telensino, a instrução programada, as máquinas de ensinar etc. (SAVIANI, 2009, p. 11).

Esses fundamentos pedagógicos, ressurgiram nos anos de 1990, com o que Saviani denominou de neoprodutivismo, no interior do qual se destacam as variantes: neoescolanovismo, neoconstrutivismo e neotecnicismo (SAVIANI, 2010, p. 425), reunidas no interior do que Duarte classifica de "pedagogias do aprender a aprender", ancoradas no fetichismo da sociedade do conhecimento, ansiosa por formar indivíduos capazes de se adaptar aos ditames da sociedade capitalista (DUARTE, 2003, p. 5). Na perspectiva do "aprender a aprender”, cabe à educação proporcionar aos indivíduos a aquisição de um repertório de "habilidades e competências" para a sobrevivência em uma sociedade caracterizada pelas incertezas do mercado de trabalho. Para tanto, é preciso redefinir o papel do Estado e reorganizar as escolas, adequando-as aos ditames da reestruturação produtiva capitalista. Assim, a ênfase tecnicista nas habilidades e competências, para além da formação elementar para o processo produtivo, também cumpre um papel ideológico extremamente importante: ocultar a luta de classes que permeia o espaço escolar ${ }^{6}$, impondo a ideia de consenso sobre as relações sociais de produção vigentes. Como observa Saviani:

O empenho em introduzir a "pedagogia das competências" nas escolas e nas empresas moveu-se pelo intento de ajustar o perfil dos indivíduos, como trabalhadores e como cidadãos, ao tipo de sociedade decorrente da reorganização do processo produtivo. Por isso nas empresas se busca substituir o conceito de qualificação pelo de competência e, nas escolas, procura-se passar do ensino centrado nas disciplinas de conhecimento para o ensino por competências referidas a situações determinadas. Em ambos os casos o objetivo é maximizar a eficiência, isto é, tor-

\footnotetext{
${ }^{6}$ Como observam Duarte e Saviani, a grande contradição presente no interior da escola pública, tornando inevitável que luta de classes permeie o trabalho escolar, é que a socialização do conhecimento em suas formas mais desenvolvidas, tarefa precípua da escola, choca-se com interesse contrário dos capitalistas, uma vez que socializar conhecimentos é socializar parte dos meios de produção (DUARTE; SAVIANI, 2012, p. 2).
} 
nar os indivíduos mais produtivos tanto em sua inserção no processo de trabalho como em sua participação na vida da sociedade (SAVIANI, 2010, p. 438).

Não tem sido outro o intuito das reformas educacionais em curso que, implementadas por um governo sem legitimidade, não somente subverte o papel da escola, desconstruindo a capacidade crítica para a tomada de decisão, mas conduz ao imobilismo e a negação da necessária participação dos indivíduos em seus instrumentos de organização política. Não tem sido por acaso que os sindicatos de professores e as organizações do movimento estudantil tem sido descredenciadas como interlocutores no processo de atuação em curso.

Ao contrário da mobilização e organização classista, a atual ofensiva golpista é marcada por profundos cortes no orçamento da educação; pela perseguição a todos aqueles que se contrapõem às reformas; pela implementação da racionalidade empresarial na gestão escolar, influenciando diretamente os currículos escolares por meio da pedagogia empresarial-corporativa. Com isso, o capital realiza um duplo movimento: por um lado, buscando recompor a taxa de lucro, por meio da expropriação dos recursos públicos destinados à educação; por outro, exercendo o controle ideológico no interior das escolas, desqualificando o conhecimento técnico, científico, artístico, filosófico e humanístico historicamente produzido pela humanidade e que deveria se constituir no conteúdo fundamental da formação da classe trabalhadora. A desqualificação da escola, criticada por Frigotto não se restringe ao ataque aos professores progressistas, mas ao próprio saber humano elaborado, a pretexto de se defender uma escola neutra, sem a influência partidária, ocultando-se a ditadura do partido único do capital em seu interior.

Não é nossa intenção apresentar uma profunda análise das transformações em curso no âmbito da educação, mas apresentar suas linhas gerais, evidenciando o seu estreito vínculo com as alterações no âmbito produtivo impostas pelo Golpe em curso. Para tanto, apontaremos a seguir a presença no interior das propostas de implementação da Base Nacional Comum Curricular (BNCC) e a proposta de Reforma do Ensino Médio anunciadas pelo MEC dos fundamentos teóricometodológicos anteriormente apontados como substrato das atuais reformas educacionais. 


\section{Trabalho e educação no atual contexto da crise capitalista e ofensiva neoliberal: os fundamentos neotecnicistas do "novo" golpe na educação}

Em 2015, o Estado de São Paulo nos apresentou um preâmbulo do golpe na educação, depois imposto nacionalmente pela coalizão que tomou de assalto o poder executivo, tendo no PSDB do então governador Geraldo Alckmin, candidato à presidência da República nas eleições de 2018, sua "tropa de elite". Como afirmamos em artigo publicado na Revista HISTEDBR On-Line:

A reorganização das escolas oculta na verdade um duplo ataque de cunho neoliberal. Primeiramente, busca-se desarticular a resistência dos profissionais da educação, juntamente com sua capacidade de controle sobre o trabalho escolar, graças à introdução de estratégias inspiradas no modelo de gestão empresarial, preparando o processo de privatização da escola pública. $\mathrm{O}$ segundo é que, minada a capacidade de resistência ao projeto de reestruturação, avança-se na adequação do currículo escolar aos ditames neotecnicistas, por meio da Reforma do Ensino Médio, reconhecida pela SEE como o "foco das mudanças" (GONZALES: LIMA; LOMBARDI, 2017, p. 930).

Em São Paulo a reforma educacional atualmente imposta pelo MEC, já estava delineada, articulada à nova $\mathrm{BNCC}$, lançada por meio da Portaria no 331, de 5 de abril de 2018, que instituiu o ProBNCC. A BNCC foi aprovada pelo Conselho Nacional de Educação, no dia 15 de dezembro de 2017, homologada no dia 20, pelo então Ministro da Educação, Mendonça Filho. Com ela o neotecnicismo e a ênfase nas competências e habilidades se constituíram em elemento central da Base, como enfatiza texto do próprio MEC:

Na BNCC, competência é definida como a mobilização de conhecimentos (conceitos e procedimentos), habilidades (práticas, cognitivas e socioemocionais), atitudes e valores para resolver demandas complexas da vida cotidiana, do pleno exercício da cidadania e do mundo do trabalho (MEC). 
Nada de novo, pois já em 2017, a LDB 9394 (de 1996) foi alterada pela Lei 13.415, de 16 de fevereiro de 2017, definindo-se em seu Art. 4 que o art. 36 da Lei ${ }^{\circ}$ 9.394/96 passaria a vigorar com as seguintes alterações:

O currículo do ensino médio será composto pela Base Nacional Comum Curricular e por itinerários formativos, que deverão ser organizados por meio da oferta de diferentes arranjos curriculares, conforme a relevância para o contexto local e a possibilidade dos sistemas de ensino, a saber: I - linguagens e suas tecnologias; II - matemática e suas tecnologias; III - ciências da natureza e suas tecnologias; IV - ciências humanas e sociais aplicadas; $\mathrm{V}$ - formação técnica e profissional ${ }^{7}$.

Implementando a profissionalização precoce, nos moldes da Lei 5.692/71 da ditadura civil-militar, a nova Reforma do Ensino Médio busca impor a farsa tecnicista, representando um retrocesso no debate alimentado por expectativas criadas pelo processo de redemocratização, marcado pela luta em defesa da escola pública, resultando no Projeto Otávio Elísio de LDB, que dentre outras coisas, colocava como objetivo da educação escolar de $2^{\circ}$ grau: "[...] proporcionar aos adolescentes a formação politécnica necessária à compreensão teórica e prática dos fundamentos científicos e técnicos das múltiplas técnicas utilizadas no processo produtivo" (cf. FRIGOTTO; CIAVATTA; RAMOS, 2012, p. 25).

$\mathrm{Na}$ contramão das políticas educacionais tecnicistas, setores progressistas da comunidade educacional orientados pela relação trabalho e educação defendiam o vínculo entre a educação e a prática social, advogando o princípio educativo do trabalho:

Se o saber tem uma autonomia relativa em face do processo de trabalho o qual se origina, o papel do ensino médio deveria ser o de recuperar a relação entre conhecimento e prática do trabalho. Isto significa explicar como a ciência se converte em potência material no processo de produção. Assim, seu horizonte deveria ser o de proporcionar aos alunos o domínio dos fundamentos das técnicas diversificadas utilizadas na produção, e não o mero adestramento em técnicas produtivas. Não se deveria, 7 Disponível em: 〈http://www2.camara.leg.br/legin/fed/lei/2017/lei-13415-16-fevereiro-2017-
784336-publicacaooriginal-152003-pl.html.> 
então, propor que o ensino médio formasse técnicos especializados, mas sim politécnicos (ibidem, p. 35).

O texto da LDB 9394/94 não contemplou tais exigências. Apesar da defesa em seu art. $1^{\circ}, \$ 2^{\circ}$ de que a educação escolar "deverá vincular-se ao mundo do trabalho e a prática social”, preparando os estudantes para o exercício de profissões técnicas, a LDB não incorporou os fundamentos teórico-metodológicos da politecnia e do trabalho como princípio educativo, defendidos pelos setores ligados aos interesses dos trabalhadores, sindicais e populares. Ao contrário, predominou na LDBEN os fundamentos tecnicistas herdados da ditadura militar, apenas requentados pelas pedagogias do "aprender a aprender".

Orientação que foi contrariada pelo Decreto $\mathrm{n}^{\mathbf{0}}$ 2.208/97, de Fernando Henrique Cardoso, que, na contramão do que previa a LDB, determinou a separação entre o ensino médio e a educação profissional, não rompendo com o tradicional dualismo estrutural da educação brasileira. Com essa perspectiva, o CNE aprofundaria o conteúdo ideológico e pedagógico da reforma FHC, instituindo as Diretrizes Curriculares Nacionais para o Ensino Médio, através do Parecer CEB/CNE n.. 15/98. Por sua vez, as diretrizes da Educação Profissional de Nível Técnico foram definidas pelo Parecer $\mathrm{CEB} / \mathrm{CNE} \mathrm{n}^{\text {o }}$ 16/99 (ibidem, p. 29).

Note-se que no contexto do governo FHC, o PSDB, partido do então presidente, representado no âmbito da educação pelo Ministro Paulo Renato Souza, rechaçava a profissionalização no nível médio, como se evidencia nas Orientações Complementares aos Parâmetros Curriculares Nacionais, criticando o caráter transitório do ensino médio, como formação pré-universitária, por um lado, e, por outro, os limites da formação profissional, que enfatizava uma a especialização de caráter técnico em detrimento de uma formação mais geral. (MEC; SEMTEC, 2002, p. 8).

Apesar do esforço em se apresentar como síntese das lutas em defesa da escola pública travadas no contexto da redemocratização, ocultando o verdadeiro intuito de perpetuar a escola como um aparelho privado de hegemonia a serviço do capital monopólico internacional, ao qual haviam se articulado setores das forças armadas e das elites civil-empresariais nacionais em uma aliança que extrapolava o con- 
texto da ditadura, o caráter conservador das reformas educacionais do governo neoliberal de FHC era evidente.

As reformas traziam em seu bojo os elementos político-pedagógicos centrais que nas últimas décadas haviam sido delineados Consenso de Washington, de 1989 (GENTILE, 1998 p. 13), e a Conferência Mundial de Educação para Todos, realizada em Jomtien, na Tailândia, em 1991 (SHIROMA; MORAES; EVANGELISTA, 2007, p. 48), em consonância com as articulações do encontro anterior, que tendo um caráter político-econômico, determinava, em última instância, as propostas pedagógicas dos arautos das reformas educacionais.

Em sintonia com o fetichismo da "sociedade do conhecimento", tendo por base concreta a reestruturação capitalista, marcada pela desconstrução dos direitos sociais e o desemprego estrutural, caracterizados nos documentos oficiais como o "incerto, inusitado e urgente", o currículo escolar passou a ser estruturado a partir dos fundamentos do "aprender a aprender" e da "pedagogia das competências" (MEC; SEMTEC, 2002, p. 15; SEE de São Paulo, 2012, p. 12).

Em julho de 2004 Luiz Inácio Lula da Silva lançou o Decreto $\mathrm{n}^{\mathrm{o}} 5154$, restabelecendo a possibilidade para que o ensino técnico fosse ministrado nas escolas regulares em nível médio. Apesar dos dispositivos legais, isso não ocorreu, mantendo-se a base nacional comum curricular, ou Parâmetros Curriculares Nacionais, lançados em 1999 após a promulgação da LDB 9394/96, cuja definição era uma exigência prevista em seu art. 9o , inciso IV, o que resultou no Parecer $\mathrm{CNE} / \mathrm{CEB}$ n$^{-} 15$ e Resolução $\mathrm{CNE} / \mathrm{CEB}$ nº3/98. Desde então, passaram a ser definidas áreas de conhecimento no interior das quais os conteúdos disciplinares deveriam ser desenvolvidos: Linguagens, Matemática, Ciências da Natureza, Ciências Humanas (Resolução no 2, de 30 de janeiro de 2012, p. 2-3). No interior dessas áreas devem ser inter-relacionados os conteúdos das diferentes disciplinas escolares, mediados pelas "competências e habilidades" (MEC; SEMTEC, 2002, p. 17).

O ensino médio manteve essa orientação curricular até a apresentação da Lei 13.415/17, não enfrentando de maneira contundente a problemática da preparação para o trabalho prevista na LDB 9.394/96, em seu art. 35, incisos de 1 a 4. Estaria o MEC sob a égide do governo Temer agora disposto a resolver o histórico problema da 
dualidade da educação brasileira, atendendo à proposta de ensino médio integrado ao ensino técnico, implementando as mudanças estruturais que os governos Lula e Dilma, "embaraçados" (FRIGOTTO; CIAVATTA; RAMOS, 2012, p. 14) diante do poder das forças conservadoras que sobre eles insidiam não foram capazes de realizar? Quais seriam os verdadeiros interesses por trás do Golpe na educação?

No momento em que a sociedade brasileira assiste atônita à transferência do controle da Petrobras ao capital monopólico internacional, que, com a ajuda do Judiciário brasileiro, com destaque à figura do juiz de primeira instância Sérgio Moro, passou a controlar os recursos do pré-sal que haviam sido destinados à saúde e a educação pelo governo Dilma Rousseff, como garantia para aplicação de $10 \%$ do PIB na educação, prevista no PNE de 2014, o Banco Mundial disponibilizou US\$ 250 milhões para a Reforma do Ensino Médio, em forma de empréstimo aprovado pelo Senado Federal. Fica evidente não somente $o$ interesse de se manter a transferência do controle dos recursos energéticos às empresas estrangeiras, retomando-se o processo de endividamento das décadas de 1980 e 1990. Por sua vez, as grandes corporações de ensino provadas já estão a postos para colocar as mãos nos recursos públicos destinados à reforma. $\mathrm{O}$ que nos permite afirmar que, uma vez mais, foi dado um Golpe na educação, perpetuando-se a farsa da dependência por meio do congelamento da descolonização dos povos da América latina, denunciada por um dos símbolos da defesa da educação pública no Brasil, Florestan Fernandes (FERNANDES, 2015).

\section{Considerações finais}

Procuramos ao longo do texto evidenciar o caráter histórico da crise da educação brasileira, sua obsolescência programada e deliberada desqualificação do trabalho escolar, sintetizados no que Frigotto denomina de "produtividade da escola improdutiva". Acompanhando de perto as transformações na base produtiva, devidamente acionadas pelo capital, o Estado faz uso de instrumentos legais e ilegais para reconverter, de tempos em tempos, a estrutura de internalização dos pressupostos da divisão capitalista do trabalho, desestruturando as conquistas das classes subalternas no âmbito da educação. 
Em países periféricos como o Brasil, a crueldade do processo de reconversão é ainda maior, já que não se trata apenas de impedir o acesso da classe trabalhadora ao conhecimento elaborado produzido historicamente pelo conjunto da humanidade, mas de estrangular todo o complexo de desenvolvimento das forças produtivas, recolocando o país no lugar que lhe cabe na divisão internacional o trabalho.

\section{REFERÊNCIAS}

CARVALHO, José Murilo de. Os Bestializados: o Rio de Janeiro e a República que não foi. São Paulo: Companhia das Letras, 1987.

DUARTE, Newton. Sociedade do conhecimento ou sociedade das ilusões? Campinas: Autores Associados, 2003.

FERNANDES, Florestan. Poder e contrapoder na América Latina. $2^{\underline{a}}$ edição. São Paulo: Expressão Popular, 2015.

GENTILE, Pablo. A falsificação do consenso: simulacro e imposição na reforma educacional do neoliberalismo. Petrópolis-RJ: Vozes, 1998.

GONZÁLES, Jefferson; LIMA, Marcos. R.; LOMBARDI, J. C. A gestão empresarial da educação de São Paulo: o papel da tríade ideológica eficiência, produtividade e neutralidade. Revista HISTEDBR On-Line, v. 17, no 3 [73], p. 925-939, jul./set., 2017. Disponível em: <https:/periodicos.sbu.unicamp.br/ojs/index.php/histedbr/article/view 

LIMA, Marcos R. Educação, trabalho e hegemonia na Região Metropolitana de Campinas: uma análise da ação estratégica do "terceiro setor” e suas implicações político-pedagógicas. Dissertação. Universidade Estadual de Campinas, Faculdade de Educação, 2012. Disponível em: <http://repositorio.unicamp.br/ispui/handle/REPOSIP/250965.>

LOMBARDI, José Claudinei e LIMA, Marcos R.. Prefácio - O Brasil republicano: uma história de golpes de Estado. In: LUCENA, Carlos; Previtali, Fabiane Santana; Lucena, Lurdes. A crise da democracia brasileira - Volume I -. Uberlândia: Navegando Publicações, 2017. p. 1-30 Disponível em: <https://www.editoranavegando.com/copia-politicas-educacionais-1 $>$ 
LUCENA, C., PREVITALI, F. S., LUCENA, L. (orgs.). A crise da democracia brasileira. (Volume I). Uberlândia: Navegando Publicações, 2017.

MARX, Karl. O 18 Brumário e Cartas a Kulgelmann. Rio de Janeiro: Paz e Terra, 1997.

MÉSZÁROS, István. A teoria da alienação em Marx. São Paulo: Boitempo, 2006

POCHMANN, Marcio. Neoliberalismo do governo Temer trouxe a nova segregação social. Rede Brasil Atual, 07 de maio de 2018. Disponível em: $\lfloor$ https://www.redebrasilatual.com.br/blogs/blog-narede/2018/05/neoliberalismo-e-a-nova-segregacao-social.>

SAVIANI, Dermeval. PDE - Plano de Desenvolvimento da Educação: análise crítica da política do MEC. Campinas-SP: Autores Associados, 2009.

SAVIANI, Dermeval e DUARTE, Newton. Pedagogia histórico-crítica e luta de classes na educação escolar. Campinas: Autores Associados, 2012. 


\section{IV}

\section{A REVOLUÇÃO BURGUESA NO BRASIL E O GOLPE DE $2016^{*}$}

Debora Chazza

Gostaria de inserir o Golpe de 2016 em uma leitura diacrônica da Revolução Burguesa no Brasil a partir de certos processos e certos tipos humanos que nos ajudam a localizar historicamente o aparecimento das dinâmicas capitalistas e burguesas como uma realidade nacional. Busco interlocutores que ajudem a identificar a passagem da propensão pré-capitalista para a acumulação capitalista perseguindo os impactos desse processo econômico nas esferas política e psicossocial

Não se trata de detectar a essência do capitalismo em geral, mas o que caracteriza o capitalismo tardio que se configura no Brasil e em vários países periféricos. Como também, o papel que as burguesias nacionais tiveram na condução de uma revolução burguesa e na construção da ordem democrática.

Nesse sentido, indago os elementos constitutivos da organização da economia, da sociedade e do Estado que se tornaram historicamente viáveis no Brasil para buscar capturar, na complexidade dos processos, algumas regularidades e particularidades.

Existiu uma revolução burguesa no Brasil?

Distancio-me de pensar a histórica brasileira segundo esquemas da história dos povos da Europa central, e tento compreender como se processou a absorção do Brasil a um padrão estrutural e dinâmico de organização da economia, da sociedade, da cultura e do Estado segundo o regime capitalista inicialmente competitivo e depois monopolista, sob o poder burguês.

Como entender o ingresso do Brasil no capitalismo global desde uma perspectiva que assente, na longa duração, a Colônia, o Império e, principalmente, a República? (PRADO Jr, 1973)

*DOI - 10.29388/978-85-53111-28-2-()-f.63-78 
Como compreender a inserção do Brasil nos ciclos econômicos dos países ocidentais centrais participando tardiamente e em condições de subordinação no processo de acumulação primitiva, capitalismo competitivo e monopolista? (RIBEIRO, 1981)

Como explicar sua relação com os países e as dinâmicas econômicas das revoluções burguesas modernas sem, contudo, realizar o projeto de expansão dos direitos civis, políticos e sociais, sem a universalização do trabalho assalariado, sem contar com a maior participação da classe trabalhadora e sem respeitar o acesso a direitos humanos considerados básicos pelas democracias representativas?

Seria a Revolução burguesa brasileira uma revolução encapsulada e inacabada? Em que aspectos?

Estas perguntas parecem distante da discussão sobre o Golpe de 2016 mas elas importam para configurar os limites e as possibilidades de incorporação do povo na construção da ordem democrática no Brasil, quesito fundamental para a existência de uma democracia, ou seja, as possibilidades de participação concreta, não apenas jurídica, das classes sociais nos processos de produção, circulação e consumo dos bens materiais e imateriais amealhados pelas dinâmicas capitalistas burguesas que atravessam e constituem a sociedade brasileira.

Trata-se de identificar nas transformações histórico sociais os agentes humanos que estão por trás desses momentos considerados paradigmáticos de mudança, transformação ou de desagregação da ordem estabelecida e de surgimento de uma nova ordem.

Busco localizar os papéis sociais relegados ao povo brasileiro, ou seja, a grande massa de homens, mulheres, crianças e jovens que compõem a sociedade brasileira marcada pela diversidade e desigualdade sociocultural que envolvem índios, brancos, negros, mestiços e migrantes de todos os continentes.

Me deterei com mais vagar no período Republicano em virtude dos acontecimentos contemporâneos que envolvem o Golpe de 2016 e vou adotar como chave analítica prioritária o texto de Florestan Fernandes (1975), Revolução Burguesa no Brasil, para pinçar alguns momentos de aparentes rupturas e tentar perscrutar os papéis reservados aos principais grupos constitutivos da sociedade capitalista burguesa em momentos de interregnos ou potencialidades de viragens. 
Assim, dialogo com autores que questionam: 1- a natureza da transformação capitalista que nos coube na partilha do mundo; 2- os marcos da evolução possível desse capitalismo e os papéis assumidos pelos atores centrais da revolução de tipo burguesa, ou seja, a burguesia e o proletariado. (PRADO JUNIOR, 1973; FERNANDES, 1975; GORENDER, 1987).

Adoto o conceito de revolução burguesa como:

Um conjunto de transformações econômicas, tecnológicas, sociais, psicossociais e políticas que se realizam quando o desenvolvimento capitalista atinge o clímax de sua evolução industrial (FERNANDES, 1975, p.203)

Ou se preferir, outro:

Processo histórico concentrado em alguns anos ou decênios, mediante o qual a burguesia se apossa do poder do Estado, torna-se classe dominante e transforma o regime político-jurídico em favor da expansão desembaraçada das relações de produção capitalistas. (GORENDER, 1987, p. 254)

Ao contrário de outras burguesias que forjaram instituições próprias de poder especificamente social e só usaram o Estado para arranjos específicos, Fernandes (1975) sugere que a nossa burguesia converge para o Estado e faz acordos no plano político ao mesmo tempo em que converte sua dominação socioeconômica.

Assim, a oligarquia não perdeu a base de poder que lograra antes, como e enquanto aristocracia agraria e, além disso, encontrou condições para enfrentar a transição modernizando-se e desdobrando oportunidades novas. Por sua vez, a burguesia manteve e tirou proveito de arcaicas estruturas econômicas, sociais e políticas do País.

Florestan diz:

A burguesia não assume o papel de paladino da civilização ou instrumento da modernidade [...] ela se compromete com tudo que lhe fosse vantajoso [...] tira proveito dos tempos desiguais e da heterogeneidade da sociedade brasileira, mobilizando as vantagens que decorriam tanto do atraso quanto do adiantamento das populações. Por isso, não é apenas a hegemonia oligarquia que dilui o impacto inovador da dominação burguesa. A própria burguesia como um todo se ajustara à situação segundo uma linha de múltiplos interesses e adaptações ambíguas 
preferindo a mudança gradual e a composição a uma modernização impetuosa, intransigente e avassaladora [...] sua ansiedade política ia mais na direção de amortecer a mudança social, que de aprofundá-la. (FERNANDES, 1975, p. 204-205).

Além desse aspecto sócio dinâmico, o autor lembra que a burguesia comercial, industrial e financeira vinha de um estreito mundo provinciano, quer vivesse no campo ou na cidade, e sofrera a socialização e atração da oligarquia. O seu ambiente social era marcado por um entranhado conservadorismo intelectual e político que levava a uma acomodação e não uma modificação da história. O mandonismo oligárquico se manteve nas relações sociais burguesas.

A mesma burguesia que sucedeu a aristocracia na época da Independência foi conduzida a assumir os requisitos ideais e legais da ordem social competitiva. Ela se define em face dos papéis econômicos, sociais e políticos e se apresenta idealmente como uma burguesia revolucionaria, democrática e nacionalista, segundo o modelo de Revolução Burguesa.

Como consequência dessa simulação temos que a Primeira República preservou as condições existentes no Império, ou seja, a coexistência de duas Nações: uma que se incorporava à ordem civil constituída pela rala minoria de mais ou menos iguais e outra que estava dela excluída, de modo parcial ou total composta pela grande maioria de mais de quarto quinto que constituía a nação real.

As representações ideais da burguesia eram um adorno, um objeto de ostentação, um símbolo de modernidade e de civilização.

Quando outros grupos se puseram em condições de cobrar essa identificação simbólica, a burguesia se mostrou predominantemente reacionária, ultraconservadora e reagiu dentro da tradição do mandonismo oligárquico. Como exemplo, temos o tratamento violento dado as greves operárias e ao movimento anárquico sindicalista no início do século $\mathrm{XX}$; a repressão armada às aspirações democráticas das massas urbanas e rurais em meados do século $\mathrm{XX}$, os processos de fechamento e ilegalidade reservados as câmaras representativas estaduais e federais, aos partidos e grupos de esquerda e a interdição da democracia participativa pela via do voto popular. Os golpes de Estado financiados pela burguesia comercial, industrial e financeira- nacional e internacional- contaram com o apoio de diferentes setores da so- 
ciedade civil, utilizaram-se do aparto estatal ora pelos braços das forças armadas, do legislativo e do judiciário. Em todos a grande mídia se prestou ao papel de propaganda ideológica dos interesses hegemônicos e contra as classes populares.

Assim se sucedeu na República brasileira em 1937, em 1964 e em 2016. Em todos estes momentos os movimentos sociais e as manifestações populares que clamavam por uma ampliação da participação dentro da ordem democrática foram tratados com violência e repressão convertendo o exercício da política em "caso de polícia”.

Portanto, sempre estivemos diante de uma burguesia conservadora que tendia a circunscrever a modernização no âmbito formal e institucional objetivando criar as condições para o crescimento da atividade econômica e que nunca se empolgou com os destinos da Nação como um todo, nem para revolucioná-la de alto a baixo nem tampouco para reformá-la gradativamente incluindo estratos sociais historicamente excluídos, tais como: índio, negro, trabalhadores do campo e da cidade.

Fernandes entende que além desse ponto morto que vinha de dentro para fora existia um outro eu vinha de fora para dentro (1975, p. 206). A transição para o século XX e todo o processo de industrialização que se desenvolve até a década de 1930 fazem parte da evolução interna do capitalismo competitivo. O eixo dessa evolução estava no esquema de exportação e importação sob a égide da economia neocolonial. A influência modernizadora externa se circunscrevia às fronteiras da difusão de valores, técnicas e instituições instrumentais para a criação da economia capitalista competitiva satélite, integrada e dependente. $\mathrm{O}$ modo de produção capitalista e a dominação burguesa não pretendiam acordar o homem nativo para os sonhos de revolução nacional e de libertação da dominação externa. $\mathrm{O}$ impulso modernizador foi induzido por forças externas que se circunscreviam a esfera da modernização econômica alinhada ao capitalismo global na transição do modelo competitivo para o monopolista.

Nesse sentido, existia uma convergência de interesses da burguesia interna e externa que fazia da dominação burguesa nacional uma fonte de estabilidade econômica e política essencial para o crescimento e alinhamento às diferentes temporalidades do capitalismo internacional. 
Fernandes dirá:

A dominação burguesa se associava a procedimentos autocráticos, herdados do passado ou improvisados no presente [...] neutralizava a formação e a difusão de procedimentos democráticos [...] na verdade eles tinham existência legal ou formal, mas eram socialmente inoperantes (FERNANDES. 1975, p. 207)

Neste sentido, a passagem do modo de produção agrário exportador para o urbano industrial competitivo e depois monopolista não foi marcada por forças em confronto histórico, em luta pelo controle do Estado tendo em vista alargar o alcance das mudanças sociais. Pelo contrário, o Brasil moderno é marcado por uma associação entre o velho e o novo, entre a preservação e renovação das estruturas oligárquicas de poder modernizando as condições de acumulação primitiva do capital e expandindo-as para as esferas comercial, industrial e financeira.

No entanto, o regime de classes, a divisão social e internacional do trabalho, a segmentação-hierarquização e estratificação do mercado, a diferenciação dos processos de produção-circulação e consumo capitalista têm sua lógica, à qual as burguesias nacionais não conseguem escapar e nem controlar completamente.

Os fundamentos axiológicos legais e formais da ordem social foram extraídos de uma ordem capitalista idealizada que se materializou, em alguma medida, nos países ocidentais centrais, mas esses fundamentos serviam apenas de arsenal ideológico e utópico de situações ocorridas nas nações hegemônicas centrais. As burguesias periféricas não tinham a pretensão de saturá-lo dentro da ordem nacional e, por isso, interditaram espaços de oposição, não dialogaram com grupos que clamavam por mudanças sociais e silenciaram, pelo poder da dissuasão e pela repressão policial, todos as manifestações que não partiram "de cima".

Isso explica a extrema intolerância diante de manifestações potenciais e autônomas do movimento dos trabalhadores, das periferias das cidades, dos movimentos sociais no campo. Essa intolerância fechou as possibilidades de uma inserção capitalista burguesa segundo a ordem democrática. $\mathrm{O}$ que alcançamos realizar foi uma democracia 
restrita, aberta e funcional só para os grupos que compõem uma pequena fração da dominação burguesa.

A revolução burguesa que ocorre tardiamente nos países periféricos é uma revolução difícil e com implicações políticas, econômicas e socioculturais adversas pois ela se enverga às dinâmicas instauradas pelos países capitalistas centrais.

Florestan dirá que a alternativa de inserção dessas burguesias será, a um tempo, de "parteiras e ama secas" considerando que a redução do campo de atuação das burguesias nacionais aparece como uma conexão histórica do tipo de transformação que o capitalismo delega ao capitalismo tardio, periférico e dependente (1975, p. 214).

Gorender (1987) aprofunda e critica esta chave de interpretação e diz:

[...] as massas trabalhadoras da cidade e do campo vêm pagando um preço altíssimo a fim de que a economia capitalista consiga funcionar e expandir no país. $\mathrm{O}$ que, todavia, não deve nos levar a idealizar o que se passou nos países do capitalismo clássico [...]. Todo processo de formação do capitalismo, onde quer que haja ocorrido, foi tormentoso, difícil e extremamente pesado para as massas trabalhadoras, os operários e camponeses $(1987$, p. 256)

Nesta chave interpretativa, alguns momentos históricos intermitentes podem ser tomados como paradigmáticos de possibilidades de viragens e de pactuação diferenciada entre a ordem capitalista, o poder burguês e a democracia participativa no Brasil.

$\mathrm{O}$ primeiro momento situa-se no período da Independência (1808) quando se acalentou o ideal de construção de um Estado nacional emancipado da ordem colonial portuguesa. Ele se deu sob a égide do liberalismo enquanto a ideologia que sustentou a força cultural da revolução nacional (FERNANDES, 1975, p. 38). O paradoxo é que a revolução nacional política não trouxe consigo uma revolução econômica e social que forjasse ideias de autonomia e rompesse com a grande lavoura como polo dinâmico da economia e nem contou com revoluções sociais de construção da sociedade regida pelo trabalho assalariado e pela ruptura das relações escravocratas. Assim, a autonomia política não foi o resultado e nem constitui um fator de transformação econômica e social de natureza revolucionária. 
As relações sociais seguiram regidas pelo patrimonialismo, pela grande lavoura, pela economia agroexportadora e pelo trabalho escravo. Os agentes dinâmicos da Independência foram os grandes senhores de terra, os latifundiários que incomodados com a drenagem dos lucros da produção colonial da colônia para a metrópole, exigiam maior participação na riqueza decorrente desse processo econômico. Entretanto, o senhor do engenho gravitava no ambiente cultural conservador que lhe favorecia e, além disso, ocupava uma posição marginal no processo de mercantilização da produção agroexportadora e não pode ser subsumido como antecessor do empresariado moderno e construtor da sociedade de classes. (FERNANDES, 1975, p. 96)

O segundo momento de possibilidades de rupturas seria a Abolição da Escravatura e o advento da República (1860- 1889 a 1950) - que se caracterizam pela formação no Brasil da ordem social competitiva e sua expansão participativa na economia capitalista.

Para Fernandes (1975), o fim do Império e o começo da República contém os germes para se buscar na historiografia brasileira a forma de poder e dominação burguesa. Esse período não pode ser tratado como a crise do poder oligárquico, mas o início de uma transição que inaugura, sob a hegemonia inicial da oligarquia, uma recomposição das estruturas de poder pela qual se configuram historicamente no Brasil o poder e a dominação burguesa.

Essa recomposição marca nossa entrada na modernidade referenciada pela Abolição da Escravatura (1888), Proclamação da República (1889) e inquietações da era senhorial que entrecortaram a década de 1920 e impulsionam o advento da era burguesa e da sociedade de classes que tem na Revolução de 1930 um momento paradigmático.

Em cerca de meio século se desagregou formalmente a ordem social escravocrata e senhorial face aos requisitos do capitalismo internacional. No entanto, o fim da escravidão, a crise da ordem senhorial e a incorporação de elementos básicos da ordem social competitiva não trouxeram impulsos revolucionárias, repetindo um processo acomodatício tal como ocorreu no movimento da Independência. A emergência de um novo setor representado pela economia urbano comercial e industrial de padrão capitalista abrigou possibilidades de crescimento econômico, expansão territorial da burguesia, desenvolvi- 
mento da malha ferroviária de circulação e escoamento de mercadorias, ampliação dos negócios para o interior do país aliada à rota do café. Desta forma, a oligarquia não perdeu a base de poder que lograra antes, como e enquanto aristocracia agrária e, além disso, encontrou condições para enfrentar a transição modernizando-se e desdobrando oportunidades novas.

A crise de 1929 acarretada pela quebra da bolsa de valores de Nova Iorque e a depressão econômica dela decorrente produziu nos países capitalistas ocidentais centrais um longo período de recessão econômica, altas taxas de desemprego, quedas drásticas no produto interno bruto. A oligarquia brasileira foi afetada pois a economia cafeeira se ancorava na exportação.

Candido (2013) entende que este momento marca a modernização do Brasil mediante a transferência de liderança da oligarquia de base rural para a burguesia de base industrial, o que corresponde à industrialização e que teve como eixo a Revolução de 1930 pois foi somente partir dessa que o operariado viu-se em condições de assumir a iniciativa política de modo mais efetivo (embora tutelado pelo governo) e o empresário alçou o primeiro plano mesmo tendo sua ação mesclada pela mentalidade e pelas práticas da oligarquia. $\mathrm{O}$ populismo foi o mecanismo utilizado para ajustar, segundo uma métrica própria, o arcaísmo e a modernidade (CANDIDO, 2013).

Foi um período marcado por greves no campo e na cidade, pela emergência da classe trabalhadora e por curtos e frágeis períodos de democracia a partir dos quais se estabeleceu novos marcos para os direitos civis, políticos e sociais (MARSHALL, 1967). Como exemplo, a Consolidação das Leis Trabalhistas (CLT) com um escopo de cobertura social restrita aos trabalhadores urbanos com carteira assinada, ou seja, uma parcela muita pequena do povo brasileiro alçou o estatuto de cidadão segundo uma concepção burguesa. É importante lembrar que este período é entrecortado pela ditadura do Estado Novo que cassou direitos sociais e políticos de 1937 a 1945. Deste modo, na ruptura da ordem senhorial, os papéis sociais estratégicos antes reservados ao fazendeiro de café, foram subsumidos pela burguesia comercial, industrial e financeira e pelo imigrante subsidiado e participe da política de embranquecimento da nação (OLIVEIRA VIANA, 1956). O escravo liberto, os camponeses expulsos do campo e os trabalhado- 
res urbanos resistiram e reagiram aos papéis secundários a eles atribuídos na emergência da sociedade de classes, mas foram violentamente reprimidos e silenciados.

O terceiro momento se refere a década de 1950 em diante e se caracteriza pela erupção do capitalismo monopolista e inserção do pais na economia capitalista globalizada, com forte hegemonia do capitalismo financeiro internacional. Esse momento é novamente entrecortado pelo golpe civil-militar de 1964 a 1984 que desprende ainda outra vez o papel restrito que a burguesia nacional desempenha como agente modernizador - na esfera do econômico e político - não permitindo a realização da democracia capaz de estender os direitos formais e consubstanciá-los nas condições concretas de existência.

A burguesia nacional se associa a procedimentos autocráticos que marcam nitidamente "a ordem com o progresso" e qualificam a consolidação conservadora da dominação burguesa no Brasil que aprofundou ainda no século XX - a desigualdade social, o controle político e ideológico, a dependência financeira ao capital internacional e a subserviência as diretrizes das agências internacionais de controle dos estados nacionais segundo a lógica do grande capital.

O quarto momento está em curso e em decorrência da contemporaneidade dos processos o denominarei de Golpe de 2016.

Nos quatro períodos destacados a burguesia nacional definiu como inimigo comum: nos séculos XVI e XVII o índio nativo; nos séculos XVII ao XIX o escravo negro; no século XX e XXI o trabalhador assalariado e semi-assalariado do campo, da cidade e além de perdurar e aprofundar os marcadores dos séculos passados, ou seja, não criar condições de inserção do índio, do negro e das comunidades tradicionais ribeirinha, quilombolas e da floresta na sociedade de classes.

Os períodos de crises cíclicas no modo de regulação do capitalismo burguês nos países centrais coincidem com os curtos e frágeis períodos em que as burguesias nacionais, abandonadas pelo capitalismo global, se viram lançadas a própria sorte e ensaiaram pactuações com setores da sociedade nacional. Esses períodos, na República, podem ser mais ou menos demarcados como: 1930/1937, 1945/1964, 1985/2016, nos quais se ensaiou possibilidades de um projeto de desenvolvimento nacional, se amplificou a consciência crítica sobre a inserção tardia e dependente do país no capitalismo global e se conside- 
rou a existência de uma população nacional que poderia incrementar um mercado interno e ser dele beneficiada. Foram momentos em que a população brasileira, as grandes massas de trabalhadores e trabalhadoras resistiram, atuaram e vislumbraram participar dos processos de produção, circulação e consumo de bens materiais e imateriais. Esses interregnos de exercícios democráticos foram férteis para os movimentos de organização sindical, a pluralidade partidária, a retomada do direito de voto, o alargamento dos marcos jurídicos regulatórios dos direitos sociais e a instauração de práticas afirmativas de identidades culturais plurais.

Assim, mesmo identificando que revolução burguesa no Brasil se impôs de cima para baixo como uma contrarrevolução dentro da ordem em que as classes populares tiveram que se assujeitar sob um rígido esquema repressivo; mesmo reconhecendo que a industrialização se deu contando com a violência institucional do Estado e com exclusão e repressão social produzindo transições pífias e acomodatícias; é possível registrar conquistas populares nos interstícios democráticos.

Na política educacional, desprendemos no período de 1930 a 1945 o Manifesto dos Pioneiros da Educação Nova que representou um primeiro esforço de organização de uma instrução adequada a estrutura da sociedade moderna e que conclamava o Estado na condução da educação pública, escola única para ambos os sexos, laicidade, gratuidade e obrigatoriedade. No período de 1945 a 1963, sob disputas acirradas entre os grupos sociais que reclamavam a organização do sistema público de educação e os grupos que vislumbravam o acesso aos recursos públicos subsidiando a educação privada - em defesa da primazia da família sobre a educação dos filhos e a escolha da escola foi ratificado a primeira Lei de Diretrizes e Bases da Educação Nacional (LDB) 4024/1961 que tratou a Educação como uma política de Estado com base nos princípios constitucionais. No período de 1985 a 2016, muitas foram as conquistas a começar pela Constituição de 1988 que pela primeira vez acena:

A educação, direito de todos e dever do Estado e da família, será promovida e incentivada com a colaboração da sociedade, visando ao pleno desenvolvimento da pessoa, seu preparo para o exercício da cidadania e sua qualificação para o trabalho. (BRASIL, 1988, Art. 205). 
Ela define ainda a cesta básica dos direitos sociais entendendoos como concomitantes e integrados no combate à pobreza e as desigualdades:

São direitos sociais a educação, a saúde, a alimentação, o trabalho, a moradia, o lazer, a segurança, a previdência social, a proteção à maternidade e à infância, a assistência aos desamparados (BRASIL, 1988, Art. 6)

À Carta Magna se seguiu a LDB 9394/1996, Plano Nacional de Educação (PNE) de 2001- 2010, PNE 2014-2024 que apontam metas a serem alcançadas para a Educação Nacional tendo em vista universalizar acesso, permanência e qualidade do ensino fundamental, ampliar gradativamente o escopo da escolarização obrigatória, erradicar as muitas formas de analfabetismo, vincular recursos públicos às políticas sociais, criar programas interministeriais de combate à fome, pobreza e desigualdade, criar programas de distribuição de renda etc.

É importante destacar que em todos estes momentos o Estado foi disputado pelos grupos hegemônicos como instância fundamental e garantidora da interface entre as dinâmicas econômicas do capitalismo interno e externo e a ancora institucional que confere legitimidade ao poder burguês. Nesse sentido, é possível apontar que a revolução burguesa no Brasil é uma contra-revolução-burguesa, pois o conceito aplicado a realidade se afigura como um contrassenso heurístico.

Florestan vai apontar que a burguesia na periferia é incapaz de conduzir uma revolução democrática nacional, mas "não deixa de permanecer no centro do controle do poder econômico, social e político de suas respectivas sociedades de classe” (1975, p, 144)

Gorender (1987) é mais crítico e diz:

A burguesia brasileira falhou na sua missão histórica, uma vez que não instaurou a democracia e não realizou um desenvolvimento econômico independente. Nada há, pois, a esperar dela. [...]. Nenhuma credibilidade, absolutamente nenhuma, é cabível conferir ao suposto potencial revolucionário da burguesia no Brasil (p. 258).

Do ponto de vista da democracia representativa, o Golpe de 2016 não se justifica pelas pedaladas fiscais da Presidente Dilma Roussef, cujo processo ainda não reuniu provas suficientes e nem conseguiu provar a improbidade administrativa ou o crime doloso que leva- 
riam a um impeachment. Também não se sustenta na bandeira de "fim da corrupção na política” incitado pela Federação das Indústrias do Estado de São Paulo (Fiesp). A comoção nacional que tomou as ruas das principais cidades do país, paramentadas de verde e amarelo, teve como alvo fermentar o ódio contra o Partido dos Trabalhadores e contou com a cooptação da grande mídia e o apoio de estratos conservadores da população, tais como: as bancadas da bíblia, do boi e da bala (MEDEIROS e FONSECA, 2016).

Se fosse pela corrupção na política, o impeachment e a Lava Jato já teriam derrubado muitas famílias de políticos brasileiros que há décadas realizam pedaladas fiscais e exercitam a apropriação privada dos recursos públicos tendo em vista o enriquecimento pessoal. Refiro-me as famílias de Collor de Melo, Antônio Carlos Magalhães, Paulo Maluf, Jose Sarney, Aécio Neves, Fernando Henrique Cardoso, Renan Calheiros, Michel Temer, Geraldo Alckmin, para citar alguns recentes.

O Golpe de 2016 foi uma resposta a incapacidade das elites econômica e política brasileiras se manterem no poder por meio da democracia representativa do voto popular. Elas perduram por meio de golpes de Estado.

O modelo capitalista burguês imposto de cima para baixo, com resquícios da ordem social patrimonialista e autoritária que promoveu a industrialização no país e que contou com a coação e coerção do aparato do Estado e com exclusão política e social da maioria da população vinha se mostrando combalido e dando sinais de esgotamento desde as eleições de 2002 quando o candidato à Presidência da República, pelo Partido dos Trabalhadores (PT), Luís Inácio Lula da Silva, derrotou, pelo voto popular, o candidato Jose Serra, do Partido da Social Democracia Brasileira (PSDB). Na eleição de 2006, novamente Lula ganha as eleições e derrota o candidato Geraldo Alckmin, do PSDB.

Na eleição de 2010 a candidata à Presidência Dilma Roussef, pelo PT e apoiada por Lula, ganha as eleições presidências pelo voto e derrota o candidato Jose Serra do PSDB. Em 2014 Dilma Roussef é reeleita e derrota o candidato Aécio Neves do PSDB.

Segundo Bichir (2010) o sucesso eleitoral do PT se deve, principalmente, pela intervenção estatal contra a pobreza e desigualdade 
enfrentadas por meio de políticas sociais focalizadas nos grupos mais vulneráveis da população, tais como: os programas de transferência condicionadas de renda; e as políticas sociais universais de acesso à educação e saúde. Os índices recortes alcançados pelo voto popular se assentam no tripé formado pelo "Programa Bolsa Família, o aumento real do salário mínimo e o aumento do acesso popular ao credito" (BICHIR, 2010, p. 126).

Lula vem de origem pobre, do nordeste de Pernambuco e ainda menino migrou com sua família para São Paulo em busca de melhores condições de vida e de trabalho. Foi metalúrgico, sindicalista, participou das grandes greves operarias do ABC Paulista e da fundação do Partido dos Trabalhadores. Governou de 2003 a 2010 e teve como marca de seus governos dois programas sociais reconhecidos pela Organização das Nações Unidas (ONU) como programas que possibilitaram a saída do país do mapa da miséria. São eles: o Bolsa Família e o Fome Zero.

Dilma Roussef é economista oriunda de família de classe média alta de Belo Horizonte, Estado de Minas Gerais, na juventude adere ao socialismo e participa de vários grupos políticos de esquerda que partiram para a luta armada contra a ditadura civil militar instaurada pelo Golpe de 1964. Foi presa, torturada e permaneceu em reclusão durante 3 anos (1970 a 1972). Quando eleita se apresentou publicamente como mulher de esquerda, presa política, separada e mãe de uma filha.

Diferentemente de Lula e Dilma, os quatro candidatos do PSDB derrotados por meio do voto popular, são herdeiros dos percursos políticos que marcam a tradição de revolução burguesa, tal como a descrevemos, e se vinculam a grupos hegemônicos da burguesia comercial, industrial e financeira nacional e internacional.

Neste sentido, é possível sustentar que o Golpe de 2016 é um golpe contra:

1 - Nossas frágeis, curtas e sempre interrompidas experiências democráticas,

2 - A chegada de outros espectros da população brasileira ao poder de Estado,

3 - O perigo que representa para o ideário econômico e político do Brasil a associação do poder do Estado brasileiro não mais às 
elites agrárias ou burguesas comerciais, industriais e financeiras, urbanas e rurais, alinhados aos interesses do grande capital produtivo e financeiro,

4 - A tomada do aparato do Estado por estratos sociais historicamente excluídos, estigmatizados e perseguidos tais como: trabalhadores, pobres, migrantes, nordestinos, socialistas, sindicalizados. Ou mulheres, socialistas, presas políticas, que participaram da luta armada contra o aparato do Estado brasileira e que não simulam o ideal de família tradicional.

5 - A destinação dos recursos vinculados do Estado às políticas sociais endereçadas ao povo brasileiro e não a acumulação capitalista e burguesa.

Lula e Dilma se distanciam da imagem e do poder exercitado pelas elites nacionais tradicionais. O Golpe de 2016 é um golpe contra a democracia, contra a chegada do povo brasileiro no poder de Estado e contra o exercício de participação política das massas na ordem democrática e no capitalismo global.

Finalizo com um chamamento à luta, resistência, organização e participação direta da população na construção da ordem social democrática lembrando que:

A questão da democracia ultrapassa de longe a problemática burguesa. A democracia interessa a toda a Nação e a Nação não é a burguesia [...]. Assim como a chave política do autoritarismo não se encontra apenas na burguesia, mas principalmente no Estado, a chave da democracia não se encontra no Estado, mas na própria sociedade civil (ALMEIDA, 1987, p. 227-8).

O povo brasileiro não é composto por grupos minoritários, ele adensa a grande maioria da população e pode se organizar e compor uma grande frente parlamentar das bancadas da cidadania. (BAVA, 2016)

\section{REFERÊNCIAS}

ALMEIDA, Paulo R. O paradigma perdido. In D'INCAIO, Maria A. Saber militante. Ensaios sobre Florestan Fernandes. RJ: Paz e Terra, 1987. p. 209-229. 
BAVA, Sílvio C. Bancadas da cidadania. In Le monde diplomatique. Brasil, Ano 9, nº. 108, p. 3, julho 2016.

BICHIR, Renata M. O Bolsa Família na Berlinda? In Novos Estudos. CEBRAP, nº. 87, p. 115-129, junho 2010.

BRASIL. Constituição da República Federativa. Brasília: DF, 1988.

CANDIDO, Antônio. Para conhecer o Brasil. In Blog da Boitempo, noticia 17/05/ 2013. <https://blogdaboitempo.com.br/2013/05/17/antonio-candido-indica-10-livros-para-conhecer-o-brasil/> Acesso em: 22 set. 2018

FERNANDES, Florestan. A Revolução Burguesa no Brasil. Ensaio de interpretação sociológica. RJ: Jahar Editores, 1975.

GORENDER, Jacob. A revolução burguesa e os comunistas. In D

INCAIO, Maria A. Saber militante. Ensaios sobre Florestan Fernandes. RJ: Paz e Terra, 1987, p. 250-262.

MARSHALL, T. H. Classe social, cidadania e status. RJ: Zahar, 1967.

MEDEIROS. Etora e FONSECA, Bruno. Bíblia, Boi e Bala: um raio$\mathrm{X}$ das bancadas da Câmara. In. Pública. Agência de Jornalismo Investigativo. 〈https://apublica.org/> Acesso em: 18 fev. /2016.

OLIVEIRA VIANA, Francisco J. de. Evolução do Povo Brasileiro. $4{ }^{a}$. Ed. RJ: Editora Jose Olympio, 1956.

PRADO JUNIOR, Caio. Formação do Brasil contemporâneo. Colônia. 7a. Ed., SP: Editora Brasiliense, 1973.

RIBEIRO, Maria Luiza S. História da Educação Brasileira. Organização Escolar. SP: Editora Moras, 1981. 


\section{$\mathrm{v}$ \\ O GOLPE DE 2016, SUAS RAÍZES. PERSPECTIVAS DA RESISTÊNCIA*}

Qeginaldo P. Aroraes

O Brasil do golpe é herdeiro legítimo de várias transformações estruturais, daquelas que vão produzindo e acumulando efeitos ao longo do tempo. O Brasil do golpe não mostra apenas as perversões de quem o desfechou ou dele se beneficia. A própria necessidade de dar o golpe indica, de modo oblíquo, aquilo que se transformou nos subterrâneos da sociedade. Isto é, mostra as razões do golpe, aquilo que se procura abafar. $\mathrm{O}$ golpe não é apenas uma tara ou fruto da desrazão. É, em certo sentido, uma necessidade.

Das transformações estruturais que marcaram o Brasil contemporâneo, a mais óbvia e conhecida é a passagem de um país rural e agrário para outro, urbano e industrial. Dois surtos se registraram no pós-guerra. Primeiro, os anos 1950, quando sobre a indústria de base capitaneada pelo estado - siderurgia, energia elétrica e petróleo - se ergueu uma constelação de modernas manufaturas de bens duráveis e semiduráveis, combinando-se com a já existente indústria de bens populares (têxtil, vestuário, alimento). Depois, o surto do "milagre", mais acelerado e mais polarizador - um crescimento que parecia inviável mas se revelou tetricamente real. Um crescimento que não se deu apesar da concentração de renda, mas, precisamente, através dela.

Como dano colateral desses surtos, surgiu um país de contrastes e conflitos latentes - ainda que nem sempre claros e manifestos. Muitas vezes abafados pela repressão endêmica ou pela "esquecimento" programado. Nos campos, muita gente sem terra, muita terra sem gente - a quimificação e mecanização da agricultura se deu através de um sistema de crédito rural que ajudou a concentrar uma propriedade já terrivelmente concentrada. Nas cidades, milhões de brasileiros fo-

DOI - 10.29388/978-85-53111-28-2-0-f.79-88 
ram empilhados, tornando-se citadinos sem virar cidadãos. Próximos de tudo, longe de tudo. Muita gente sem teto, muito teto sem gente, muita gente sem voz. Mas com voto, pelo menos potencial.

E talvez esta tenha sido uma das transformações mais preocupantes para a casa grande - a relevância cada vez maior e mais incômoda da plebe votante. Na última eleição da república velha, a de 1930, apenas 5\% dos brasileiros participaram do pleito. Trinta anos depois, na última antes do golpe militar, esse percentual chegara a quase 20\%. Na eleição que antecedeu o golpe parlamentar-jurídicomidiático, dois terços da população foram chamados a dizer que tipo de país queriam, identificando suas aspirações em figuras claramente opostas. Esse processo de ampliação dos jogadores é, sem dúvida, uma pedra no sapato da oligarquia reinante.

Sim, oligarquia reinante é a expressão cabível, porque através de todas essas mudanças, algo sobreviveu praticamente intocado. A desigualdade. De renda, de propriedade e de poder. O Brasil do golpe de 1964 era uma pirâmide. O Brasil de hoje continua sendo. $\mathrm{Ou}$ um edifício de estratos bem marcados. Um andar superior, o dos $15 \%$ ou $20 \%$ que ganham muito, pagam pouco imposto, controlam os fios dos poderes, inclusive do chamado quarto-poder. Depois, um enorme e diversificado andar de baixo que sua a camisa, sustenta as finanças do estado e recebe o essencial para seguir entregando o suor e reproduzindo a plebe. E no meio desses extremos, dois ou três estratos sonâmbulos, daqueles que oscilam. Na maior parte das vezes, manifestam o medo de serem atingidos ou de serem confundidos com os de baixo. $\mathrm{O}$ medo se transforma corriqueiramente em desprezo e ódio. Na maior parte das vezes, também, alimentam a ilusória pretensão de serem recebidos nas festas dos palácios. O que se transforma, corriqueiramente, em servilismo e lisonja. Ou seja, a pirâmide não estratifica apenas as rendas, propriedades e poder - estratifica também as mentes, corações e comportamentos cotidianos. E afeta, claro, o mapa das cidades - designando o lugar de cada um.

Durante uns doze anos, essa estrutura de guetos sofreu pequenos arranhões. Pequenos para os custos da casa grande, mas de enorme significado para o andar de baixo. Para alguns dos andares mais inferiores, as políticas de socorro à pobreza eram quase a diferença entre morrer e sobreviver. Para outros, a oportunidade de frequentar 
uma universidade. Ou de viajar de avião. Até mesmo, vejam que ousadia, andar pelas ruas dos shopping centers.

Mas os arranhões eram grandes e ameaçadores para a gula dos habitantes do topo e para e os temores dos estratos médios. Essa percepção foi-se consolidando e se tornando rancorosa, diante dos sucessivos fracassos de candidatos que tentavam vender o peixe do retrocesso. Rancori cuidadosamente alimentado e canalizado pela formidável manufatura de sentimentos e valores concentrada em redes de rádio, TV e púlpitos (e de púlpitos televisados!).

Mas existe ainda outro agente nesse jogo de confrontos - algo que nem sempre estimamos na devida conta. O novo país - aquele que já fora o país do futuro - deixava de ser um pária utilizado como exemplo de inviabilidade civilizatória e se transformava em estimulante ponto de apoio para o quintal dos Estados Unidos, uma América Latina insurgente. Mais ainda, ousava opinar sobre coisas de gente grande, como o acordo nuclear com o Irã. Ou ensaiava organizar uma estrutura de crédito e financiamento alternativa à do império - o banco dos BRICs. Diante dessa ousadia, ao andar de cima do edifício Brasil se somou, sutil, mas determinante, o braço do império. Juntos, a Casa Grande e a Casa Branca jogaram as cartas que precisavam para produzir um novo enredo, um novo arranjo de poder.

\section{Doutrina do Choque - a direita produz o caos para impor sua política}

Faz alguns anos, a escritora canadense Naomi Klein publicou um livro de grande interesse para entendermos o tempo em que vivemos. Chama-se A Doutrina do Choque.

O livro mostra em detalhes várias situações em que um mesmo modo de operar foi utilizado por forças reacionárias para impor "ajustes" que os cidadãos rejeitariam em condições normais. O modo de operar é aproveitar ou criar um clima de choque.

Ela diz que esse é o "método preferencial para promover os objetivos das corporações: aproveitar os momentos de trauma coletivo e implementar uma engenharia social e econômica radical"

Ela compara essa técnica - utilizada para forçar multidões, comunidades, países inteiros - com a técnica de submissão aplicada aos 
prisioneiros, torturados para fornecer informação aos "serviços de segurança”. São técnicas desenvolvidas durante décadas por equipes de "pesquisadores da tortura", ligados a organizações criminosas de estado, como a CIA americana e a polícia secreta israelense.

É muito útil para nós, neste momento, ouvirmos a palavra de Klein:

A tortura, ou "interrogatório coercitivo" no linguajar da CIA, é um conjunto de técnicas destinadas a colocar os prisioneiros em estado de profunda desorientação e choque, de modo a obrigá-los a fazer concessões contra a própria vontade. A lógica que norteia os procedimentos foi elaborada em dois manuais da CIA que se tornaram públicos na década de 1990. Neles, está explicado que o melhor modo de quebrar as "resistências" é promover rupturas violentas entre o prisioneiro e a sua habilidade para compreender o mundo à sua volta.(36) Em primeiro lugar, privando-o de qualquer tipo de contato (utilizando capuz, tapa-ouvidos, algemas, total isolamento), e depois bombardeando seu corpo com estímulos exagerados (luz estroboscópica, música estridente, pancadas, eletrochoque). O objetivo desse estágio "suave" é provocar uma espécie de furacão dentro da mente: prisioneiros ficam tão regredidos e assustados que perdem a capacidade de pensar racionalmente e proteger os próprios interesses. É nesse estado de choque que a maioria dá aos interrogadores aquilo que estão querendo - informação, confissão, renúncia a crenças anteriores.

E ela esclarece: aquilo que funciona com esse indivíduo preso funciona também quando aplicado a coletivos, a grandes comunidades, como se elas também estivessem aprisionadas e submetidas a tratamento de interrogatório forçado:

Como o preso aterrorizado que entrega os nomes de seus companheiros e renuncia à própria fé, as sociedades em estado de choque frequentemente desistem de coisas que em outras situações teriam defendido com toda a força.

A doutrina do choque imita esse processo de forma meticulosa, procurando atingir numa escala maciça o que a tortura faz individualmente nas celas de interrogatório. 
Em 1996, um documento da defesa americana já resumia essa técnica, utilizada em invasões, sabotagens e processos através dos quais o governo americano, diretamente ou através de forças manipuladas, tentava impor suas metas a outros países:

"Domínio significa a capacidade de afetar e dominar a vontade do adversário, tanto fisica como psicologicamente. Domínio físico inclui a capacidade de destruir, desarmar, perturbar, neutralizar e tornar impotente. Dominação psicológica, a capacidade de destruir, derrotar e castrar a vontade de um adversário para resistir; ou convencer o adversário a aceitar nossos termos e objetivos sem usar a força. $O$ alvo é a vontade do adversário, sua percepção e compreensão. O principal mecanismo para se atingir este domínio é impor condições suficientes de "Choque e pavor" sobre o adversário para convencer ou obrigar a aceitar nossos objetivos estratégicos e objetivos militares. Devem ser empregadas a mentira, confusão, informação falsa e desinformação, talvez em quantidades maciças." [Shock and Awe Achieving Rapid Dominance - do Defense Group Inc. for The National Defense University]

Atenção, leitor. Até agora falamos mais de "aproveitar a crise" para impor políticas que, em tempos normais, seriam recusadas. Mas no exemplo do prisioneiro, não se trata apenas de aproveitar a crise, mas de produzir a crise. Também na vida política se faz assim.

Vamos lembrar o que dizia um famoso guru neoliberal, Milton Friedman, amigo e conselheiro de Pinochet e dos militares argentinos:

"Somente uma crise - real ou percebida como real - produz mudança de fato. Quanto essa crise ocorre, as ações dependem de idéias que estão disponíveis no momento. Acredito que essa é a nossa função básica: desenvolver alternativas para as políticas existentes, manter essas alternativas prontas e disponíveis até que aquilo que antes parecia politicamente impossível se torna politicamente inevitável". (Milton Friedman - Prefacio á edição 1982 de Capitalism and Freedom, University of Chicago Press) 
O que aconteceu no Chile, laboratório de Friedman, não foi um "aproveitamento" da crise. Foi a produção deliberada de uma crise, através de sabotagem ampla, geral e irrestrita ${ }^{1}$.

No Chile, como no Brasil, na Venezuela, no Egito, na Ucrânia... em muitos lugares do mundo, as grandes corporações e o governo americano produziram a crise, sabotaram o país para criar o ambiente que desarvorou a resistência e impôs as reformas que eles pretendiam.

Do outro lado, o desafio da resistência é perceber como evitar a produção da crise encomendada, como enfrentar as armadilhas dos torturadores, que possuem armas, recursos, mídia, aparatos de estado. Como?

\section{É possível uma resposta à estratégia golpista do choque?}

Resumindo a equação de Naomi Klein: a tática de dominação dos golpistas mundo afora é a tática do choque, aproveitar os momentos de trauma coletivo para aplicar sua política. Mais do que isso, diz ela: eles criam criar o trauma coletiva, não esperam simplesmente que ele ocorra.

Por isso, Naomi Klein compara as técnicas de dominação política de massas - aquelas que estamos vivendo hoje - com a técnica dos interrogatórios promovidas pelos torturadores. A vantagem do policial, e sua principal arma, é destruir mentalmente o preso. Para isso, isolá-lo de tal maneira que não saiba o que ocorre lá fora - com seu movimento, seus companheiros, suas crenças. Depois de algum tempo, desmoralizado, desmotivado, descrente, ele cede. Desiste de resistir.

Essa foi a técnica do ataque-choque que viveu o Brasil durante anos. Acelerou-se em 2013. E segue sendo executada. Lá em 2013, as forças da direita (local e internacional) perceberam os pontos fracos do governo e investiram fortemente em "grupos de base" para desestabilizá-lo. Sequestraram a palavra dos pequenos grupos de esquerda que manifestavam descontentamento com a lentidão das reformas e com as distorções do processo, com aquilo que tardava a chegar. A li-

\footnotetext{
${ }^{1}$ Se quiser alguns detalhes veja essa estória: http://brasildebate.com.br/chile-brasil-e-as-reformas-a-prova-de-mudancas-politicas/.
} 
derança "das ruas" foi transferida para empresas promotoras de eventos fortemente midiáticas e fartamente financiadas pela oligarquia MBL, Vem prá Rua, Revoltados Online, as marcas e rótulos pululam.

A grande mídia foi a caixa de eco dessa campanha, que envolve políticos, policiais, promotores e juízes. Nacionais e internacionais. Desde aquela época, os círculos dominantes que se sentiram incomodados com a evolução do país resolveram que era hora e era possível começar a virar o jogo. $\mathrm{O}$ governo reformista - lento, dividido, acomodado - tinha muitos pontos fracos. Era o momento.

A única saída que restava ao campo progressista - em sentido amplo - seria reverter essa situação de cerco. Romper o próprio cerco, a estratégia de isolamento, divisão e confusão. A primeira regra seria quebrar a vantagem dos torturadores: jamais permitir o isolamento, o desmonte da confiança e das crenças. Com desvantagem nesse campo, os demais ficam comprometidos.

Mas é preciso levar em conta um outro processo lento mas cumulativo que marcou os primeiros quinze anos do milênio. Os "arranhões” produzidos no edifício de exclusões criaram estrias resistentes. Lembranças difíceis de apagar. Expectativas difíceis de enterrar.

\section{Movimentos de massas e suas leis}

A escritora norte-americana Christopher Hayes lembra algo que nos interessa de perto:

"Existem poucas forças mais poderosas na política do que a mobilidade para baixo, a desapropriação daqueles antes privilegiados [...] a tarefa mais difícil que um ativista enfrenta quando organiza os pobres ou a classe trabalhadora é convencê-los de eles têm direito a algo melhor, que podem apresentar suas próprias reivindicações e que elas serão levadas a sério. A classe médiaalta da América não precisa de tal provocação." [Twilight of the Elites: America After Meritocracy]

Deveríamos pensar seriamente nessa "lei" da teoria dos movimentos sociais - para julgar sua pertinência, seus limites, as condições em que se aplica. E o que dela se deduz como orientação para quem quer mudar o mundo, não fazê-lo repetir sua trajetória. 
Na verdade, há várias "leis" nessa lei geral. Ou dois lados da lei. Uma delas se aplica aos indivíduos dos andares de cima da sociedade - a mobilização resultante da queda ou da ameaça percebida da queda. A outra ao lado de baixo: a organização e a mobilização desses segmentos exigem quase que uma revolução nos seus sentimentos, na sua percepção da "ordem das coisas".

Agora vejamos o Brasil recente e o que essas "leis" podem sugerir. Entre as classes médias, recentemente, vimos uma enorme mobilização de massas - ainda que fortemente inflada pela mídia orquestrante, claro. O objetivo desse movimento, é agora mais claro do que nunca: derrubar o governo de Dilma e tirar da pauta as políticas com ele identificadas. Essas classes médias tiveram perdas nesses 13 anos? Aqui e ali, esta ou aquela parcela desse grupo talvez tenha tido estagnação. Perda? Sim, houve pelo menos uma, grande, para a escala de preferências desse grupo social: perdeu a distinção. Algo que não se mede em absolutos, mas em relativos, em posicionais. Como? Perdeu aquilo que a punha acima da ralé. Aos poucos, a tal massa cheirosa foi percebendo a vizinhança incômoda da plebe. Nos aeroportos - "isto aqui está parecendo a rodoviária". Nas universidades - "isto aqui não é entidade assistencial", diz o reitor da USP. Nos shopping centers, a praia de cimento e vidro reservada aos bons - "os mano e as mina resolveram dar um rolê nessa praia”.

A primeira lei, portanto, parece ter evidenciado seu vigor. Isso, porém, nos deveria fazer refletir sobre o que pode acontecer agora, em 2018. Uma outra perda, desta vez em absolutos, parece chegar às classes médias - com uma recessão deliberadamente aprofundada, um "enxugamento" de empregos e rendas, um "liberou geral" para planos de saúde, mensalidades escolares e outros bens e serviços relevantes para tal segmento. $\mathrm{O}$ que acontecerá com essa classe média? Para que lado vai pender? Juntar-se-á a demandas dos de baixo ou constituirá, como muitas vezes ocorreu, a massa de manobra de uma direita do ressentimento?

\section{A queda do tabu e a criação de referências}

E o segundo vetor da lei, aquele que diz respeito aos debaixo? A lei diz que é difícil convencê-lo de que têm direito a algo melhor e 
que pode conseguir esse algo melhor. Lula é um grande frasista e costuma utilizar imagens do futebol. Lembro-me de uma dessas, talvez menos conhecida e difundida. Ainda da época em que presidia o sindicato de São Bernardo. Salvo engano, foi na chamada campanha pela reposição salarial, antes, portanto, das grandes greves de 1978. A imagem era esta: a classe trabalhadora está precisando de uma vitória, assim como o Corinthians precisa ganhar um campeonato. O Corinthians, na época, atravessava uma fase terrível, a fase do chamado "tabu”, a fila de anos e anos sem ganhar qualquer título. A percepção de Lula era essa: o time entrava derrotado, começava as disputas já pensando "não é para nós". Tinha que romper essa barreira para dar um salto de qualidade. Assim ocorria com a classe trabalhadora - uma vitória, ainda que pequena, mas perceptível, ampliaria de tal modo sua confiança que a partir daí seria difícil segurá-la. "Que ninguém mais duvide da capacidade de luta da classe trabalhadora" foi o saldo maior que viu na greve de 1979, derrotada nas suas demandas de reajuste.

É isto o que podemos tirar da "lei" que Hayes enunciou. Mas podemos tirar mais, no contexto em que estamos. Vivemos um momento em que os andares de baixo de nossa sociedade - os trabalhadores sindicalizados do sudeste, mas também as massas mais desprovidas e abandonadas do nordeste e dos rincões - tiveram um gosto, um pequeno gosto de conquistas antes sequer visualizáveis. Não apenas o acesso ao avião e à universidade. Algo mais elementar. Comer três vezes ao dia, para milhões. Cisternas e "luz para todos", crédito, muitas e muitos gostinhos de uma vida antes inimaginável. Uma alteração no "padrão alimentar".

Uma vez um economista engomadinho do plano Collor respondeu com surpresa e arrogância à pergunta simples de um repórter: como o governo faria aplicar sua politica de congelamento e controle de preços e contratos no que diz respeito aos cheques pré-datados? A resposta: o plano nada estabelecia porque legalmente o cheque prédatado não existia. Não podia ser mais hilário e ao mesmo tempo tão exuberante a arrogância do sábio: aquilo que a lei não prevê não existe. O que, alias, é uma interpretação singular da lei: aquilo que a lei não proíbe, a realidade pode fazer existir sem que seja passível de pena. $\mathrm{O}$ cheque pré-datado não existe no terreno do engomadinho, mas existia no cotidiano da "plebe". Era assim (em grande parte ainda 
é) que se comprava, por exemplo, material de construção para construir ou reformar o barraco. Ora, nos últimos 13 anos, a conta em banco e o acesso a um talão foram coisas massificadas por uma política da Caixa Econômica Federal. Para horror de muita gente que pensa (enviezadamente) que a plebe é mais propícia ao endividamento e ao calote do que os "de bens".

Nesse mundo - em que algumas coisas deixaram de ser objetivos irreais e entraram na conta do viável e, até, do direito - é compreensível que a figura identificada com esses avanços seja venerada como o líder na conquista do campeonato. Abriu uma porta e por ai mais coisa pode passar. $\mathrm{Ou}$, mais importante: precisa passar. $\mathrm{O}$ tabu foi quebrado. $\mathrm{O}$ ídolo que marcou o gol é lembrado e venerado.

É esse o quadro que temos diante de nós. É apenas um quadro tosco, cheio de lacunas e incertezas. Exageros, detalhes mal desenhados. Não me iludo sobre a precisão dos traços. Apenas sugiro que pensemos nele como esboço. Se alguém quer mudar esse quadro de destruição que se criou no pós-golpe, é preciso que enfrente esses enigmas. 


\section{VI}

\section{A REFORMA TRABALHISTA NO BRASIL E O GOLPE DE 2016: UMA ABORDAGEM SÓCIO- JURÚDICA *}

Qoberto Oeloani

Como sabemos, os três princípios básicos da Constituição Federal de 1988 - e o que a distingue fortemente das cartas magnas anteriores - são os seguintes: 1) o compromisso com um Estado Democrático de Direito; 2) o compromisso com uma concepção humanística e social; 3) o compromisso com a concepção constitucional de direitos fundamentais da pessoa humana. Assim, a matriz constitucional de 1988 tem por escopo a concepção de Direito como instrumento de civilização e emancipação, ao invés da ultrapassada, mas renitente, concepção de Direito como mecanismo de segregação, exclusão e desigualdade entre grupos sociais e pessoas

A reforma trabalhista implementada no Brasil por meio da Lei n. 13.467, de 13 de julho de 2017, caracteriza-se pela tendência ao retorno à antiga concepção do ordenamento jurídico como mecanismo de exclusão, segregação social e legalização da desigualdade social. Seu caráter regressivo, destoa da compreensão do Direito como instrumento de civilização, presente na Carta Magna de 1988. Só para que se tenha uma ideia, pelo novo diploma legal, o beneficiário da justiça gratuita responde, sim, pelo pagamento dos honorários periciais, caso sucumbente no objeto da perícia (art.790-B, caput, da CLT, conforme Lei n. 13.467/2017). Isto é, todo o sábio sistema construído pelo Poder Judiciário e pelo Poder Legislativo no sentido de a União ser responsabilizada por esse encargo - responsabilidade limitada, é claro, a valores razoáveis -, foi desconsiderado pela nova legislação, como nos ensinam os grandes juristas Maurício Godinho Delgado e Gabriela Neves Delgado, na obra "A reforma trabalhista no Brasil

*DOI - 10.29388/978-85-53111-28-2-()-f.89-100 
com os comentários à Lei n. 13.467/2017 (DELGADO \& DELGADO, 2017).

O jornal Folha de São Paulo, em seu Caderno Mercado, no dia 13 de dezembro de 2017, noticiou um fato difícil de se crer, mas, infelizmente, verídico: uma bancária do ITAÚ foi condenada a pagar $\mathrm{R} \$ 67,5$ mil ao banco para cobrir os custos com advogados, depois de sucumbir a uma ação ajuizada em 11 de julho de 2017. A decisão do magistrado, de uma Vara do Trabalho, de importante município do Estado do Rio de Janeiro, só foi publicada no final de novembro, e foi fundamentada nas novas regras da Lei 13.467, denominada Reforma Trabalhista. Ou melhor, a ação foi ajuizada em 11 de julho, mas a decisão do juiz, publicada no final de novembro, usou como base as novas regras da Reforma Trabalhista que entraram em vigor em 11 de novembro!

A trabalhadora, que tinha a função de gerência em uma agência do referido município, demandava $\mathbf{R} \$ 40$ mil por direitos que não foram honrados pelo banco. O próprio magistrado considerou este valor escasso e majorou a petição para $\mathbf{R} \$ 500$ mil. Apenas uma parte das solicitações foi outorgada a favor da ex-bancária, como os $15 \mathrm{mi}-$ nutos de intervalo entre a jornada habitual e as horas extras. Todavia, a reclamante foi sucumbente nos demais pedidos, isto é, o magistrado ponderou que suas solicitações não procediam, como intervalo de digitador, abono de caixa, acúmulo de função, horas extras, dano moral por assédio moral e danos materiais. Ademais, a bancária também não teria direito ao benefício da Justiça gratuita.

Em função da "vitória" da trabalhadora em relação ao intervalo (estipulado em $\mathbf{R} \$ 50$ mil) o referido banco foi condenado a pagar $\mathrm{R} \$$ 7,5 mil para as despesas advocatícias. No entanto, a ex-bancária, que sucumbiu no que concerne aos outros quesitos, que somaram $\mathbf{R} \$$ 450 mil, terá de desembolsar $\mathbf{R} \$ 67,5$ mil. Como se não bastasse, a este valor, o magistrado ainda acresceu $\mathrm{R} \$ 1$ mil às custas processuais a serem saldadas pela trabalhadora. (HELOANI \& BARRETO, 2018)

Outros princípios da Carta Magna de 1988 foram deliberadamente desrespeitados pela Reforma "Modernizadora", o que nos leva a crer que a continuar essa tendência corremos o risco de termos o conceito de emprego (que é espécie) muito próximo ao conceito de 
trabalho (que é gênero), ou seja, de termos de aceitar empregos sem direitos. Como poderá ser notado, em síntese, o processo de modernização das relações de trabalho consiste na implantação de um conjunto de medidas que tem por escopo agenciar:

"1.a substituição da lei pelo contrato; 2. a adoção de uma legislação mínima, residual, a ser complementada pela negociação / contratação; 3. a criação de diferentes tipos de contrato, distintos do padrão de assalariamento clássico representado pelo contrato por tempo indeterminado; 4. a substituição de direitos universais por direitos diferenciados; 5. a descentralização da negociação coletiva, se possível ao âmbito da empresa; 6 . a substituição da intervenção estatal na resolução dos conflitos trabalhistas pela auto composição das partes. Não por acaso, desregulamentação e/ou flexibilização das relações de trabalho se tornam palavras de ordem dessa reforma supostamente modernizadora.” (TEIXEIRA et ali, 2017, p. 41)

Às vezes, o descaso em relação a certos princípios humanísticos, acarretam situações burlescas, para se dizer o mínimo. Pelas novas normas da Lei 13467/2017, denominada Reforma Trabalhista, o trabalhador intermitente que aufere menos de um salário mínimo terá de integrar a contribuição ao INSS. Expliquemo-nos. No dia 27 de novembro de 2017 a Receita Federal noticiou as regras para o recolhimento da contribuição previdenciária dos trabalhadores intermitentes cujo ganho mensal estiver aquém do salário mínimo. Situação “original” no Brasil, o trabalhador poderá ter de pagar a diferença entre a contribuição incidente sobre o contracheque e o mínimo demandado pela Previdência Social. Isto porque nesta forma contratual, intermitente, o trabalhador opera somente quando é demandado. Assim, o seu salário oscila consoante o número de horas ou dias que efetivamente trabalhou. Pela legislação atual, faz-se necessário ganhar, no mínimo, valor proporcional ao mínimo por hora, isto é, $\mathrm{R} \$ 4,26$, ou dia trabalhado, $\mathrm{R} \$ 31$, 23. Como a base de cálculo é o contracheque, se o trabalhador tiver salário inferir ao mínimo, terá recolhimento aquém do exigido pelo INSS. Assim, como reza a legislação, o trabalhador poderá recolher a diferença entre a contribuição calculada sobre o contracheque e o mínimo demandado pelo INSS. Se por alguma razão negar-se a isso, não terá direito de usufruir os benefícios (como licença médica, por exemplo) e não terá acesso à aposentado- 
ria.

Como nos ensina Marilane Teixeira et ali, 2017, no ótimo texto Contribuição crítica à reforma trabalhista, a Consolidação das Leis do Trabalho (CLT) abraçou um sistema misto que combina um modelo legislado às negociações coletivas, válidas desde que respeitadas as regras de proteção ao trabalho. Faz-se mister pontuar que a legislação foi, paulatinamente, moldada aos diversos contextos políticos do Brasil. Essa adaptação foi efetuada desde a década de 1940 até a Constituição Federal de 1988, denominada por muitos juristas como Constituição Cidadã. Desde modo, esse texto legal não pode ser visto como um projeto "ultrapassado" ou tampouco "ilegítimo". Tal como sucedeu com outros dispositivos jurídicos, como, por exemplo, o Código Civil, a Consolidação das Leis do Trabalho foi modificada gradualmente, mediante a utilização de emendas constitucionais, medidas provisórias, decretos e demais leis. Até o ano de 2016, ocorreram 233 alterações, $75 \%$ delas calharam pelo caminho legislativo. Apenas na ditadura militar - como não poderia ser diferente - houve maior quantidade de decretos emanados do Poder Executivo.

A par de todas essas restrições que destoam dos princípios filosóficos e jurídicos da Constituição Federal de 1988, nos deteremos aqui, neste livro, aquele que mais nos interessa, ou seja, ao denominado dano extrapatrimonial. A Lei n. 13.467, de 13 de julho de 2017 procurou regular aspectos do contrato de trabalho anteriormente sem normatização direta pela legislação federal. Nesse sentido, forçoso reconhecer sua positividade. Contudo, o espírito que predominou no preenchimento dessas lacunas está longe de parear princípios humanistas e coerentes com um conceito de Estado Previdência protetor. Explicamo-nos:

Os temas dos danos morais, inclusive estético e material ainda não haviam sido normatizados pelo texto da Consolidação das Leis do Trabalho (CLT). Essa ausência era suprida, sem grandes problemas, com a utilização de normas civilistas e constitucionais para os casos de danos congêneres na esfera do mundo do trabalho. A Lei da Reforma Trabalhista optou, porém, elaborar específica regulação sobre o tema, mediante acréscimo de um novo segmento na CLT, o Título II-A- Do Dano Extrapatrimonial -, constituído pelos arts. 223-A até 223-G (DELGADO\&DELGADO, 2017). 
Assim, a Lei Da Reforma Trabalhista mediante acréscimo de um novo dispositivo legal na Consolidação das Leis Trabalhistas, o Título II-A- Do Dano Extrapatrimonial, realizou uma polêmica alteração na CLT, em vigor desde 11 de novembro de 2017. Vejamos o novo texto:

"TÍTULO II-A

\section{DO DANO EXTRAPATRIMONIAL}

Art. 223-A. Aplicam-se à reparação de danos de natureza extrapatrimonial decorrentes da relação de trabalho apenas os dispositivos deste Título. (Grifo nosso)

Art. 223-B. Causa dano de natureza extrapatrimonial a ação ou omissão que ofenda a esfera moral ou existencial da pessoa física ou jurídica, as quais são as titulares exclusivas do direito à reparação. (Grifo nosso)

Art. 223-C. A honra, a imagem, a intimidade, a liberdade de ação, a autoestima, a sexualidade, a saúde, o lazer e a integridade física são os bens juridicamente tutelados inerentes à pessoa física.

Art. 223-D. A imagem, a marca, o nome, o segredo empresarial e o sigilo da correspondência são bens juridicamente tutelados inerentes à pessoa jurídica. (Grifo nosso)

Art. 223-E. São responsáveis pelo dano extrapatrimonial todos os que tenham colaborado para a ofensa ao bem jurídico tutelado, na proporção da ação ou da omissão.

Art. 223-F. A reparação por danos extrapatrimoniais pode ser pedida cumulativamente com a indenização por danos materiais decorrentes do mesmo ato lesivo. (Grifo nosso)

\& $1^{\circ}$ Se houver cumulação de pedidos, o juízo, ao proferir a decisão, discriminará os valores das indenizações a título de danos patrimoniais e das reparações por danos de natureza extrapatrimonial.

\& $2^{\circ}$ A composição das perdas e danos, assim compreendidos os lucros cessantes e os danos emergentes, não interfere na avaliação dos danos extrapatrimoniais.

Art. 223-G. Ao apreciar o pedido, o juízo considerará: 
I - a natureza do bem jurídico tutelado;

II - a intensidade do sofrimento ou da humilhação;

III - a possibilidade de superação física ou psicológica;

IV - os reflexos pessoais e sociais da ação ou da omissão;

V - a extensão e a duração dos efeitos da ofensa;

VI - as condições em que ocorreu a ofensa ou o prejuízo moral;

VII _ o grau de dolo ou culpa;

VIII - a ocorrência de retratação espontânea;

IX - o esforço efetivo para minimizara a ofensa;

X - o perdão, tácito ou expresso;

XI - a situação social e econômica das partes envolvidas;

XII - o grau de publicidade da ofensa.

\& 1ํ Se julgar procedente o pedido, o juízo fixará a indenização a ser paga, a cada um dos ofendidos, em um dos seguintes parâmetros, vedada a acumulação:

I - ofensa de natureza leve, até três vezes o último salário contratual do ofendido;

II - ofensa de natureza média, até cinco vezes o último salário contratual do ofendido;

III - ofensa de natureza grave, até vinte vezes o último salário contratual do ofendido;

IV -ofensa de natureza gravíssima, até cinquenta vezes o último salário contratual do ofendido.

\& $2^{\circ}$ Se o ofendido for pessoa jurídica, a indenização será fixada com observância dos mesmos parâmetros estabelecidos no $\& 1^{\circ}$ deste artigo, mas em relação ao salário contratual do ofensor.

\& $3^{\circ}$ Na reincidência entre partes idênticas, o juízo poderá elevar ao dobro o valor da indenização. " (HELOANI \& BARRETO, 2018) 
Consoante a nova legislação, não faz mais sentido falar em dano moral, dano estético e conceitos similares. Agora, uma única categoria se apresenta: a dos danos extrapatrimoniais, concernentes às empresas e aos trabalhadores, que se tornam análogos e parecidos em detrimento da pessoa humana e dos princípios constitucionais protetores da Carta Magna de 1988.

Ademais, sobre a tarifação da indenização por dano moral, o art. 223-G, \& 1 $1^{\circ}$, incisos I até IV, estabelece tarifação da indenização por dano extrapatrimonial, desconsiderando que a Carta constitucional de 1988 não admite o critério de tarifação da indenização por dano moral em seu art. $5^{-}$, V, ao mencionar, insistentemente, o princípio de proporcionalidade.

Infelizmente, faz-se mister admitir que pela interpretação literal da Lei da Reforma Trabalhista, sem as adequações interpretativas (Hermenêutica Jurídica) teremos que:

a) admitir que a ordem jurídica diferencie as afrontas morais em função da renda das pessoas envolvidas (art. 223-G, \& 1º, I, II, III e IV);

b) admitir que a indenização devida por uma pessoa a uma organização (o contrário é idêntico) se avalia pelos mesmos critérios econômicos do cálculo de uma indenização devida por uma empresa (independentemente de seu porte e influência) a uma pessoa humana (art. 223-G, \& $2^{\circ}$ );

c) admitir que a reincidência cometida por certa empresa somente se computa se for praticada contra a mesma pessoa física (\& $3^{\circ}$ do art. 223-G). (DELGADO\&DELGADO, 2017)

Em termos práticos, o novo art. 223-A ao G cria faixa de valores para a indenização por danos morais, consoante o salário do trabalhador e também admite a indenização da pessoa jurídica, isto é, da empresa. Assim, empregados e organizações poderão reclamar dano moral na Justiça do Trabalho

Desta forma, no que concerne às indenizações cabíveis, com base na Lei n. 13.467, de 13/7/2017 e nova Medida Provisória n. 808/2017, temos quatro tipos de ofensas - de acordo com o entendimento do magistrado, a saber: 1) natureza leve; 2) media; 3) grave; 4) gravíssima. Observemos novamente a nova legislação laboral: 
"\& 1ำ Se julgar procedente o pedido, o juízo fixará a indenização a ser paga, a cada um dos ofendidos, em um dos seguintes parâmetros, vedada a acumulação:

I - ofensa de natureza leve, até três vezes o último salário contratual do ofendido;

II - ofensa de natureza média, até cinco vezes o último salário contratual do ofendido;

III - ofensa de natureza grave, até vinte vezes o último salário contratual do ofendido;

IV - ofensa de natureza gravíssima, até cinquenta vezes o último salário contratual do ofendido.

\& $2^{\circ}$ Se o ofendido for pessoa jurídica, a indenização será fixada com observância dos mesmos parâmetros estabelecidos no $\& 1^{\circ}$ deste artigo, mas em relação ao salário contratual do ofensor." (Grifos nossos)

Em caso de acidente, por exemplo, a indenização a ser paga passa a ser calculada em função do valor do salário do trabalhador. Aquele que tiver salário maior terá direito a uma indenização mais expressiva. Aquele que tiver um salário mais modesto deverá contentarse com uma indenização muitas vezes irrisória. Assim, sob a justificativa da necessidade de "requisitos objetivos para a configuração do dano e critérios de cálculo" o legislador viola o princípio de isonomia de tratamento, desdenha a capacidade econômica do agressor e do lesado e determina indenizações desiguais, fundamentadas na posição e remuneração dos envolvidos e não na gravidade do dano. No que se relaciona às custas processuais, essas deverão ser pagas pela parte perdedora da ação, mesmo se o trabalhador for de baixa renda. Os que advogam tal preceito alegam que "a norma tenta coibir processos trabalhistas infundados".

Isto nos leva a concluir que em uma mesma organização um engenheiro e um trabalhador menos graduado que venham a sofrer ofensas do mesmo teor por parte de um superior hierárquico, por exemplo, terão, se ajuizarem ação contra a empresa e ganharem, indenizações diferentes, embora a ofensa seja exatamente a mesma. O engenheiro ganhará uma reparação monetariamente maior que a do trabalhador menos graduado, pois a indenização estará vinculada ao últi- 
mo salário do ofendido. Sem dúvida, a nosso ver, a Reforma Trabalhista que alterou a CLT monetariza o dano, o sofrimento humano e altera o próprio conceito de Dignidade.

Infelizmente, o projeto neoliberal de Estado não atinge somente o Brasil. Na terra do Iluminismo, a França, em 2016, também se estabeleceu limite no que concerne ao pagamento de indenizações. Do mesmo modo se restringiu o sagrado direito de desconectar-se (que consiste em admitir que "colaboradores" de uma determinada organização - quando acordados - desdenhem telefonemas, e-mails, mensagens via celular etc., da empresa na qual trabalham durante a folga) (HELOANI, 2018; HELOANI \& BARRETO).

A Reforma Trabalhista na CLT institui o conceito de dano extrapatrimonial que abraça situações diversas que envolvem o dano moral decorrente de assédio, por exemplo. Esse tipo de dano tem como causa "a ação ou omissão que ofenda a esfera moral ou existencial da pessoa física ou jurídica”. A responsabilidade pelo dano extrapatrimonial é de todos que por alguma razão tenham, de alguma maneira, colaborado para ofensa ao bem jurídico tutelado. Mas também, o mesmo conceito, se alargado no que concerne ao seu entendimento, poderá considerar a penalização de ações coletivas ou individuais dos trabalhadores que, por ventura, ocasionem danos à marca (imagem da empresa). Vale lembrar que o pedido de reparação pode ser cumulativo com o pedido de indenização por danos materiais decorrentes do mesmo ato lesivo. (HELOANI \& BARRETO, 2018)

No que concerne ao ônus da prova, a Lei n. 13.467/2017 modificou toda a redação do artigo 818 da Consolidação das Leis do Trabalho, que era assim: "Art. 818 A prova das alegações incumbe à parte que as fizer". No novo dispositivo jurídico, incorporou-se a sistemática lançada no artigo 373 do Novo Código de Processo Civil, de 2015, que, a propósito, também versa sobre a distribuição do ônus da prova no processo judicial. O novo texto legal está presente no caput do artigo 818 (nova redação) e nos incisos I e II, além dos \&\& $1^{\circ}, 2^{\circ}$ e $3^{\circ}$, da referida cláusula da Consolidação das Leis do Trabalho. Vejamos a nova redação:

“Art. 818. O ônus da prova incumbe:

I - ao reclamante, quanto ao fato constitutivo de seu direito; 
II -ao reclamado, quanto à existência de fato impeditivo, modificativo ou extintivo do direito do reclamente.

\& $1^{\underline{o}}$ Nos casos previstos em lei ou diante de peculiaridades da causa relacionadas à impossibilidade ou à excessiva dificuldade de cumprir o encargo nos termos deste artigo ou à maior facilidade de obtenção da prova do fato contrário, poderá o juízo atribuir o ônus da prova de modo diverso, desde que o faça por decisão fundamentada, caso em que deverá dar à parte a oportunidade de se desincumbir do ônus que lhe foi atribuído.

\& $2^{\circ}$ A decisão referida no \& $1^{\circ}$ deste artigo deverá ser proferida antes da abertura da instrução e, a requerimento da parte, implicará o adiamento da audiência e possibilitará provar os fatos por qualquer meio em direito admitido.

$\& 3^{\circ} A$ decisão referida no \& $1^{o}$ deste artigo não pode gerar situação em que a desincumbência do encargo pela parte seja impossível ou excessivamente difícil."

Mauricio Godinho Delgado e Gabriela Neves Delgado, no excelente livro já citado, "A reforma trabalhista no Brasil com os comentários à Lei n. 13.467/2017 (Delgado\&Delgado, 2017) nos lembram que a jurisprudência trabalhista, desde o início da década de 1990, já incorporava o critério jurídico da inversão do ônus da prova explicitado no Código de Defesa do Consumidor (artigo $6^{\circ}$, inciso VIII). O Novo Código de Processo Civil, de 2015, em seu artigo 373, $\& \& 1^{\circ}$ e $2^{\circ}$, acatou esse critério. Seguindo essa tendência e diretriz, o mesmo fez o texto dos novos $\& \& 1^{\circ}, 2^{\circ}$ e $3^{\circ}$ do artigo 818 da CLT.

Assim sendo, em resumo, no que concerne ao ônus da prova, em princípio, cabe ao reclamante provar o fato constitutivo de seu direito e ao reclamado, a existência de fato impeditivo. A inspiração está no art. 373 do Novo Código de Processo Civil. Este artigo prevê a aplicação da teoria dinâmica do ônus da prova no processo laboral, ou seja, o juiz poderá determinar a inversão do ônus da prova contanto que tal fato não seja deveras difícil ou mesmo impossível de ser feito. Se me permitem a ironia respeitosa, esse dispositivo jurídico, no caso brasileiro do Golpe de 2016, exigirá dos títeres e responsáveis por ele invejável condão de prestidigitação! 


\section{REFERÊNCIAS}

BRASIL. Superior Tribunal de Justiça. Súmula nº 37. . Superior Tribunal de Justiça. Súmula n²27.

BARROS, Alice Monteiro de. Proteção à intimidade do empregado. São Paulo: LTr, 1997.

DELGADO, Mauricio Godinho \& DELGADO, Gabriela Neves. A reforma trabalhista no Brasil: com os comentários à Lei n. 13.467/2017.São Paulo: LTR, 2017.

FREITAS, Ester; HELOANI, Roberto; BARRETO, Margarida. Assédio moral no trabalho. São Paulo: Editora Cengage Learning, 2008.

HELOANI, Roberto. Modelos de gestão e educação: gerencialismo e subjetividade. São Paulo, Editora CORTEZ, 2018.

HELOANI, Roberto \& BARRETO, Margarida. Assédio moral: gestão por humilhação. Curitiba, Editora JURUA, 2018.

LOPES, Mauricio Antonio Ribeiro. Código civil. São Paulo: Ed. Revista dos Tribunais, 2000.

NASCIMENTO, Amauri Mascaro. Curso de direito do trabalho. São Paulo: Saraiva, 2006.

ORGANIZAÇÃO INTERNACIONAL DO TRABALHO (OIT). Chappell D, Di Martinno, V. Violence at Work. Geneve: International Labour Office, 2006.

SÃO PAULO. Controladoria Geral do Município de São Paulo. Corregedoria Geral, Divisão de Promoção da Ética e Procuradoria Geral do Município. Assédio Sexual na Administração Municipal. Como Denunciar? São Paulo: Prefeitura de São Paulo, novembro de 2017. TEIXEIRA, Marilane et al. (Coordenadores). Contribuição crítica à reforma trabalhista. Campinas, SP: UNICAMP/IE/CESIT, 2017.

VADE MECUM SARAIVA. 14.edição atualizada e ampliada. São Paulo: Saraiva, 2018. 



\title{
VII
}

\section{MERCANTILIZAÇÃO DA EDUCAÇÃO, A REFORMA TRABALHISTA E OS PROFESSORES: O QUE VEM POR AÍ?*}

\author{
Evaldo 叉iolli
}

Em Março de 2016 se encerra o ciclo da Nova República que tinha a constituição de 1988 como um de seus pilares. Entramos num contexto muito parecido com a Ditadura Civil-Militar (1964-1985) com uma tendência ao recrudescimento das liberdades democráticas e o avanço das forças liberais conservadores e do neoliberalismo radical ditado pelas forças do mercado, do grande capital, principalmente o financeiro, e do rentismo. Essa agenda dos ajustes envolveu primeiramente a votação da PEC 95/2016, seguida pela reforma trabalhista e a reforma da previdência, ainda não votada. Essas medidas se somam às medidas fiscais como as Desonerações Fiscais e a PEC 87/2015 que trata da Desvinculação das Receitas da União (DRU).

A DRU constitui-se, portanto, como um reforço substancial às medidas de ajuste para cumprimento das metas fiscais e garantia ao pagamento da dívida, que somada à PEC 95/2017, produzirão efeitos diretos aos investimentos à Educação, tensionando para medidas de privatização, parcerias público-privada e terceirização. Isso está em total conformidade com os princípios defendidos no "Ponte para o futuro" que defende medidas desse tipo, combinada com a proposição das desvinculações das verbas constitucionais, no caso, a obrigatoriedade de aplicação de $18 \%$ dos recursos arrecadados de impostos à educação, conforme o artigo 212 da Constituição Federal.

Especificamente sobre aos possíveis efeitos da EC 95/2017 na educação, um estudo feito pelo Fineduca apontou que com essa medida, que congela os gastos por 20 anos, o percentual de $18 \%$ estaria comprometido, assim como, as metas do novo PNE (2014-2024). O

"DOI - 10.29388/978-85-53111-28-2-0-f.101-112 
estudo foi elaborado pelo Professor José Marcelino Rezende Pinto e aponta que "considerando-se um crescimento da receita real de $3 \%$ ao ano, após 5 anos a vinculação já estaria em 16\%; após 10 anos, em $13,8 \%$ e após 20 anos chegaria a 10,3\%, ou seja, uma redução de $43 \%$ no índice”. (FINEDUCA, 2014)

A reversão dessa vinculação de recursos, com a PEC 95/2017, pode ser comparada à quebra da proposição de verbas vinculadas para a Educação, que ocorreu em períodos autoritários como do Estado Novo (1937-1945) e da Ditadura Civil-Militar (1964-1985), que retrocederam avanços nesse sentido. Considerando que em todas as constituições até 1934 não previam vinculações obrigatórias para aplicação na Educação.

O corte dos gastos, instituídos com a PEC 95/2017 e a DRU, combinado com os critérios da Lei Complementar n⿳o 101 (LC101), ou Lei de Responsabilidade Fiscal (LRF), tensionarão para que medidas em favor da transferência de responsabilidades do Estado para o setor privado se intensifiquem. A LRF, desde sua implantação, se constituiu como um mecanismo impeditivo à contratação de profissionais na área da educação, estabelecendo uma regulação draconiana a gestão dos sistemas educacionais nos municípios e nos estados que fomentou a contratação precária de professores e a terceirização massiva. Na educação infantil já é uma realidade a presença de operadoras filantrópicas ou do mercado atuando em parceria com os municípios. Nesses âmbitos, como no caso do Projeto Nave-Mãe em Campinas a remuneração do pessoal se faz pela Consolidação das Leis do Trabalho, podendo chegar a $50 \%$ do que o pessoal estatutário percebe além de uma jornada de trabalho mais extensa. (PELLISSONA, 2016)

No setor público, o não cumprimento da Lei Nacional do Piso do Magistério, Lei n. 11.738 de 16 de julho de 2008 (Brasil, 2008) afeta milhares de profissionais que trabalham em na maior parte dos Estados e Municípios, conforme informa a Confederação Nacional dos Trabalhadores na Educação - CNTE ${ }^{1}$. A Lei é cumprida em apenas 9 estados brasileiros. Em 8 estados, a lei não é cumprida na sua integralidade, principalmente nos requisitos referentes à hora-atividade, a qual deve representar, minimamente, $1 / 3$ da jornada de trabalho do

${ }^{1} \mathrm{O}$ valor fixado para 2018 é de $\mathrm{R} \$ 2.455,35$ para 40 horas semanais. 
professor. Nos municípios o quadro ainda é mais grave. Dentre 5640 municípios pesquisados, 50\% (2822), não possuem planos de carreira, apenas 44,9\% (2533) cumprem o valor do salário determinado pela Lei e, apenas $38,45 \%$ cumprem a jornada referente à hora-atividade. (CNTE,2018)

Para o conjunto dos trabalhadores da educação, o quadro de precarização e de instabilidade pode vir a agravar se as parcerias com o setor privado forem intensificadas e ampliadas, conforme estamos prevendo. Lembrando que para a contratação de pessoal nas organizações privadas que atuam na educação, valem as regras previstas na CLT. Chamamos atenção para isso, destacando que devemos acender um sinal de alerta, já que os exemplos advindos do privado, não são positivos. Temos que ficar atentos para as novas formas de contratação e de normatização docente que poderão emergir do setor privado a partir da reforma trabalhista implementada no Brasil por meio da Lei n. 13.467, de 13 de julho de 2017. Essa Lei expressa-se como a mais perversa dentre todas as reformas, por estar em consonância com uma concepção do ordenamento jurídico como mecanismo de exclusão, segregação social e legalização da desigualdade social. Sem dúvida, trará inúmeros prejuizos para o conjunto dos trabalhadores do país. Conforme destaca Heloani (2018), o caráter regressivo da Reforma, destoa da compreensão do Direito como instrumento de civilização, presente na Carta Magna de 1988.

Mas a verdade é que os atuais ocupantes do poder não ficam "em cima do muro" e querem liberar as empresas, desvinculando-as das suas responsabilidades sociais que envolvem as conquistas dos trabalhadores e de seus direitos para impor uma agenda do regresso e da total submissão da economia ao "despotismo do capital".

A combinação de fatores acima descrita, atrelada ao falacioso discurso da falta de recursos, estão sendo utilizados para justificar a aceleração de reformas educativas voltadas para o mercado e aos homens de negócio. No ensino superior os estímulos são expressivos e envolvem o acesso ao crédito e bolsas, dentro do programa FIES e do PROUNI. Na educação básica, grandes grupos privados de capital aberto se movimentam, focalizando a educação básica para atender os novos requisitos fixados pela BNCC e a Reforma do Ensino Médio. São ações de reforma, na educação básica decorrente da agenda do se- 
tor empresarial, ou melhor, dos Reformadores Empresariais influem mais diretamente nas decisões dentro do MEC. Esses atores advogam em favor da eficiência e da eficácia empresarial, da gestão inspirada no mercado e na política centrada em avalições e resultados quantitativos. As possibilidades de negócios se ampliam, não mais apenas para a oferta de vagas no ensino superior, mas também, na educação básica e para uma gama mais ampla de serviços que envolvem consultorias, produção e venda de materiais didáticos, plataformas de EaD entre outros. Abre-se espaço para que sejam ampliadas as formas de acesso aos fundos públicos da educação.

As parcerias-público-privado, a direta privatização e a terceirização dos serviços educacionais poderão vir a agravar o quadro de precarização do trabalho dos professores no setor público, além de intensificar a fragilização dos direitos ${ }^{2}$. Poderão ser introduzidas novas formas de contratação para além das que foram previstas na EC 19 de 1998, tais como, estatutários e celetistas. Sobre isso, devemos lançar nosso olhar para as formas de contratação e vínculo que ocorrem no setor privado da educação, principalmente no ensino superior. Pois, é nesse nível de ensino que novas situações contratuais tendem a se tornar paradigmáticas, inclusive para as organizações e empresas que atuam, ou deverão atuar, junto ao setor público.

A expressiva expansão do setor privado com um significativo aumento das matrículas nas IES, provocadas pelos fatores condicionantes governamentais como o Fies (Lei 10260/2001 e reformulação Lei 11552/2007) e o PROUNI (Lei 11096/2005) e, também, dos fatores condicionantes de mercado decorrente da flexibilização da legislação em favor do mercado, como o Decreto $n^{\circ}$ 2.306, de 10 de agosto de 1997, não produziram um quadro de maior estabilidade no emprego para os docentes que fosse proporcional ao crescimento do setor. $\mathrm{Na}$ verdade, o quadro permitiu que o mercado se expandisse com grandes operações de fusões e aquisições do setor, criando conglomerados de capital aberto muito lucrativos. Esse é o mesmo movimento - de aquisição e fusão - que se anuncia na educação básica a partir do ingresso de grandes grupos econômicos no setor. E para satisfazer as

\footnotetext{
${ }^{2}$ Conforme aponta um levantamento feito pela CNTE (2017), baseado em dados do INEP, a contratação temporária vem crescendo. O Estado do Mato Grosso, mantém 60\% de seus professores como temporários, seguido por Santa Catarina, 57\%, Mato Grosso do Sul, 50\%, Minas Gerais 48\%, Pernambuco 44\% e São Paulo, $34 \%$.
} 
expectativas de lucro de seus investidores, esses grupos de capital aberto que já empregam esquemas de gestão voltados para a hiperexploração do trabalho docente começam, agora, a tensionar para que os critérios da reforma trabalhista sejam aplicados.

Durante as negociações para renovação da Convenção Coletiva, cuja data-base foi $1^{\circ}$ de março de 2018, os professores das instituições privadas de ensino, de todos os níveis, apontaram as tentativas das entidades patronais efetuarem a aplicação da reforma trabalhista à convenção coletiva de trabalho, por meio de propostas como : fim da isonomia salarial, que permitiria a contratação de novos professores por salários inferiores aos já pagos pelas instituições, a instituição do banco de horas, que colocaria fim ao pagamento de horas-extras, a legalização de contratação por meio de pessoa jurídica ou MEI, além da contratação por meio de terceirização e de trabalho intermitente. Propuseram ainda a redução do recesso, o parcelamento das férias coletivas, a remuneração dos docentes pelas horas trabalhadas em sala de aula, sem remunerar as "horas-atividade", ou melhor, o trabalho extraclasse; que equivale a implantação do trabalho intermitente com agrupamento da carga horária de uma determinada disciplina, rompendo com a garantia semestral de salários e legalizando a terceirização; ou seja, retirada de benefícios e desconstrução dos direitos coletivos por meio da negociação individualizada por escola com quebra das convenções coletivas. Ao todo, os patrões propuseram a supressão ou modificação em mais de 20 cláusulas que regulamentam o trabalho dos professores da educação privada, abrangendo os que trabalham em organizações e empresas prestadoras de serviços para o Estado.

No quesito precarização as IES privadas ficam na liderança dada a proliferação, nesse setor, de diferentes modalidades de curso, tais como: presencial; semipresencial e à distância. Sem considerar que na modalidade presencial, hoje é permitido que parte da carga horária, em torno de $25 \%$ seja oferecida em EaD. Nessas modalidades surgem outras nomenclaturas para designar esse trabalho e burlar as normas negociadas na Convenção Coletiva de Trabalho.

Em outras palavras: as denominações que antes serviam para situar os professores na carreira (adjunto e titular, por exemplo), hoje servem para fragmentá-los e para romper com uma noção - já frágil - de categoria, uma vez que para dar vazão às formas 
rebaixadas de contratação, as IES adotam nomenclaturas que excluem a palavra professor - trata-se antes do Tutor (de níveis I, II e III), monitor, instrutor, produtor de conteúdos -, configurando-se mais um instrumento de enfraquecimento dos sindicatos, pois com a criação de novas designações para o trabalho docentes, muitos professores acabam ficando órfãos de representação. (PIOLLI e SOUSA, 2017, p. 148)

Na direção do que estamos apontando vale destacar que muitos grandes grupos privados estão de olho nas novas possibilidades de negócio na Educação Básica em função da instituição da Base Nacional Comum Curricular (BNCC), mas sobretudo, pelo potencial que a Reforma do Ensino Médio oferece. Pelo que estamos prevendo, isso ocorrerá muito em função da expansão da carga horária das atuais 800 horas anuais ( 4 horas diárias) para 1 mil (5 horas diárias) em um prazo máximo de 5 anos e pela oferta das terminalidades, principalmente para a Formação Profissional. Nesse quadro, a maior flexibilização da EaD tende a aparecer com força. Para isso basta considerarmos o dado da realidade, pois dentro de um total de 5770 municípios brasileiros, apenas 53\% (2967) oferecem o Ensino Médio regular ou profissionalizante e mais, desse total, 41,9\% das escolas do País trabalham em turno triplo (INEP, 2016). A pergunta que fica é a seguinte: como se dará a oferta dos "itinerários formativos”, em termos de opções aos alunos? Como será feita a ampliação da carga horária?

A que se considerar ainda que inserção legislativa disposta no artigo 611-A da CLT que sobrepõe o negociado sobre o legislado, fere o artigo $7^{\circ}$ da Constituição Federal que protege os direitos dos trabalhadores urbanos e rurais, além de outros, assegurando que a possibilidade de mudanças na legislação de proteção ao trabalho desde que visem a melhorias vedando qualquer tipo de retrocesso social. A mudança no artigo, será indutora da fragilização das convenções coletivas a da substituição desse mecanismo por acordos coletivos entre patrões e empregados, por empresa. Para os defensores da reforma, isso poderá trazer maiores vantagens para os trabalhadores, no entanto, entendemos que tal mudança pode vir a se fixar como um mecanismo para retirada dos direitos.

A Reforma ainda fragiliza as organizações sindicais pela alteração do artigo 545 da CLT, relativo às contribuições compulsórias des- 
tacando que o recolhimento deve ser "devidamente autorizado" pelos trabalhadores. Como segue:

Art. 545. Os empregadores ficam obrigados a descontar da folha de pagamento dos seus empregados, desde que por eles devidamente autorizados, as contribuições devidas ao sindicato, quando por este notificados. (Redação dada pela Lei no ${ }^{\circ}$ 13.467, de 2017)

A reforma trabalhista modifica profundamente a fonte de recursos dos sindicatos dos trabalhadores ao suprimir a obrigatoriedade do imposto sindical, tornando-a facultativa, ou melhor, se o trabalhador desejar pagá-lo deve autorizar expressamente através de carta declaração para o empregador autorizando o desconto em folha. Tratase de uma mudança significativa em relação ao texto anterior, que não previa essa autorização dos empregados, tornando facultativa uma contribuição que antes era compulsória.

Sabemos que as contribuições compulsórias e o atrelamento da estrutura sindical ao estado no Brasil, se constituiu como uma "fábrica de pelegos", no entanto, há que se considerar que os sindicatos de trabalhadores são uma das poucas organizações existentes voltadas para a defesa e proteção dos direitos dos trabalhadores. Devemos considerar que entre pelegos e sindicatos de carimbo burocratizados e despolitizados, existem valorosas entidades de luta que serão atingidas diretamente por essa medida fragilizando sua organização. Nesse sentido, a fragilização ou mesmo o desmonte do sistema sindical brasileiro, consolida os propósitos da reforma trabalhista, na medida em que deixa os trabalhadores abandonados à própria sorte e, portanto, mais vulneráveis às investidas e interesses do capital que pretende a destruição do trabalho minimamente protegido. A reforma trabalhista possibilitou a devastação dos direitos trabalhistas, entre outros recursos, por meio de subcontratações agora legalizadas.

Com a terceirização da atividade fim, inclusive para o setor público, os concursos públicos para a contratação de docentes podem deixar de ser realizados como já acontece com profissionais como: merendeiras, porteiros e seguranças no âmbito das escolas públicas. A agência Reuters publicou matéria no dia 17 de Maio de 2018 apontando que a Reforma Trabalhista já aparecia nas estatísticas de empre- 
go. A manchete dizia: "Reforma trabalhista limita qualidade do emprego formal e não impede avanço de informais".

Dados do CAGED, do Ministério do Trabalho, mostram que os modelos de contratação parcial e intermitente, criados pela reforma trabalhista, representam fatia cada vez maior do saldo de novas vagas criadas mensalmente, atingindo $11,38 \%$ de todos os postos com carteira de trabalho gerados em março. Foram abertos 6.392 postos intermitentes e parciais em março, diante do total de 56.151 vagas no geral, segundo último dado disponível. A fatia mais que dobrou em relação ao início do ano, quando é possível fazer a primeira comparação com o saldo positivo no CAGED. De modo geral, esses empregos se concentram em funções de baixos salários, como digitador, professores, servente de obras, faxineiro, entre outros, segundo o ministério. (AGÊNCIA REUTERS, 2018)

Na esteira da Reforma Trabalhista e pelo potencial de degradação que ela engendra, alguns municípios ensaiam novas modalidades de contratação tal como é o caso do Município de Angelina em Santa Catarina que chegou a propor uma contratação de serviços pelo "Menor preço Global". Os termos do pregão divulgado, modifica a designação do Professor de Educação Física para "Instrutor de Atividades Físicas".

\section{ESTADO DE SANTA CATARINA \\ PREFEITURA MUNICIPAL DE ANGEUINA}

PREGÃO PRESENCIAL Ne 018/2017

PROCESSO LICITATORIO NE 018/2017

\section{1 - PREÃMBULO}

1 - A Prefeitura do Municipio de Angelina/SC torna público e faz saber que, por determinação de seu Prefeito Municipal, Sr. Gilberto Orlando Dorigon, acha-se aberto o PREGĂO PRESENCIAL NN 018/2017, tipo de licitaçäo a de "MENOR PREÇO GLOBAL", que será processado em conformidade com a Lei Federal n. 10.520/2002, subsidiariamente com a Lei $8.666 / 93$ com suas modificaçōes.

2 - O INICIO DA SESSĀO PÚBLICA DO PREGĀO PARA O RECEBIMENTO DOS ENVELOPES CONTENDO PROPOSTA DE PREÇOS e outro a DOCUMENTAÇĀo será até as 09h00 horas, do dia 06/04/2017.

5 - Este edital refere-se à contratação pela Prefeitura do Municipio de Angelina de prestação de serviços de Instrutor de Atividades Fisicas, de acordo com as quantidades e especificaçōes seguintes:

\begin{tabular}{|c|c|c|c|}
\hline Qtd. & Carga Horária & Descriçāo do objeto & Valor máximo/Mês \\
\hline 1 & $\begin{array}{c}20 \\
\text { horas/semanais }\end{array}$ & $\begin{array}{l}\text { Contratação de serviços de Instrutor de Atividades } \\
\text { Fisicas para o N.E.M. Ermelinda Goederdt Pereira, na } \\
\text { localidade de Rio Novo, e o N.E.M. da Barra Clara. }\end{array}$ & RS $1.200,00$ \\
\hline
\end{tabular}


No cenário que se avizinha, portanto, muitas das tentativas de aplicação de "inovações criativas" para contratação de professores poderão facilmente encontrar respaldo na nova legislação trabalhista, como no caso acima. A presença de organizações sociais, de empresas terceirizadas, por exemplo, poderão introduzir formas de contratação aplicadas no âmbito das empresas privadas na esfera do Estado na medida em que os processos privatização e de parceria público-privada avançarem, o que representará um verdadeiro "drible" nos princípios fixados no artigo 39 da Constituição Federal de 1988.

\section{Considerações finais}

Há um grande movimento que tende a aprofundar a submissão da educação em todos os níveis aos interesses privados ao mercado, justificado pelo falacioso discurso do ajuste fiscal, o que poderá engendrar um quadro de precarização ainda maior para os professores. Procuramos demonstrar, ao logo do texto, que diante de um cenário marcado por uma maior expansão do setor privado na educação tem apresentado uma situação de maior precarização e exploração do trabalho dos professores e como que, com a Reforma Trabalhista, o quadro pode piorar ainda mais.

A combinação da transferência de responsabilidades do Estado para o setor privado com os ditames da Reforma Trabalhista poderá produzir efeitos destrutivos ao trabalho no setor público com significativa supressão de direitos. Os desdobramentos dessa Reforma poderão se expressar numa situação de maior fragmentação da categoria docente, de maior fragilização da organização dos trabalhadores e dos sindicatos, de quebra da isonomia, da instabilidade no trabalho, de redução dos salários e de diminuição drástica dos concursos públicos, isso para citar alguns efeitos.

Os (des) caminhos das reformas educacionais ditados por forças do mercado, tocados pelo governo do golpe, apontam para um cenário no futuro próximo que poderá aproximar professores do setor público e do privado, em condições precárias similares. Para melhor compreensão desse quadro, é preciso olhar para o que vem acontecendo no âmbito do setor privado, quanto aos desdobramentos da reforma trabalhista na qualidade do emprego dos professores, para pen- 
sarmos as pautas de luta e resistência contra o aprofundamento da precarização do trabalho no setor público.

\section{REFERÊNCIAS}

AGÊNCIA REUTERS. Reforma trabalhista limita qualidade do emprego formal e não impede avanço de informais. Disponível em: $<$ https://br.reuters.com/article/businessNews/idBRKCN1II2TFOBRBS>. Acesso em: 20 mai. 2018.

BRASIL. Lei n. 13.467, de 13 de julho de 2017. Altera a Consolidação das Leis do Trabalho (CLT), aprovada pelo Decreto-Lei no 5.452, de 1 o de maio de 1943, e as Leis nos 6.019, de 3 de janeiro de 1974, 8.036, de 11 de maio de 1990, e 8.212, de 24 de julho de 1991, a fim de adequar a legislação às novas relações de trabalho. Disponível em: <http://www.normaslegais.com.br/legislacao/Lei-134672017.htm.> Acesso em: 13 jun. 2018.

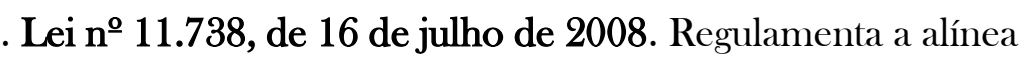
"e" do inciso III do caput do art. 60 do Ato das Disposições Constitucionais Transitórias, para instituir o piso salarial profissional nacional para os profissionais do magistério público da educação básica. 2008.

. Constituição da República Federativa do Brasil. Disponível em: $<$ http://www.planalto.gov.br/ccivil 03/constituicao/constituicao.htm.> Acesso em: 20 jul. 2018.

CNTE. Saiba quais estados brasileiros não respeitam a Lei do Piso. 2016. Disponível em: $<$ http://www.cnte.org.br/index.php/comunicacao/noticias/10757-estados-brasileiros-nao-cumprem-a-lei-do-piso2.html.> Acesso em: 04 jun. 2018.

. Professores sentem a precarização da carreira. 2017. Disponível em: <http://www.cnte.org.br/index.php/cnte-na-midia/18891-professores-sentem-a-precarizacao-da-carreira.html.> Acesso em: 02 mar. 2018. 
FINEDUCA. Nota técnica 1/2016. A aprovação da PEC 241 significa estrangular a educação pública brasileira e tornar letra morta o plano nacional de educação (2014-2024). Disponível em: <http://www.fineduca.org.br/wp-content/uploads/2016/10/Nota-conjunta-FINEDUCACNDE 01 2016.pdf.>

HELOANI, Roberto e BARRETO, Margarida. Assédio Moral: gestão por humilhação. São Paulo: Juruá. 2018.

INEP. Censo Escolar. 2016

PELLISSONA, Cassia Alessandra Domiciano.Cogestão dos centros de educação infantil “Nave-Mãe”: uma parceria público-privada analisada. (Tese de Doutorado). Faculdade de Educação, UNICAMP. Campinas. 2016

PIOLLI, Evaldo e SOUSA, Andrea Luciana Harada. A expansão do ensino superior privado nos anos 1990: educação mercantil e precarização do trabalho docente. In: MARINGONI, Gilberto. O Negócio da Educação: as aventuras das universidades privadas na terra do capitalismo sem risco. São Paulo: Olho dagua/ FEPESP. 2017, pp. 145158. 



\title{
A DISPUTA CULTURAL: O PENSAMENTO CONSERVADOR NO ENSINO MÉDIO BRASILEIRO*
}

\author{
Dirce 赵an \\ Sora Qrawczek
}

As mudanças que, após o golpe de 2016, começam a sofrer a educação brasileira não estão alheias de um processo politico regressivo e de reformas no âmbito das relações de trabalho e de seguridade social. Sem esse cenário teria sido impossível que a educação no Brasil tivesse chegado à situação na qual estamos atualmente. Uma situação que afronta o caráter democrático da escola pública, desvaloriza a ciência, desrespeita a juventude e os trabalhadores da educação.

Na reforma do ensino médio, que foi apresentada em 2016 como medida provisória pelo governo Temer e ficou legitimada na Lei n. $13.415^{1}$ é possível identificar o processo regressivo que a educação brasileira está vivendo e sua conformidade com outras formas de negação do conhecimento à juventude e aos professores.

O ensino médio brasileiro é o elo mais frágil da educação básica e por tanto particularmente sensível a momentos de crises politicas. A sua identidade está em constante debate assim como o caráter que deve assumir sua expansão. A dificuldade de acordar socialmente uma expansão democrática e universalista do ensino médio esteve e continua no centro dos conflitos e tensões quando se tomam decisões sobre o ensino médio. Surge para a formação das elites brasileiras, se expande através da conformação de um sistema dual que destina ao filho do trabalhador a formação profissional sem chance de continuar estudante e quando se desmonta essa estrutura do sistema educativo fortemente segregacionista e novos sectores sociais começam a aceder ao ensino médio, a classe média abandona a escola pública. Possui

"DOI - 10.29388/978-85-53111-28-2-()-f.113-122

${ }^{1} 16$ fev. 2017 
uma infraestrutura precária e uma forte desvalorização docente.

As políticas governamentais, num sistema democrático, resultam em geral de embates e negociações que envolvem diferentes interesses, desencadeando disputas entre forças e projetos, às vezes até antagônicos no atinente aos rumos a serem propostos, neste caso, à educação. Porém, durante o governo Temer, aproveitou-se o clima autoritário que imperou no executivo e no legislativo e tomaram-se decisões que, anteriormente, sofreram forte oposição de vários movimentos sociais e foram objeto de intensos debates no Congresso, sem encontrar consenso.

Neste momento, estamos frente a uma reforma do ensino médio que, sob o manto da palavra de ordem flexibilização, está enfraquecendo o espaço público enquanto espaço educativo e degradando a condição docente.

Em especial no que diz respeito ao projeto das escolas e ao currículo, o tema da flexibilização historicamente se vincula às propostas pedagógicas alternativas. No entanto, ele ganha outra conotação quando associado a um contexto de austeridade econômica e avanço de pensamento conservador, como o que estamos vivendo. Nesse contexto, a flexibilização passa a ser utilizada com a intenção de baratear o ensino (um professor para várias disciplinas de uma mesma área, por exemplo) e restringir projetos formativos a processos de treinamento e instrumentalização técnica.

Entretanto, o uso do termo flexibilização em propostas educacionais contribui para a sedução dos diferentes sujeitos, em especial nesse caso dos jovens estudantes do Ensino Médio, pois costuma remeter, na fantasia das pessoas, à autonomia, livre escolha, espaço de criatividade e inovação. É paradigmático o fato de que a reforma de ensino médio estabelece uma situação totalmente oposta. Estamos frente a uma reforma que em nome da flexibilização exacerba os processos de exclusão e desigualdade social através da desregulamentação, segregação e precarização do ensino e do trabalho docente. ( Krawczyk \& Feretti, 2017)

Desde os documentos curriculares dos anos de 1990 que se busca a reorganização da matriz curricular do Ensino Médio através da aglutinação em áreas das disciplinas tradicionais do currículo. No mesmo sentido de flexibilizar a organização curricular, apresentam 
ainda a possibilidade da oferta de um total de $25 \%$ da carga horária dos cursos de forma diversificada, segundo as culturas e características locais ou das escolas.

$\mathrm{Na}$ reforma educativa atual se estabelece uma nova proposta de organização curricular composta por duas partes, não necessariamente subsequentes, e que em nome da flexibilização, fragmenta o ensino: uma delas destinadas à formação geral do estudante (núcleo comum), com um teto de até 1.800 hs, e uma outra diversificada em 5 itinerários formativos.

O núcleo comum é definido pela Base Nacional Comum Curricular (BNCC), documento ainda não formalmente aprovado, mas que no seu texto referenda algumas diretrizes anunciadas na Lei. Por exemplo, a obrigatoriedade do ensino de matemática, português e inglês e a 'liberdade' dos estados definirem o restante do currículo comum.

No momento em que finalizamos esse artigo, foi homologada pelo atual ministro, uma resolução da Câmara da Educação Básica do Conselho Nacional de Educação, que atualiza as Diretrizes Curriculares Nacionais para o Ensino Médio ${ }^{2}$. Nesse documento, ainda sob revisão, há maiores detalhamentos sobre a oferta dos itinerários formativos, especialmente no que diz respeito à formação técnica e profissional.

Sobre esse tema, salta aos olhos a diversidade na possibilidade de oferta de tal formação. Os arranjos são os mais variados possíveis, o que nos alerta para o perigo em que podem se encontrar a rede recentemente ampliada pelo país dos Institutos Técnicos Federais ${ }^{3}$ e a tradicional rede dos Centros Paula Souza em São Paulo ${ }^{4}$, reconheci-

\footnotetext{
${ }^{2}$ Fonte: <http://agenciabrasil.ebc.com.br/educacao/noticia/2018-11/estados-poderao-decidirse-darao-aulas-distancia-no-ensino-medio $>$

${ }^{3}$ Como parte de um projeto de desenvolvimento tecnológico, econômico e social a expansão da Rede Federal de EPT (Educação Profissional e Tecnológica) teve início por meio da Lei $n^{\circ}$ 11.195, de 18 de novembro de 2005. A primeira fase da expansão previa a construção de 64 novas unidades com objetivo de ampliar a rede federal em todo território nacional, em especial, nas periferias de grandes centros urbanos e em municípios do interior do país (MEC/SETEC, 2011). A segunda fase foi lançada em 2007 com objetivo de criar mais 150 novas unidades. Ao fim da segunda fase, em 2010, eram 214 novas unidades! (SANTOS e ZAN, 2018...)

${ }^{4}$ Segundo noticiado no Jornal O Estado de São Paulo em novembro de 2017 Disponível em <http://educacao.estadao.com.br/noticias/geral,sao-paulo-vai-testar-escolas-tecnicas-inspiradasna-reforma-do-ensino-medio.> Acesso em 26 nov. 2018
} 
das instituições que contribuem para formação técnica e profissional de qualidade.

A resolução detalha também os outros itinerários formativos e remete à necessária consonância entre o currículo do Ensino Médio e o documento da BNCC que ainda não foi aprovado pelo CNE.

Outro ponto do texto sobre a Reforma do Ensino Médio que merece destaque, diz respeito à abertura para a oferta desse nível de ensino através da Educação a Distância. Junto a homologação da alteração das DCNEM, o CNE também aprovou que até 20\% da carga horária do ensino médio diurno, até $30 \%$ no noturno e até $80 \%$ na modalidade de Educação de Jovens e Adultos, podem ser ofertadas em EAD. A regulação e o "controle" dessa oferta serão feitos por cada estado, segundo o MEC.

A forte redução do tempo e conteúdos de formação geral e a flexibilização na forma de oferta desse nível de ensino, explicitam claramente o sentido instrumental da formação pretendida e a preocupação com a melhoria dos indicadores do Brasil nos testes internacionais. Além disso, deixa cada vez mais clara a intenção de promover uma aproximação com o setor privado para a viabilização da oferta desse nível de ensino, tornando mais atrativa para as empresas educacionais essa atuação.

A redução do tempo e conteúdo da formação comum a todos não é uma demanda dos jovens, tal como se intenta convencer através da mídia. Isto está demonstrado nas mobilizações juvenis que buscam, sobretudo, serem autônomos e críticos, possuir os conhecimentos científicos e culturais.

Mas, a reforma educativa de ensino médio está inserida num movimento mais amplo de forte enfrentamento ao caráter cultural e científico da escola pública. A escola está vivendo situações que remontam há quase 100 anos atrás, e que estão sendo lideradas pelo movimento Escola sem Partido.

O avanço do pensamento conservador na disputa pela escola não é algo genuinamente nacional e retoma batalhas que imaginávamos já superadas.

Nos anos de 1920, um professor foi processado criminalmente no sul dos Estados Unidos porque estava ensinando a teoria da evolução das espécies de Darwin a seus alunos. Segundo seus acusadores, 
isso contrariava a bíblia segundo o qual o homem e a mulher haviam sido criados por Deus há cinco ou seis mil anos a partir de um boneco de barro ${ }^{5}$.

Apple (2003) tem acompanhado o avanço do pensamento conservador nos EUA dominando e influenciando a sociedade em geral e a política e prática educacionais, em particular. Para ele, o país está enfrentando um amplo movimento de "modernização conservadora" que recomenda "libertar" as escolas, incluindo-as num mercado competitivo, restaurar a cultura tradicional comum e enfatizar a disciplina e o caráter, voltando-se para a doutrina cristã nas salas de aula como guia de toda conduta dentro e fora da escola. Ao mesmo tempo, o movimento defende a intensificação e o controle dos professores por meio de critérios de avaliação e testes mais rigorosos e exigentes.

Algo similar temos vivido aqui no Brasil desde o Golpe de 2016 e que se intensifica com a eleição de Jair Bolsonaro que, de certo modo, deu novo fôlego à tramitação do Projeto Escola sem Partido nas diferentes casas legislativas. Professores são denunciados porque ensinam educação sexual nas aulas de biologia, ou marxismo nas aulas de filosofia. Escolas são denunciadas porque utilizam livros que retratam aspectos da cultura africana, ou por discorrer sobre diversidade, são só alguns dos exemplos que cotidianamente estão acontecendo em nossas escolas. Também está colocada a pressão para que as escolas ensinem algo que tem sido chamado de 'criacionismo', ou seja, retornar ao ensinamento bíblico sobre Adão e Eva, em conjunto com a evolução das espécies, apresentando-as como duas hipóteses (científicas) de surgimento da humanidade. Isto é, equiparar a religião à ciência e, em muitos casos, proibindo o ensino da ciência nas escolas. Por exemplo, se formos para o campo das ciências humanas como no caso da história vamos encontrar quem defende a negação da ditadura militar no Brasil, a negação da importância de Paulo Freire para a educação popular no País, entre outros.

Com o ataque às ciências humanas, - seja por via da exclusão da carga horária e das disciplinas obrigatórias e da carga horária para formação geral, seja pela exclusão do currículo de filosofia e sociolo-

\footnotetext{
${ }^{5} \mathrm{Em} 1960$ foi lançado o filme "O vento será tua herança”, dirigido por Stanley Kramer, que retrata essa história e era também uma crítica ao macarthismo norte-americano dos anos 50 .
} 
gia, seja pelas denúncias do suposto viés ideológico das escolas - pretende-se tirar da escola seu sentido democrático e critico. É a negação do papel educativo da escola de transcender o espaço privado da família e de formação da cidadania. Lembremos que a escola pública estatal é uma construção histórica da Idade Moderna junto ao processo de secularização da educação (Luzuriaga, 1959)

Todas essas estratégias se aproximam do que é relatado por Apple (2003) sobre a atuação da direita, isto é, são ações que têm como principal intenção mudar nosso senso comum, alterando o significado das categorias mais básicas que empregamos para compreender o mundo social e educacional e o nosso lugar nele, o que se relaciona diretamente à política de identidade. A direita tem se concentrado em alterar radicalmente aquilo que pensamos ser e como nossas principais instituições devem responder a essa alteração de identidade.

A crise do neoliberalismo no século XXI serviu como uma luva para difundir e fortalecer o movimento conservador pelo mundo. De certo modo, é possível afirmar que a disputa por agendas econômicas atuais se constrói por meio de uma guerra que é fundamentalmente discursiva e cultural e, portanto, a escola e a ciência são alvos privilegiados nesse momento.

Voltemos à reforma do ensino médio e sua proposta de organização curricular em várias opções formativas

A reforma curricular, concebida na Lei n. 13.415 de 16/02/2017, é uma nova forma de distribuição do conhecimento socialmente produzido, colocando o ensino médio a serviço da produção de sujeitos técnica e subjetivamente preparados do ponto de vista instrumental, tendo em vista os interesses do capital. Daí a pouca atenção voltada à formação de sentido amplo e crítico, ou sua secundarização, assim como a exclusão, como obrigatórias, de disciplinas como filosofia e sociologia. Da mesma forma, é importante ressaltar o silêncio em relação às artes na formação desses estudantes.

Ao mesmo tempo, se amplia a penetração de ideias e ideais neoliberais na formação dos estudantes. Temas como o do empreendedorismo passam a se fazer presentes nos diferentes documentos e projetos formativos. Na resolução que altera as DCNEM homologadas nesse ano de 2018, o empreendedorismo aparece como um dos eixos estruturantes da formação nos cinco itinerários formativos. Nes- 
se documento o empreendedorismo é assim apresentado: supõe a mobilização de conhecimentos de diferentes áreas para a formação de organizações com variadas missões voltadas ao desenvolvimento de produtos ou prestação de serviços inovadores com o uso das tecnologias (artigo 12, parágrafo $2^{\underline{0}}$, inciso IV).

É o discurso e a lógica do mercado se fortalecendo na formação dos estudantes do Ensino Médio. Onde anteriormente se compreendia como eixo estruturante o trabalho coletivo, a solidariedade e o compromisso social na formação dos estudantes, agora se coloca como parte inerente de toda e qualquer formação princípios como o do empreendedorismo e da inovação, fortemente vinculados à perspectiva do mercado produtivo.

Mas, essas mudanças não estão acontecendo sem contradições. Existe disputa e conflitos existentes também nesse campo conservador. Por exemplo, a mesma resolução apresenta na sessão referente à estrutura curricular, maiores detalhamentos sobre a parte comum do currículo do Ensino Médio em que se expressa a organização em quatro áreas: linguagens e suas tecnologias, matemática e suas tecnologias, ciências da natureza e suas tecnologias e ciências humanas e sociais aplicadas. No inciso IV, parágrafo $4^{\circ}$, explicita que deverão ser contemplados “estudos e práticas” de arte, especialmente em suas expressões regionais; conhecimento do mundo físico e natural e da realidade social e política, especialmente no Brasil; história do Brasil, considerando a contribuição das diferentes culturas e etnias, especialmente das matrizes indígena, africana e europeia e história e cultura afro-brasileira e indígena.

É também nas políticas voltadas para a formação de professores que podemos observar o avanço do pensamento conservador e da disputa entre projetos educacionais. $\mathrm{O}$ avanço na oferta de cursos de formação de professores através das instituições privadas e, principalmente, na modalidade de Educação a Distância. Ao mesmo tempo, há uma tentativa de forte interferência no currículo dos cursos de formação de professores das Universidades Públicas reconhecidamente instituições responsáveis por oferta de ensino de qualidade.

Recentemente no estado de São Paulo, o Conselho Estadual de Educação (CEE), através de deliberações, visa implementar uma concepção bastante instrumental da formação desse profissional nos 
currículos das instituições públicas de ensino. Sob o argumento de que os estudantes da educação básica possuem um baixo desempenho nos exames em larga escala e que esse fato resulta da má formação dos professores, o CEE propõe uma verdadeira intervenção nos cursos das universidades públicas paulistas. As deliberações do CEE sobre o tema, apresentam um forte caráter de interferência curricular, no conteúdo a ser ministrado, nos tempos específicos, no superdimensionamento da responsabilidade das universidades estaduais com a formação desse profissional.

O tema da formação de professores é central diante de uma política de construção e consolidação de um pensamento conservador, como a que estamos vivendo.

Ao analisar o fenômeno nos EUA, Diniz-Pereira (2008), apresenta a disputa entre grupos neoliberais e neoconservadores na orientação da formação desses profissionais naquele país. A disputa pela formação dos professores tem se manifestado seja através da flexibilização do espaço formativo (próprio local de trabalho, nas instituições de ensino superior) seja na defesa de uma formação técnica e neutra desse profissional. Além disso, há uma estrutura de controle do trabalho do professor que cresce e se fortalece a partir dos vários exames em larga escala. Essa política de racionalização da formação e do trabalho docente, contribuem para a desqualificação dos professores devido à intensificação do trabalho e a perda de autonomia e respeito.

Junto a isso, o movimento Escola sem Partido que tem estimulado a censura e o policiamento das ações dos professores em sala de aula, contribuem para o crescimento de atritos entre estudantes e educadores, entre o aprofundamento de uma relação de desconfiança e de hostilidade entre família e escola. Num contexto em que a profissão tem sido pouco atrativa para jovens estudantes brasileiros, tememos que o clima atual contribua para maior resistência ainda à profissão.

\section{Considerações finais}

Vale lembrar a alerta que faz Apple (2003) ao estudar o movimento de "modernização conservadora" nos EUA. Os movimentos direitistas reconheceram que para vencer no Estado é também preciso 
vencer na sociedade civil e, para tanto, estão em busca de realizar um projeto educacional que contribua para a consolidação da pauta econômica.

Faz-se necessário reconhecer que alguns dos argumentos desses grupos são ouvidos exatamente porque estão conectados com aspectos da realidade vivida pelas pessoas, ou seja, que eles têm conseguido, de algum modo, se articular a temas que ressoam profundamente em experiências, temores, esperanças e sonhos das pessoas em sua vida cotidiana.

Importa que retomemos nosso projeto e nossa atuação cotidiana na disputa por essa conexão, ou seja, pela referência aos ideais progressistas como aqueles que contribuirão para a superação das desigualdades e da violência social. Nessa luta, a escola e, em especial, o ensino médio são estratégicos e potentes para a contraposição a esse projeto cultural conservador. Portanto, a disputa por agendas econômicas do século XXI se constrói por meio de uma guerra que é fundamentalmente discursiva. É uma guerra pelo estabelecimento de novos discursos.

\section{REFERÊNCIAS}

APPLE, Michael. Educação à Direita: Mercados, Padrões, Deus e Desigualdade. SP: Cortez/Instituto Paulo Freire, 2003.

DINIZ-PEREIRA, Júlio. Formação Docente nos Estados Unidos: aliança conservadora e seus conflitos na atual reforma educacional norteamericana. In Educação \& Sociedade, v. 29, n. 102, jan/abr 2008.

ESTADO DE SÃO PAULO. Conselho Estadual de Educação. Deliberação n. 157 de 26 de dezembro de 2016.

LUZURIAGA, L. História da educação pública. Tradução e notas: Luiz Damasco Penna; J. B. Damasco Penna. 2. ed. São Paulo: Companhia Editora Nacional, 1959. (Atualidades Pedagógicas). v.71.

MINISTÉRIO DA EDUCAÇÃO. Conselho Nacional de Educação. Resolução n. 2 de $1^{\circ}$ de julho de 2015. 
KRAWCZYK, N. e FERRETTI, C. Flexibilizar para quê? As meias verdades da reforma do ensino médio. Brasília: Retrato da escola, v.11, n 20 .

SANTOS, Danielle e ZAN, Dirce. Ensino Médio e Educação Profissional: o marco das criações dos Institutos Federais de Educação, Ciência e Tecnologia, in SARTÓRIO, Lúcia; LINO, Lucília e SOUZA, Nádia (orgs.) Política educacional e dilemas do ensino em tempos de crise: juventude, currículo, reformas do ensino e formação de professores. SP: Editora Livraria da Física, 2018. 


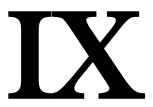

\section{FORMAÇÃO DE PROFESSORES: O ESTADO PÓS- DEMOCRÁTICO, A DITADURA E OS GOLPES DE 1964 E 2016 NO BRASIL *}

Srima @. Sspigolon

É o segundo golpe de Estado que enfrento na vida. O primeiro, o golpe militar, apoiado na truculência das armas, da repressão e da tortura, me atingiu quando era uma jovem militante. $\mathrm{O}$ segundo, o golpe parlamentar desfechado hoje por meio de uma farsa jurídica, me derruba do cargo para o qual fui eleita pelo povo.

Dilma Rousseff

Este texto intenciona, por um lado, apresentar componentes que problematizem as relações que permeiam a vida e de projetos de formação de professores aliados à justiça social, dignidade e amorosidade. Por outro, enfocar aspectos dos golpes de 1964 e 2016 como possibilidade de leituras do real. Tanto a leitura quanto a feitura destas páginas para o "Curso Livre o golpe de 2016 e a Educação no Brasil”, são entendidas por mim como processos de formação, como potência político-pedagógica no campo dos cursos de licenciatura que formam formadores, sobretudo, em uma Faculdade de Educação.

A minha apresentação/o meu texto com os temas geradores (FREIRE, 1967): o golpe de 1964, a ditadura, o golpe de 2016, o Estado Pós-Democrático e a formação de professores justificam-se tanto pelo seu caráter histórico de discussão de fatos passados, quanto pela ponte com o futuro na propagação de visões de mundo construídas no

"DOI - 10.29388/978-85-53111-28-2-()-f.123-140

${ }^{1}$ Fonte: $<$ https://www.dw.com/pt-br/\%C3\%A9-o-segundo-golpe-de-estado-que-enfrento-diz-dil$\underline{\mathrm{ma} / \mathrm{a}-19517215>}$ Acesso em 08 out. 2018 
cotidiano de práticas sociais repletas de utopias capazes de constituir sociedades mais igualitárias ao se posicionar a favor de uma educação emancipadora, pública e socialmente referenciada e contra governos autoritários e o intolerável da opressão, da violência e da censura.

\section{Golpes de Estado (1964 e 2016) e ditaduras no Brasil}

A ditadura sobreviveu a 1964 e no âmbito dos golpes de Estado instaurados no Brasil faz emergir questões que tencionam os cenários políticos, sociais, econômicos e culturais tanto a época quanto agora. Cenários que com o golpe de 2016 fragilizam a democracia brasileira, em construção e, podem ser melhor compreendidos no escopo do neoliberalismo e do neoconservadorismo.

A fragilização do Estado Democrático de Direito atravessado pela realidade histórica do país, por visões de mundo e práticas que priorizam o capital financeiro e os privilégios de pequenos grupos dominantes, elegendo o consumo e a mercantilização dos direitos sociais para o setor privado é totalmente contrária ao que preconiza a Constituição da República do Brasil. Essa ambiência cria um Estado Pósdemocrático, cuja principal característica é a ausência de limites ao exercício do poder e a onipotência das elites.

De fato, na pós-democracia (DARDOT \& LAVAL, 2016) e no Estado Pós-Democrático (CASARA, 2017), o significante "democracia” tem substituído a participação popular nas decisões políticas ao lado dos agentes estatais para a materialização dos direitos e garantias fundamentais por um conjunto de ações necessárias à repressão e à violência à população indesejada, à multiplicação dos lucros e à acumulação. O neoliberalismo e o recrudescimento das forças conservadoras estão conduzindo à era pós-democrática.

O caráter golpista de 1964 e de 2016 e o Estado Pós-Democrático vigente, nacional e internacional, interferem política e pedagogicamente na formação de professores, pois as concepções de Estado e de políticas (públicas) sociais num determinado tempo histórico sustentam ações e programas de intervenção. Concepções de sociedade, Estado, política educacional produzem projetos e realidades diferentes de intervenção no campo da formação de professores. 
Os afastamentos impostos, via golpe, aos presidentes brasileiros eleitos através do voto popular, João Goulart em 1964 e Dilma Rousseff em 2016 interromperam projetos sociais e populares que representavam outra perspectiva de governar, mais democrática e mais humana, representavam caminhos mais originais a partir da América Latina e ao resto do mundo.

A tomada intencional desses governos democraticamente eleitos revela a tradição autoritária, a hegemonia do capital estrangeiro e a influência dos governos norte-americanos que vem até hoje transformando drasticamente a sociedade brasileira dentro da lógica neoliberal compatível, inclusive, com a transformação das mentalidades/sensibilidades em mercadoria, conduzindo ao agravamento da exclusão social, o aumento avassalador da violência (não só física, como também da violência estrutural, produzida pelo próprio funcionamento do Estado Pós-Democrático), a inviabilidade da agricultura familiar, a destruição do meio ambiente, a perseguição aos movimentos sociais, a militarização do medo.

Detidamente, os assombrosos contornos da deposição da presidenta Dilma Rousseff em 2016 se estendem a várias configurações, sem deixar incólume os setores públicos da saúde, da educação, dos direitos trabalhistas e, por que não dizer, as dimensões da existência humana. Instalou-se a política do ódio e a ausência de reflexão gera o modelo de pensamento bélico-binário, que "ignora a complexidade dos fenômenos e divide as pessoas entre amigos e inimigos" (CASARA, 2017). Em linhas mais gerais, no Estado Pós-Democrático há a progressiva desconsideração, ou mesmo a eliminação, dos atores jurídicos, o abandono do sistema de vínculos legais, a afirmação dos interesses midiáticos de massa, a mudança do paradigma do próprio sistema de corrupção e da efetiva liberdade de imprensa, a utilização do poder penal para excluir e neutralizar os discordantes da nova ordem estabelecida, a diminuição das ações afirmativas e das políticas inclusivas e o aumento das medidas penais de controle e exclusão.

Contornos que me fazem, sem assombro, cantar com Milton Nascimento a canção de 1981 - Caçador de mim, pois sua voz, com a minha voz e, com outras fazem ecoar "Nada a "temer" senão o correr da luta; nada a fazer senão esquecer o medo”. 


\section{A Educação Pública e o Estado Pós-Democrático}

Aqui, convido o Professor Paulo Freire, e toda a potência contida em sua compreensão crítica de Educação, cuja dialeticidade implica, pois, na conscientização da realidade e o compromisso em transformá-la de modo a se tornar menos desigual, mais justa e mais amorosa.

Quero com isso e quero que essa potência possa com sua práxis revolucionária contribuir para as relações emancipadoras e dialógicas entre os sujeitos, entre eles e o mundo e a vida. Quero com isso e quero que essa resistência seja a lutar por uma educação pública, laica, gratuita e de qualidade, socialmente referenciada. Quero com isso assumir a posição política de pesquisar, tendo em vista o caráter propositivo e reflexivo de uma Educação, pensada e re-pensada, criada e re-criada, a partir da ditadura brasileira, dos golpes de 1964 e 2016 e de um Estado Pós-Democrático.

Sob a inspiração do professor Paulo Freire (1978) todo ato pedagógico é ato político e a Educação não é um fazer neutro. Portanto, ter esse curso e trabalhar com o tema nessa faculdade de Educação não é um fazer neutro e, sim é um fazer que assume posicionamentos.

Ao assumir posições que mais assertivamente definem uma concepção dialética e dialógica de formação de professores, humanizadora, de que quem educa (ensina e aprende) marca o corpo do outro. Somos seres de relação. É no atritar dos sujeitos em movimentos, em contradições, em reflexões e inflexões que aprendemos e ensinamos porque somos seres humanos e nos tornamos humanos através do ato de conhecer o mundo, de metamorfosear as nossas visões de mundo, ou seja, nossa episteme, nossos processos de "humanização" são marcados por relações que vivenciamos nas experiências da nossa vida. $\mathrm{E}$ isso não pode se dar descolado do campo da formação humana e da formação de professores, é preciso ir além das metodologias e dos métodos de ensino.

A democracia e a Educação devem se aproximar cada vez mais da realidade para transformá-la coletivamente e, em razão da mercantilização do mundo, do autoritarismo extremo e da sociedade do espetáculo, romper com o dualismo teoria/prática cuja produção do professor como atributo da profissão seja prioritariamente, na relação 
com o aprendiz e não com o conhecimento, como um artesanato intelectual e relacional.

Na medida em que o Estado Democrático de Direito se encontra cada vez mais sob ameaça e o Estado Pós-Democrático se consolida, a Educação pode intermediar as leituras e os processos do real não só por questões ideológicas, mas também pela facticidade inerente aos projetos de formação de professores indissociáveis do ensino, da pesquisa e da extensão e que sejam voltados à realização dos direitos e garantias fundamentais, à articulação de diferentes tempos e espaços da vida social, o cuidado afetivo com o outro integrado à diversidade, a criticidade reflexiva, as dimensões do sensível e os sentidos das experiências... a formação de professores como processos e projetos que emancipam humanidades.

Como trazer para as licenciaturas essas provocações do Estado Democrático de Direito ao Estado Pós-Democrático? Como pautar a formação de professores em tempos de ranqueamento em larga escala e em escala mundial? Como trabalhar sob censura, Lei da Mordaça e Escola sem partido, temas como o Estado de Exceção, os Golpes de 1964 e 2016 ?

Seria a existência em frangalhos, a re-existência ou a resistência? Ou seria a utopia ${ }^{2}$ ? Ou seria mesclas delas? Ou não seria uma ou outra? O que seria? O que será que será?

É desafiador e angustiante ver cada vez mais perto os acontecimentos do golpe de 1964 no Brasil e a ditadura instaurada que lemos nos livros de história e de literatura, que assistimos nos depoimentos e nos filmes e, que eu particularmente pesquisei no Doutorado ${ }^{3}$, acontecendo em tempo real é algo nefasto, que beira o inacreditável. Vivemos, de novo e, mais uma vez, sob as noites da ditadura e os dias de utopia.

\footnotetext{
${ }^{2}$ Operamos com o conceito de utopia como parte da realidade, já que é a partir do que se vive que se projeta sonhos e esperanças de um futuro melhor tecido nos movimentos possíveis de transformação (FREIRE, 2000; GALEANO, 2007; LEFEBVRE, 2008; PEPETELA, 1997; VAZQUEZ, 2001).

${ }^{3}$ SPIGOLON, Nima I. As noites da ditadura e os dias de utopia - o exílio, a educação e os percursos de Elza Freire nos anos de 1964 a 1979. 2014. Faculdade de Educação, UNICAMP, Campinas.
} 


\section{De João Goulart a Dilma Rousseff: golpe é sempre golpe}

Para pensar, sentir, agir e relacionar-se com a Educação Pública, a Formação de Professores, o Estado Pós-Democrático, a Ditadura e os golpes de 1964 e 2016 no Brasil:

Quando um General vem a público, com a maior desfaçatez, e afirma que em certas circunstâncias caberia ao Exército dar um golpe para proteger a democracia brasileira, precisamos discutir sobre a Ditadura no Brasil. Quando autoridades públicas, políticos, jornalistas e parte da população vem a público bradar que os direitos humanos são ideologia e que seus defensores devem ter a mesma sorte dos "bandidos que defendem", ou seja, a morte, precisamos discutir sobre a Ditadura no Brasil. Quando um ex-Presidente é condenado sem provas e a ele é imposto um processo de julgamento reconhecidamente inconstitucional, é preciso que discutamos o legado autoritário deixado pela Ditadura e que ainda hoje marca nossas instituições judiciárias. [...]. Em que o assassinato de lideranças políticas populares é tratado como fato corriqueiro pelas forças de segurança, em que parte da população defende abertamente a "volta dos militares”. Em que, mais uma vez, o combate à corrupção é justificativa para a suspensão das garantias constitucionais. [...]. Derrotada a Ditadura, não foram poucos os momentos em que os ideais democráticos e os direitos humanos foram postos no frontispício de nossos planos de educação e nos programas e currículos escolares. Foram elaboradas propostas muito generosas a respeito desses temas e grande expectativa se criou sobre o poder de a escola pública contribuir para a construção da normalidade democrática e para o respeito aos Direitos Humanos. E realmente muito foi feito nessa direção. Mas, certamente não foi o suficiente. [...]. É por isso mesmo que não podemos recuar (Editorial, Jornal Pensar a Educação, abril de 2018).

Golpe de Estado é derrubar ilegalmente um governo constitucionalmente legítimo. Tem este nome de golpe, porque se caracteriza por uma ruptura institucional repentina, contrariando a normalidade da lei e da ordem e submetendo o controle do Estado a determinados grupos que não haviam sido legalmente designados, seja através de eleição, hereditariedade ou outro processo de transição. Os golpes, 
cercam ou tomam de assalto a sede do governo, expulsando, prendendo ou até mesmo executando os membros do governo deposto.

Golpe é sempre golpe. Contando com o alinhamento de interesses. Golpe vincula-se ao uso violento do aparelho do Estado. No Brasil, com relação ao período de 1964 até 1985, há de se destacar o papel relevante atribuído às Forças Armadas, assim como à "tecnoburocracia”, passa a ser atribuído aos empresários, e banqueiros e aos setores mais conservadores da Igreja e das elites. E com relação a 2016 até agora segue a marca histórica do momento em que a hegemonia política e ideológica iniciada no primeiro governo Lula se viu sitiada por um aparelho jurídico, policial e midiático sem precedentes.

Condenar sem crime é golpe. Golpe de classe, militar e parlamentar. Golpe significa violar a constituição e trair a soberania popular por força da qual Dilma Rousseff se elegeu com 54 milhões de votos e João Goulart que propôs um programa de governo que incluía uma série de reformas institucionais que atuariam sobre problemas estruturais do país, denominadas "reformas de base" destacavam-se as reformas agrária, educacional, fiscal, eleitoral, urbana e bancária.

Ontem em 1964 e hoje em 2016, seja por via militar seja por via parlamentar, funciona a mesma lógica: as elites econômico-financeiras e a casta política conservadora praticam a pilhagem de grande parte da renda nacional. Souza (2016) aponta 71.440 pessoas, apenas $0,05 \%$ da população contra a vida e o bem-estar da maioria do povo, submetido à pobreza e à miséria.

Em 1964 o golpe de Estado foi responsável pela deposição do Governo do presidente João Goulart o que levou ao Brasil em anos e anos de ditadura militar, com desaparecimentos, torturas, prisões e mortes. Além disso, os militares com o apoio de blocos do poder (DREIFUSS, 2008) não conseguiram só levar adiante o regime que estava em vigor, mas também continuar no poder até 1985 (FERNANDES, 1975; GORENDER,1987; BAUER, 2012; TOLEDO,1983).

Em 2016 o processo de destituição contra a presidenta Dilma Rousseff, considerando dentre outros, o poder estrutural do capital financeiro e as contradições inerentes aos modelos de crescimento econômico e coalizão política observados desde o governo Lula, a unificação da burguesia em torno a um programa neoliberal e neoconservador a partir do governo Dilma, assim como a relação entre a revolta 
das camadas médias e o ataque político-judicial resultante no golpe de Estado (BASTOS, 2017). O golpe de 2016 foi desferido também a uma mulher, fato inegável, todavia, a reflexão sobre gênero no Brasil e a importância das mulheres para a democracia brasileira, ficou relegada à margem como uma questão menor. (ARGOLO \& RUBIM, 2018). O Golpe de 2016, concentra-se no afastamento da primeira mulher democraticamente eleita presidente do Brasil, Dilma Rousseff, que gerou debates inflamados em torno da economia e da corrupção, que denunciou a inconformação de setores mais conservadores da sociedade em torno da ausência de um consorte de político, ou de um par conjugal, de um primeiro-cavalheiro. Dilma foi, sozinha e separada, uma chefe de Estado e chefe de Governo.

Como trazer para as licenciaturas essas problematizações da destituição dos Governos de João Goulart (1964) e de Dilma Rousseff (2016)? Como pautar a formação de professores em tempos de reformas nas quais as questões de gênero são acusadas de doutrinação? Como trabalhar sob censura e sob a Base Nacional Comum Curricular (BNCC)? Como pedagógica e politicamente trabalhar temas tais: o movimento LGBT; a educação para a diversidade; os marcadores sociais de sexo, de raça e de classe; as cotas sociais, indígenas e raciais?

Seria a existência em frangalhos, a re-existência ou a resistência? Ou seria a utopia? Ou seria mesclas delas? Ou não seria uma ou outra? O que seria? O que será que será?

Fatos que desembocam nesse "território em desagregação" (SAFATLE, 2017) que é em sua maioria o Brasil atual, quando o medo paralisa a ação política e outros desafios se colocam a cada nova e inesperada medida, como por exemplo: atuar no campo da formação de professores.

Em regimes democráticos, golpes são movimentos sediciosos, que recrudescem inicialmente por poucos conspiradores. Há depois que se criar a mobilização da opinião pública e, se cumprir rituais, formalismos, imprimindo aparência de legalidade ao golpe, e por fim, que seja, no mínimo convalidado por um dos dois poderes da República - o Supremo Tribunal Federal (STF) ou o Congresso (NASSIF, 2014).

Os dois episódios de golpe, 1964 e 2016, revelam o desprezo e o medo que as classes dominantes têm pela democracia e pela von- 
tade popular, revelam como os períodos de democracia no Brasil têm sido marcados por dinâmicas de avanços e retrocessos.

\section{A Ditadura é o intolerável e a Educação é a luta contra os intole- ráveis e a intolerância}

Ditadura é um regime governamental onde todos os poderes do Estado estão concentrados em um indivíduo, um grupo ou um partido. $\mathrm{O}$ ditador não admite oposição a seus atos e ideias, e tem grande parte do poder de decisão. É um regime antidemocrático onde é vedada a participação da população.

A ditadura possui vários aspectos de regimes de governo totalitários e/ou autoritários e de uma política de terrorismo de Estado ${ }^{4}$. Geralmente, a ditadura é implantada através de um golpe de estado. Ou seja, a ditadura vem atrelada ao Golpe. A ditadura é uma política de Estado, junto com a violência e o medo, implantada no Brasil com o golpe de 1964.

A ditadura brasileira é matriz para as demais na América Latina. Lá se foram Argentina, Bolívia, Chile, Paraguai, Uruguai, o Cone sul. Como parte escancarada e declara da Operação Condor liderada pelos Estados Unidos. A ditadura no Brasil foi a mais longa dos países latino-americanos. Foi a única que negou passaporte e documentos civis aos exilados, dentre outras táticas de repressão e estratégias de perseguição, destacadamente o exílio (SPIGOLON, 2014).

No Brasil, diretamente afetado pelas injunções do processo sócio histórico em decorrência dos golpes de 1964 e 2016 teve em ambos a instauração de um Estado de exceção. Há um conjunto de ações que caracterizam os Estados de exceção instaurados por golpes. Passamos então a ter por exemplo, em 1964 com Atos Institucionais (AI); cassação de direitos políticos dos tidos subversivos ou perigosos; re-

\footnotetext{
${ }^{4} \mathrm{O}$ referencial bibliográfico (YANKELEVICH, 2007; SAID, 2003 e 2007; ROLLEMBERG, 1999) com o qual trabalho não diferencia terrorismo e autoritarismo de Estado considerando características comuns: subordinação dos poderes judiciário e legislativo ao executivo; repressão a oposição política e ideológica ao governo, cassação dos direitos individuais, estado de exceção, entretanto, reconheço que alguns autores operam com marcadores que distinguem estes regimes. Arendt (1990), por exemplo, faz distinções para sistemas ou regimes autoritários e ditaduras totalitárias, e utiliza os exemplos da Itália fascista, a União Soviética Stalinista e a Alemanha nazista.
} 
pressão aos movimentos populares e sociais; manifestações de proibição contrárias à liberdade; cerceamento aos meios de comunicação; censura aos artistas, intelectuais; estudantes e militantes; alinhamento ao imperialismo norte-americano; controle dos sindicatos; implantação do bipartidarismo com oposição controlada; enfrentamento armado aos movimentos de guerrilha adversos ao governo vigente; uso de métodos violentos de punição, tortura, prisão, desaparecimentos e mortes; expulsão, exílio e banimento dos opositores e considerados contrários à moral e à ordem pública estabelecida. E em 2016 quais as ações que são recorrentes?

Não há como ignorar as semelhanças de 1964 com a conjuntura do golpe de 2016, por exemplo: como em 1964, não há crime de responsabilidade contra Dilma Rousseff, assim como não existia qualquer alusão criminosa a João Goulart. Quando da deposição de Jango, a classe trabalhadora foi duramente prejudicada, com a redução brutal do salário mínimo, a perda da estabilidade no emprego, a intervenção nos sindicatos e cassação de dirigentes sindicais combativos, limitação no processo de contratação coletiva, proibição de aumentos salariais pelos Tribunais Trabalhistas, criminalização das greves e punição dos grevistas. Quando da destituição de Dilma representou um retrocesso social, uma diminuição de garantias e direitos sociais, uma violência sem precedentes para a classe trabalhadora e para as camadas sociais mais rejeitadas da população. João Goulart e Dilma Rousseff foram perseguidos implacavelmente por uma mídia comprometida com interesses antidemocráticos, associada às camadas dominantes e comprometida com políticos apartados dos ideais republicanos.

Voltam ao cenário: as questões energéticas; o desmonte da Petrobras, objeto de interesse transnacional; as nossas reservas do PréSal; a corrida pela privatização das empresas estatais, com a transferência de ativos e concessões amplas em diversas as áreas de logística e infraestrutura; a desvinculação do orçamento público para a desobrigação com saúde e educação e a diminuição dos investimentos com políticas públicas. Voltam ao cenário: a perseguição à Educação, o ataque aos cursos de formação de professores, a desvalorização do profissional da Educação, o "notório saber" na Educação que desonera o Estado de seu dever e o cidadão do seu direito, o cerceamento di- 
dático-pedagógico, o currículo vigiado e patrulhado, tempos "temerários" para professores, principalmente da área de humanas.

Depois do golpe de 1964 incontáveis educadores, professores e intelectuais da área da Educação passaram a ser perseguidos em decorrência de posicionamentos ideológicos, políticos e pedagógicos e a partir de 1968 estudantes. Muitos deles responderam inquéritos e depois, retidos nos cárceres e porões, muitos foram torturados e silenciados pelo extermínio de suas vidas, muitos forçados ao exílio, muitos ficaram reclusos à vida privada, muitos demitidos, exonerados e cassados... em todos eles o profundo descaso e desrespeito para com o professor e para com a formação de professores, em todos eles as marcas dos golpes de Estado e da ditadura que perduram até os dias atuais. Que a memória de outrora e de agora, sombria, sangrenta e dolorida do passado e do presente fortaleçam a luta, a resistência e a esperança e sejam capazes de ressignificar a democracia, a existência humana e a Educação.

Num movimento de caleidoscópio, retorno ao panorama da sociedade brasileira no pré-64 e rente a ele. A conjuntura econômica, a luta pelas reformas sociais nas dimensões políticas e ideológicas, os movimentos populares e culturais, o papel dos militares, inclusive o pensamento da esquerda brasileira na Educação, a participação norteamericana e o alinhamento ao capital estrangeiro, os conflitos entre os blocos de poder e a força das concepções golpistas presentes no país são alguns dos aspectos que dialogam em horizontalidade com a Educação e os projetos de formação de professores ainda na contemporaneidade. Os vestígios do período e da ditadura no Brasil e na Educação registram os confrontos das forças militares, políticas e sociais, que utilizavam recursos com censura, terrorismo, tortura e até no presente, perseguição política, ideológica e repressão aos que eram e são contrários aos ideais do governo em vigência.

Vidas e percursos de vida alterados drasticamente. A ditadura brasileira de 1964 foi uma das consequências do aparato violento utilizado pelo regime de governo que se manteve no poder por mais de duas décadas de autocracia (1964/1985), ele atingiu indistintamente homens, mulheres, crianças, jovens e adultos que saíram do país, em virtude de se tornarem alvo da ditadura e da repressão. Foram inquéritos, prisões, intervenções, desaparecimentos, torturas e mortes. 
Além de promover a mudança drástica na estrutura governamental e suprimir a democracia que vinha acontecendo, o período foi profundamente marcado pelo autoritarismo e terrorismo de Estado utilizados como métodos para conter e tentar eliminar uma certa vida política que marcou as gerações de 1964 e 1968 e que representavam resistência, oposição e garantia da manutenção de uma nova ordem que foi ditada ao país.

A ditadura é o intolerável. A Educação e os processos potencializados por ela, ajuda-nos a vivenciar o enfrentamento e o pensamento necessários na luta contra os intoleráveis e a intolerância.

Dentre esses processos, os de formação de professores em todos os níveis e modalidades de ensino, que representam um ato de resistência e de coragem; anunciam e denunciam as paixões e os desafios de ensinar e aprender e vice-versa. E em tempos-espaços tão diversos e controversos, como os seres humanos se inscrevem na realidade? Em realidades plurais? Tais interrogações em torno de um mundo em ininterruptas alterações, conseguem pôr em relações dialéticas os contextos educacionais, culturais, sociais e institucionais, considerados tempos-espaços de formação e transformação.

\section{Golpe, ditadura, Educação, formação de professores}

Golpe, ditadura, Educação, formação de professores e o golpe de 1964. Por que o abuso do poder e da força que fez exacerbar a violência? Para que serviu a coerção e a perseguição? Por que e para que os acordos MEC-USAID que enquadraram o ensino brasileiro nos moldes estadunidenses? Quais as razões de se instituir uma metodologia tecnicista e liberal da Educação? Por que se formou um sistema de ensino que se afunilava, dando acesso restrito às elites aos níveis superiores? Para que se interrompeu as experiências de alfabetização de adultos de Paulo Freire - coordenador do Programa Nacional de Alfabetização (1964), cujas principais inovações eram a substituição das cartilhas e livros-texto por um trabalho pedagógico com "palavras geradoras" e com a ênfase na relação dialógica com as experiências de vida dos professores, estudantes e grupos sociais? No auge de 1964, o Brasil fervilhava com projetos educacionais humanistas e emancipadores que sofreram diretamente os impactos da repressão. O golpe de 1964 
perseguiu, sistemática e violentamente, os professores/educadores cujo pensamento e engajamento classificava subversivos e contrários aos tidos como "interesses nacionais".

Golpe, ditadura, Educação, formação de professores e o golpe de 2016. Em que medida esse Estado de Exceção instaurado impacta as políticas nacionais de formação de professores? Há uma agenda internacional que regula as políticas de formação de professores? O que as políticas públicas voltadas para a formação de professores elegem como prioridade? Como os cursos de licenciatura pautam a formação de professores? Quais os projetos de formação de professores são encampados pela universidade pública? O que queremos como política pública para a formação de professores e professoras? E mais uma vez, a Educação no bojo das políticas públicas e sociais, se destaca na pauta de um conjunto de arbitrariedade em execução desde o golpe de 2016 no Brasil para o desmanche do Setor Público e a instauração de um Estado de Exceção subserviente aos interesses do Capital e da hegemonia ideológica que reconhece no outro uma ameaça retrocedendo à barbárie e à violência.

Tanto em 1964 quanto em 2016, as questões sociais e as desigualdades continuam, são angústias existenciais. Interrogar, dialogar e refletir sobre isso é uma arte do fazer, uma poesia da utopia, é em suma se aproximar cada vez mais de quem somos e em quais projetos societários nos inserimos.

O golpe de 1964 no Brasil e a ditadura são cicatrizes históricas, como qualquer outra cicatriz, insiste em mostrar algo que talvez não se queira ou se tente esconder. Incômoda, marca o país, o corpo e a memória, ela faz lembrar para que não se tornem Legião dos esqueci$\operatorname{dos}^{5}$.

No Brasil e na América Latina, as décadas 1960 e 70 são marcadas por acontecimentos políticos, sociais e econômicos golpeados por ditaduras de caráter civil-militar que provocaram rupturas de projetos desenvolvimentistas. Isto alterou, de forma significativa, a realidade de pessoas e países (MAZZA \& SPIGOLON, 2018). Após a primeira década do século XXI, no Brasil e na América Latina, as crises neodesenvolvimentistas (BOITO JR. \& BERRINGER, 2013) convivem com a ofensiva conservadora das políticas e das reformas neolibe-

${ }^{5}$ A vida do viajante. Luiz Gonzaga e Gonzaguinha. Gravadora EMI-Odeon. Brasil, 1981. 
rais e com a instabilidade da democracia, configurando-se em crises não provocadas pela ascensão dos movimentos populares e nem por lutas trabalhistas.

Entre o golpe de 1964 e o de 2016 permanece o fato de que procedem da mesma natureza estrutural. Ambos são golpes de classe, dos detentores do capital e do poder: o primeiro usa os militares, o outro o parlamento. As intermediações são distintas, porém, resultam em golpes com ruptura democrática e violação das forças populares. São inflexões e reflexões em torno da vida política brasileira nas últimas décadas dialogando com as dinâmicas globais do capitalismo e o extenuar das esquerdas.

Como herança para as próximas gerações talvez eu queira deixar que a utopia é a realização no tempo atual e que a memória não se refere apenas ao passado. Ela é presente e futuro. Essa temática, o golpe de 1964 e a ditadura no Brasil embora com ares de passado, dizem respeito aos lugares do presente. E esse encontro dela com o golpe de 2016 e o Estado Pós-Democrático me fazem manifestar que a formação de professores é prescindível para não perdermos a capacidade de indignação e de transformar dialeticamente as utopias. Seremos a memória dos dias que virão.

Em uma cronologia que marca inomináveis ataques à Educação e à docência, em que direitos são relegados e que o ser humano se questiona sobre a vida, as razões de viver e o mundo em que vive, ser professor é lutar por outros períodos de tempo e melhores condições para existir. Ser professor hoje, em todos os níveis e em todas as modalidades de ensino, é um ato de resistência daqueles que acreditam que ainda há esperança e, de que, as mudanças são possíveis.

Nas páginas da nossa história republicana, os golpes de Estado contra as frágeis instituições políticas do país se constituíram em ameaça permanente que quando consumados desmantelaram organizações político-partidárias e reprimiram movimentos sociais de esquerda e progressistas. Os golpes foram saudados pelas classes dominantes e seus ideólogos. Todavia, a formação de professores, é fundamental para dimensionar a perversa, brutal e devastadora ruptura praticada contra os processos de construção da democracia em curso no Brasil. As escolas, as instituições educativas, precisam acessar materiais, informações, produções qualificadas sobre esses capítulos do Brasil. Os 
professores, os educadores, os profissionais da Educação, os estudantes, os educandos, precisam ter resguardados o uso pedagógico e político de fontes de pesquisa referenciadas de como o golpe de 1964, a ditadura e o golpe de 2016, marcaram tempos, lugares, pessoas sem exclusão ou exceção no país afora e ainda marcam as memórias da gente.

\section{Faz escuro mas eu canto}

Os golpes que atingiram João Goulart (1964) e Dilma Rousseff (2016) chegam até mim, chegam até nós. Eles sangram os direitos humanos, a democracia, a Educação. Eles tentam interceptar projetos emancipadores e políticas públicas humanizadoras de formação de professores. E agora, por que não nomear a esperança como esperança vermelha?

Recordo o poeta, ex-preso político, o amazonense Thiago de Mello. Quando o golpe de 1964 aconteceu no Brasil, narra ele (2006) que morava em La Chascona, casa de Pablo Neruda, em Santiago no Chile e que ouviu o pronunciamento de João Goulart (que ainda estava em Brasília) ao lado do poeta chileno e do futuro presidente Salvador Allende. Com a instauração da ditadura no Brasil em 1964, a vida para Thiago e um contingente de brasileiros mudaram radicalmente. $\mathrm{Na}$ ocasião em que esteve preso, deparou-se com um de seus versos escritos na parede da cela: "Faz escuro mas eu canto/ Porque a manhã vai chegar". Era o sinal de que sua luta incessante pelo respeito à vida humana encontrava eco e precisava ser levada adiante.

Tanto lá quanto cá, escritos em um momento em que o Brasil atravessava tempos de obscurantismo, e lidos agora, em que o Brasil novamente enfrenta tempos sombrios, os poemas são tingidos por esperança que encanta e acalenta o coração inquieto da humanidade.

E nós, como estamos escrevendo a nossa participação nesse momento histórico?

As sociedades se transformam, fazem-se e desfazem-se. Os golpes de Estado, as ditaduras, as tecnologias mudam o trabalho, a interação, as mídias, a vida cotidiana e mesmo o pensamento e as lutas. As desigualdades se deslocam, agravam-se e recriam-se em novas fronteiras, além dos territórios conhecidos. Os sujeitos se vinculam a múlti- 
plos campos sociais e a contemporaneidade impede a qualquer um de nós de proteger-se dos conflitos do mundo e das contradições do Estado Pós-Democrático. São angústias existenciais, pedagógicas e políticas. Quais as lições que daí podemos trazer para a formação de professores?

A memória, os ataques à Democracia, as violações dos direitos humanos, o descaso para com a Educação Pública, são como mapas, biografias da resistência e memoriais da formação de professores em nosso país. Seremos a memória dos dias que virão. Decidi que a sala de aula é meu principal tempo-espaço de resistência e que a formação (humana) de professores e a minha própria são companheiras de luta a qual chamamos vida.

\section{REFERÊNCIAS}

ARENDT, Hannah. Origens do totalitarismo. Tradução: Roberto Raposo. São Paulo: Companhia das Letras, 1990.

ARGOLO, Fernanda \& RUBIM, Linda (Org.) O golpe na perspectiva de gênero. Salvador: Editora da Edufba, 2018.

BAUER, Carlos. A natureza autoritária do Estado no Brasil contemporâneo. Elementos de história e questionamentos políticos. São Paulo: Sundermann, 2012.

BASTOS, Pedro Paulo Zahluth. Ascensão e crise do governo Dilma Rousseff e o golpe de 2016: poder estrutural, contradição e ideologia. Revista de Economia Contemporânea. vol.21, Número Especial: p. 1-63, 2017.

BOITO JR., A.; BERRINGER, T. Brasil: classes sociais, neodesenvolvimentismo e política externa nos governos Lula e Dilma. In: Revista de Sociologia e Política, n.47, p.94-109, 2013.

CASARA, Rubens R. R.. Estado Pós-Democrático - Neo-Obscurantismo e Gestão dos Indesejáveis. Rio de Janeiro: Editora Civilização Brasileira S/A, 2017.

DARDOT, Pierre e LAVAL, Christian. A nova razão do mundo: ensaio sobre a sociedade neoliberal. São Paulo: Boitempo Editorial, 2016. 
DREIFUSS, R. A. 1964: a conquista do Estado - ação política, poder e golpe de classe. Petrópolis: Vozes, 2008.

FERNANDES, Florestan. A revolução burguesa no Brasil: ensaio de interpretação sociológica. Rio de Janeiro: Editora Jorge Zahar, 1975.

FREIRE, Paulo. Educação como prática da liberdade. Rio de Janeiro: Paz e Terra, 1967.

- A alfabetização de adultos: é ela um que fazer neutro? In:

Educação \& Sociedade, nº 1. São Paulo: Cortez, 1978.

. Pedagogia da Indignação: cartas pedagógicas e outros escritos. São Paulo: Editora UNESP, 2000.

GALEANO, Eduardo. As palavras andantes. Porto Alegre: L\&PM, 2007.

GORENDER, J. Combates nas trevas. A esquerda brasileira: das ilusões perdidas à luta armada. São Paulo: Ática, 1987.

JORNAL BRASIL DE FATO. Geral. Universidades que ofertaram Cursos sobre o Golpe de 2016. Disponível em < https://www.brasildefato.com.br/2018/05/16/universidades-que-ofertaram-cursos-sobre-ogolpe-de-2016-se-reunem-em-curitiba/.> Acesso em 08 ago. 2018

JORNAL PENSAR A EDUCAÇÃO. Belo Horizonte. Editorial: Educação, Ditadura e Direitos Humanos. Ano 6 - № 192, 06 de abril de 2018. Disponível em <http://pensaraeducacao.com.br/pensaraeducacaoempauta/edicao192/> Acesso em 10 abr. 2018

LEFEBVRE, Henri. Espaço e política. Belo Horizonte: Ed. UFMG, 2008.

MAZZA, Débora \& SPIGOLON, Nima I.. Educação, exílio e revolução: o camarada Paulo Freire. In: Revista Brasileira de Pesquisa (Auto)Biográfica, Salvador, v. 03, n. 07, p. 93-110, jan./abr. 2018.

MELLO, Thiago de. Faz escuro mas eu canto. $1^{\underline{a}}$ Edição. Rio de Janeiro: Editora Civilização Brasileira, 1965.

. Entrevista. Brasil, 2006. Disponível em <http://www.vermelho.org.br/noticia/3776-1> Acesso em 10 abr. 2018 
NASSIF, Luis. História do golpe: $\mathrm{o}$ xadrez da batalha do impeachment. 2014. Disponível em <https://jornalggn.com.br/noticia/historiado-golpe-o-xadrez-da-batalha-do-impeachment-por-luis-nassif $>$ Acesso em 09 set. 2018

PEPETELA -Artur Carlos Maurício Pestana dos Santos-. A geração da utopia. Lisboa: Dom Quixote, 1997.

ROLLEMBERG, Denise. Exílio entre raízes e radares. Rio de Janeiro: Editora Record, 1999.

ROUSSEFF, Dilma. Entrevista. Brasil, 2016. Disponível in $<$ https://www.dw.com/pt-br/\%C3\%A9-o-segundo-golpe-de-estado-queenfrento-diz-dilma/a-19517215> Acesso em 08 ago. 2018

SAID, Edward. Reflexões sobre o exílio e outros ensaios. Tradução Pedro Maia Soares. São Paulo: Companhia das Letras, 2003.

. Humanismo e crítica democrática. Tradução Rosaura Eichenberg. São Paulo: Companhia das Letras, 2007.

SAFATLE, Vladimir. Só mais um esforço. São Paulo: Três Estrelas, 2017.

SOUZA, Jessé. A radiografia do golpe. São Paulo: Leya, 2016.

SPIGOLON, Nima I. As noites da ditadura e os dias de utopia - o exílio, a educação e os percursos de Elza Freire nos anos de 1964 a 1979. 2014. 506f. Tese (Doutorado em Ciências Sociais na Educação). Faculdade de Educação, UNICAMP, Campinas.

TOLEDO, C. N. de. O governo Goulart e o golpe de 1964. São Paulo: Brasiliense, 1983.

VÁZQUEZ, Adolfo Sánchez. Entre a realidade e a utopia: ensaios sobre política, moral e socialismo. Rio de Janeiro: Civilização Brasileira, 2001.

YANKELEVICH, Pablo; JENSEN, Silvina (Orgs.). Exilios: destinos y experiências bajo la dictadura militar. Buenos Aires: Libros Del Zorzal, 2007. 


\title{
X \\ O GOLPE E A GESTÃO DEMOCRÁTICA DAS ESCOLAS
}

\author{
Pristiane Crachado \\ Chara Qegina CKantins Sacomeli
}

Este artigo tem o objetivo de sistematizar o debate sobre as implicações do golpe na gestão democrática das escolas públicas, encetado no Curso livre "O golpe de 2016 e a Educação no Brasil”, realizado na Faculdade de Educação da Universidade Estadual de Campinas - UNICAMP, entre março e junho de 2018.

Para promover e estimular os argumentos expostos na mesa que analisou a temática da relação do golpe com a gestão democrática, foi feito no Google um levantamento ${ }^{1}$ de entrevistas e reportagens do Ministro da Educação à época, Mendonça Filho, sobre a política educacional implementada e de artigos que examinaram criticamente o golpe e a situação do país no pós-golpe.

Nunca é demais (re)afirmar: foi golpe! A despeito do discurso dos seus apoiadores de que o processo seguiu os trâmites constitucionais, foi aprovado tanto na Câmara como no Senado e garantiu o amplo direito de defesa, dentre outras justificativas, concordamos com Braz (2017, p. 88) que o advento do golpe que destituiu a Presidenta eleita Dilma Rousseff foi "forjado por uma farsa parlamentar-judicial".

Barbé (In: BOBBIO, 1998, p. 545-547), analisando o conceito Golpe de Estado, informa que o conceito sofreu transformações ao longo do tempo. Para o autor, "o fenômeno em nossos dias manifesta notáveis diferenças em relação ao que, com a mesma palavra, se fazia referência três séculos atrás". Explica que "as diferenças vão, desde a mudança substancial dos atores (quem o faz), até a própria forma do ato (como se faz)"; entretanto, ressalta: "apenas um elemento se man-

*DOI - 10.29388/978-85-53111-28-2-()-f.141-152

${ }^{1}$ Realizado por Larissa Barbosa Ferreira, Mestranda da Faculdade de Educação da UNICAMP, a quem agradecemos. 
teve invariável, apresentando-se como o traço de união entre estas diversas configurações: o Golpe de Estado é um ato realizado por órgãos do próprio Estado”, exatamente como se observou no golpe de 2016.

Há que se considerar, ainda, que o golpe alçou aos cargos do Ministério da Educação partidárias notórias do PSDB - justamente o partido que havia acabado de perder as eleições presidenciais de 2014 em disputa fortemente acirrada com Dilma Rousseff, candidata do Partido dos Trabalhadores (PT), eleita com 51,64\% dos votos válidos contra 48,36\% do candidato do Partido da Social Democracia Brasileira (PSDB), Aécio Neves -, como Maria Helena Guimarães de Castro, que assumiu a Secretaria Executiva da pasta. A ascensão, ao poder executivo, do partido derrotado nas eleições é mais uma constatação cabal de que foi golpe. É o "golpe dentro do golpe", como constatou Luiz Carlos de Freitas (2018) em seu blog. Para ele, a participação de pessoas reconhecidamente dos quadros políticos do PSDB no Ministério da Educação "é um golpe na educação dentro do golpe jurídicoparlamentar o que coloca oportunistamente em cena um programa educacional recusado nas urnas”.

Neste contexto, esse artigo intenciona expor elementos da política educacional proposta pelo governo golpista e examinar eventuais implicações para a gestão democrática das escolas públicas.

\section{Sobre gestão democrática}

Acalentada no bojo do pujante movimento político-social de redemocratização do país durante a década de 1980, tendo em vista a proximidade do encerramento do nefasto ciclo da ditadura militar (1964-1985) no Brasil, a gestão democrática das escolas públicas se configurou como preceito legal com a promulgação da Constituição Federal de 1988.

O artigo 206 da Carta Magna estabelece os princípios do ensino, e o inciso VI deste artigo determina "a gestão democrática do ensino público” como uma das bases para educação escolar nacional. Posteriormente, a Lei de Diretrizes e Bases da Educação Nacional de 1996, Lei Federal 9.394, ratificou essa orientação legal no inciso VIII 


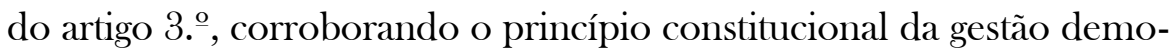
crática do ensino público.

Mais recentemente, a Lei Federal 13.005, de 25 de junho de 2014, que aprovou o Plano Nacional de Educação (2014-2024), reafirmou, no inciso VI do artigo 2.․․ a gestão democrática da educação pública como uma das diretrizes na educação nacional e estabeleceu na meta 19 "a efetivação da gestão democrática da educação" como uma das 20 metas para a condução da educação no país no decênio. Além disso, indicou 8 estratégias para a consecução da meta dentro do prazo estipulado na lei.

É inegável a trajetória do aperfeiçoamento legal na garantia da gestão democrática das escolas; no entanto, sabe-se que é na prática cotidiana da gestão escolar que a gestão democrática se efetiva, se constrói e se consolida. Porém, cabe definir a concepção de gestão democrática do ensino escolar que acolhemos como parâmetro para qualquer contenda sobre o tema. Antes, importa destacar que a compreendemos como um processo político. Processo no sentido etimológico de sua origem latina: procedere, formada pelos vocábulos pro, que significa "à frente", e cedere, "ir", o que resulta no sentido de "mover adiante, avançar" - uma construção diária e paulatina, que possui momentos históricos de prolongamentos e, também, de recuos. Político, por se tratar de um campo eivado de poder, como todo processo democrático. De acordo com Bobbio (2000, p. 10), "pode-se definir a democracia das maneiras as mais diversas, mas não existe definição que possa deixar de incluir em seus conotativos a visibilidade ou transparência do poder".

O objetivo de enfatizar o entendimento de gestão democrática como processo político é frisar seu caráter prático que, aportado como princípio na legislação, precisa de movimento, de ação para se concretizar e se realizar nas escolas públicas.

A propósito, a concepção de gestão democrática que mais nos parece adequada ancora-se nos pressupostos de Souza (2009), para o autor, gestão democrática é um processo político no qual todas as pessoas que convivem no espaço escolar "identificam problemas, discutem, deliberam e planejam, encaminham, acompanham, controlam e avaliam o conjunto das ações voltadas ao desenvolvimento da própria escola na busca da solução daqueles problemas”. Ressalta, ainda, que 
esse processo se sustenta no diálogo, no respeito, no reconhecimento das diferenças de todas as ordens e deve ter, na participação efetiva de todos os segmentos da comunidade escolar, seu ancoradouro, além do "respeito às normas coletivamente construídas para os processos de tomada de decisões e a garantia de amplo acesso às informações aos sujeitos da escola” (SOUZA, 2009, p. 125-126).

Essa conjuntura nacional de expansão e fortalecimento da gestão democrática das escolas públicas, especialmente no âmbito legal, impulsionada pela promulgação da Constituição de 1988, contrasta com o contexto internacional marcado por uma intensa crise do capital iniciada na década de 1970. Em 1973 o colapso do petróleo e a consequente recessão econômica em escala global resultaram na urgência de uma profunda reestruturação das forças produtivas, que redimensionou os elementos constitutivos do tripé que sustenta o sistema capitalista, conforme Antunes (2005), capital, trabalho e Estado. A reorganização de todas as dimensões estruturantes do capital advinda deste processo teve agudos desdobramentos nas políticas educacionais.

No Brasil, os processos de reestruturação - de forma planejada, organizada e sistemática - do tripé capital, trabalho e Estado tiveram início na década de 1990, mais especificamente no governo de Fernando Henrique Cardoso e adotaram como paradigma os critérios da economia privada na gestão dos órgãos e dos sistemas públicos. Estudos e pesquisas apontam a existência de uma "nova regulação nas políticas educativas que tem interferido na organização e gestão da educação, passando pelas várias mediações dos sistemas educacionais, mas com forte acento na escola" (OLIVEIRA; DUARTE; CLEMENTINO, 2017, p. 708). Corolário dessa conjuntura, a atuação do gestor escolar tem sido instada por dois diferentes projetos de sociedade: de um lado, a determinação do preceito legal da gestão democrática do ensino público que pressupõe debate, planejamento coletivo, socialização de informações, participação, dentre outras; e, de outro, os processos de reestruturação do Estado que impelem as ações gestoras para a utilização dos princípios gerenciais das empresas privadas no espaço escolar, o que é incompatível com a gestão democrática do ensino. 
Como contraponto aos ideais de privatização da educação pública, há que se revigorar a gestão democrática do ensino público, conforme conquista expressa na Constituição Federal de 1988, o que supõe estimular espaços e oportunidades de discussão nas escolas, sobre as escolas, envolvendo todos os segmentos que transitam na instituição escolar. Esse é o desafio premente.

\section{Sobre educação pós-golpe}

É possível supor que o embasamento do governo que usurpou o poder com o golpe de 2016 seja o documento de 19 páginas, intitulado "Uma ponte para o futuro", lançado - como agenda política do Partido do Movimento Democrático Brasileiro (PMDB), partido do vice-presidente Michel Temer, na Fundação Ulysses Guimarães (FUG) sediada em Brasília -, em 29 de outubro de 2015, exatos 10 meses antes da destituição de Presidente eleita Dilma Rousseff do cargo.

Cavalcanti e Venerio (2017), com o uso do software "TagCrowd" para a geração de "nuvem de palavras" (word cloud) dos termos mais frequentes em um texto, fizeram um estudo das cerca de 6.630 palavras que compõem o documento e verificaram que as palavras mais citadas são: público (45 vezes), economia (39 vezes) e fiscal (38 vezes). Com base nessas informações, concluíram: "percebe-se no documento uma grande preocupação com a crise fiscal (diminuição dos recursos carreados aos cofres públicos) e com a rigidez do orçamento ('dificuldade' para alocação dos recursos)". Ressaltam, ainda que, de acordo com o texto, a solução deveria

[...] passar pelo crescimento econômico, pela reforma do orçamento [...], pela redução da taxa básica de juros e pela reforma da Previdência Social, principalmente com a revogação da indexação dos benefícios pelo salário mínimo (desindexação) e com o aumento da idade mínima para a aposentadoria (CAVALCANTI; VENERIO, 2017, p. 155-156).

Pelo exposto, fica evidente que há, claramente, uma preocupação com o saneamento (?) da economia do país e o reconhecimento da necessidade de adoção de medidas de austeridade e nenhuma, mas nenhuma mesmo, preocupação com a educação. Afirmação que 
se consolida como realidade a cada dia que passa desses pouco mais de 24 meses de governo golpista.

$\mathrm{Na}$ divisão dos ministérios entre os partidos que apoiaram o golpe, coube ao Democratas (DEM) a pasta da Educação. Divisão esta que foi feita já durante o afastamento de Dilma Rousseff para o prosseguimento do processo que resultou no impeachment em agosto de 2016. O empresário e deputado federal pernambucano, José Mendonça Bezerra Filho, assumiu o Ministério da Educação em maio de 2016 de forma provisória e, em agosto, de forma definitiva. Filho do também político e latifundiário, José Mendonça Bezerra, que foi deputado estadual pela ARENA por três mandatos e deputado federal pelo PFL por sete mandatos, Mendonça Filho é um típico representante da elite nordestina brasileira.

Entretanto, como já dito aqui, os cargos da pasta foram loteados com pessoas sabidamente ligadas ao PSDB, como Maria Helena Guimarães de Castro, que assumiu a Secretaria Executiva. Comentando as nomeações para o Ministério da Educação, Luiz Carlos de Freitas (2016) em seu blog observa que o Ministro indicado era "ignorante da área da educação" e, por essa razão, se viu "obrigado a entregar o Ministério ao PSDB”. Ponderou, ainda, que “este partido não quer titularidade nos ministérios do governo Temer, mas quer o controle, na prática, da política desenvolvida pelo governo. Se der certo, mérito do PSDB, se não der, culpa do PMDB. Típico do tucanato”. Fernando Haddad, opinando sobre o mesmo tema em entrevista para a Carta Capital (PAIVA, 2016) parece corroborar a afirmação de Freitas (2016) ao declarar: "entendo que quem vai dar as cartas sobre o projeto político pedagógico será o corpo técnico, já que o ministro ficará na articulação política”.

Com este time (?) em campo, a tônica do Ministério da Educação foi o autoritarismo na proposição de iniciativas que deveriam passar pelo crivo das entidades e categorias envolvidas e a retomada de políticas educacionais latentes da época que Fernando Henrique Cardoso era presidente, como disse Guiomar Namo de Melo durante entrevista ao Ministro da Educação no programa Roda Viva, da TV Cultura: "finalmente vamos poder resgatar o que era efetivamente o projeto de educação necessária para o Brasil e que foi interrompido” (MATHIAS, 2017). 
Alguns meses após assumir a pasta da Educação e 22 dias depois de assumir em definitivo do Ministério da Educação, Mendonça Filho decretou, inicialmente por medida provisória (MP 746 de 22.09.2016) e, posteriormente, por força de lei (Lei Federal 13.415 de 16.02.2017) que alterou artigos da LDB 9.394/1996, a reforma do ensino médio. Cabe ressaltar que esse movimento foi eivado de severas críticas, por se tratar de uma reforma educacional que não considerou o debate com os formais representantes da sociedade no congresso nacional.

Na entrevista concedida ao Roda Viva, em outubro de 2016, o Ministro, desconsiderando o mal-estar causado pelo processo autoritário desencadeado, apresentou duas justificativas para a reforma do ensino médio. Primeiramente, afirmou que as medidas tomadas vieram ao encontro do que a sociedade pedia, nas palavras dele: "o fato de termos aprovado com maioria indica que era algo que não apenas os alunos queriam". Esse ponto de vista, indubitavelmente, nos remete à análise de Fernandes (1975) que, examinando a dependência na América Latina, concluiu que os interesses particularistas das elites sempre são considerados como os interesses da sociedade brasileira. A outra justificativa foi relacionada ao contingente de jovens que não estudam. Quando perguntado que nota daria para a educação no país, o Ministro respondeu: "com certeza abaixo de cinco, quatro. Eu não posso imaginar que uma Educação que convive com 1,7 milhão de jovens fora do Ensino Médio, jovens que nem trabalham nem estudam possa ter uma nota de aprovação". Estranhamente, reportagem no site do G1 (MORENO, 2018) com base nos dados da PNAD do IBGE mostrou que essa população aumentou, de 2016 para 2017, em 1,2\%: o contingente era de 21,8\% em 2016 e chegou em 23\% em 2017. Ao que parece, a iniciativa do Ministro não atingiu o objetivo almejado de atrair os jovens para a escola...

Sobre o conteúdo da reforma do ensino médio, dentre os vários pontos que merecem análise acurada, vale ressaltar o acréscimo do inciso IV, que cria a figura "profissionais com notório saber", ao artigo 61, que define quem são os "profissionais da educação escolar básica". Os "profissionais com notório saber", de acordo com o texto da lei, poderão atuar na formação técnica e profissional dos estudantes, para "ministrar conteúdos de áreas afins à sua formação ou expe- 
riência profissional, atestados por titulação específica ou prática de ensino em unidades educacionais da rede pública ou privada ou das corporações privadas em que tenham atuado”. Em suma, a legislação permite que quem não é professor possa atuar como professor. Essa mudança na LDB, conjuntamente com outras reformas feitas no governo golpista, especialmente a trabalhista, tem contribuído para o aprofundamento da precarização do trabalho na educação, principalmente o trabalho docente. Afinal, quem não se lembra do pregão presencial para professor de educação física, em um município do estado de Santa Catarina, no qual os candidatos deveriam apresentar, em envelope fechado, proposta inferior ao salário máximo oferecido de $1.200,00$ reais por 20 horas semanais de trabalho? (BASILIO, 2017b).

A formulação da Base Nacional Comum Curricular (BNCC), exigência da Constituição Federal de 1988, da Lei de Diretrizes e Bases da Educação Nacional de 1996, começou a ser discutida no primeiro semestre de 2015, ainda no governo Dilma, em abril de 2017. Mendonça Filho finalizou o documento e o enviou ao Conselho Nacional de Educação para aprovação. O texto, muito coerente com ideias e propostas historicamente defendidas pelos representantes do PSDB no MEC, evidencia um ensino-aprendizagem voltado para a formação de habilidades, competências, procedimentos e formação de atitudes, em detrimento do foco em conteúdos escolares e na importância e no papel do trabalho educativo; tem o objetivo de adaptar os estudantes ao mercado de trabalho, com ênfase no empreendedorismo, e demonstra uma concepção fragmentada do conhecimento e do desenvolvimento humano, desconsiderando as diversidades e as especificidades de aprendizagem dos estudantes.

De forma unilateral, em maio de 2017 o Ministro editou o decreto, publicado em 09.05.2016, ainda no governo Dilma, que convocava a Conferência Nacional de Educação (CONAE) para o primeiro semestre de 2018, e revogou as deliberações anteriores adotadas pelo Fórum Nacional de Educação (FNE). As atribuições deste colegiado formado por entidades representativas da sociedade civil foram repassadas para a Secretaria Executiva do Ministério da Educação. Além disso, em portaria posterior, alterou a composição do Fórum Nacional de Educação, excluindo entidades representativas de segmentos como 
o campo, a pesquisa em educação e o ensino superior. Em contrapartida, aumentou a participação de representantes do empresariado e de entidades afinadas com o governo ou mesmo controladas por ele (BASILIO, 2017a).

Igualmente de forma unilateral, em outubro de 2017, o Ministro lançou a Política Nacional de Formação de Professores, anunciando que a iniciativa era "algo simples, prático, mas, ao mesmo tempo, revolucionário” (MATHIAS, 2017). Entretanto, novamente foi severamente criticado pela forma de proposição da medida. Ao ser entrevistada, a presidente da Anfope advertiu que as entidades representativas da área não estavam a par de qualquer discussão sobre o novo desenho da política e ressaltou:

[...] essa tem sido a prática do governo, o grande interlocutor do MEC são fundações privadas criadas por bancos e cervejarias que não entendem de educação; não são as entidades educacionais, as instituições formadoras e os próprios professores. Como a Política pode ir ao encontro da demanda de quem está na ponta se o MEC não foi ouvir os professores? (MATHIAS, 2017).

O ponto alto da passagem de Mendonça Filho no Ministério da Educação ficou por conta do evento de sua saída do cargo, em 28 de março deste ano. Ao discursar, agradecendo o trabalho desenvolvido, Temer, não se sabe se por descuido ou excesso de sinceridade, disse ter certeza de que Mendonça "continuará fazendo discursos em outros cargos que vier a ocupar” (GOVERNO..., 2018).

\section{Notas finais}

Ao finalizar, cabe retomar o objetivo inicial deste artigo originado no debate sobre as implicações do golpe na gestão democrática das escolas públicas, no Curso livre "O golpe de 2016 e a Educação no Brasil".

Vale ressaltar que os golpistas usurparam o poder e governam de costas para o povo e para os preceitos democráticos da sociedade conquistados na Constituição de 1988, atuam com uma pauta baseada em medidas de austeridade que subtraem direitos da classe trabalhadora, confiscam políticas sociais básicas conquistadas e arrocham salá- 
rios, sem, no entanto, contrariar interesses dos grandes grupos econômicos e do capital financeiro.

Sabe-se que não é possível ser democrático sendo autoritário, fomentar a participação sem criar oportunidades de diálogo. Assim, um governo que se pautou no autoritarismo só pode arrefecer os processos de implementação da nossa balzaquiana redemocratização, resvalando, por decorrência, no enfraquecimento dos processos democráticos nas escolas públicas.

Como exposto, a gestão democrática é um processo político que se ancora na garantia e pressupostos legais, mas que se efetiva na ação, na prática, no cotidiano do movimento de construção da própria gestão democrática nas escolas. Para esse movimento se fortalecer e contribuir com a ampliação da democracia na sociedade mais ampla, é fundamental o estímulo e fomento dos órgãos governamentais objetivando valorizar procedimentos e iniciativas que sobrelevem os preceitos democráticos na educação.

É urgente a finalização deste período sombrio da nossa história e a retomada da construção dos processos democráticos e democratizantes que se pautem, respeitem, reconheçam e incrementem as decisões coletivas, tanto na sociedade como nas escolas.

\section{REFERÊNCIAS}

ANTUNES, Ricardo. Os sentidos do trabalho. São Paulo: Boitempo, 2005 .

BASILIO, Ana Luiza. Governo dissolve Fórum Nacional de Educação e restringe participação da sociedade. Carta Capital. Carta Educação. Reportagens, 4 maio 2017a. Disponível em: <http://www.cartaeducacao.com.br/reportagens/governo-dissolve-forum-nacional-de-educacao-e-restringe-participacao-da-sociedade/> Acesso em: 12 jun. 2018.

. Professores sentem a precarização da carreira. Carta Capital. Carta Educação. Reportagens, 16 ago. 2017b. Disponível em: $<$ http://www.cartaeducacao.com.br/reportagens/professores-sentemprecarizacao-da-carreira/>. Acesso em: 20 ago. 2017. 
BOBBIO, Norberto. Dicionário de política. Brasília: Editora Universidade de Brasília, 1998.

. O futuro da democracia: uma defesa das regras do jogo. 6. ed. São Paulo: Paz e Terra, 2000.

BRASIL. Constituição da República Federativa do Brasil, 1988. Brasília, DF: Senado Federal, 1988.

. Lei no 9.394, de 20 de dezembro de 1996. Estabelece as diretrizes e bases da educação nacional. Diário Oficial da União, Brasília, DF, 21 dez. 1996.

. Lei no 13.005, de 25 de junho de 2014. Aprova o Plano Nacional de Educação - PNE e dá outras providências. Diário Oficial da União - Seção 1 - Edição Extra, n. 120-A, p. 1, Brasília, DF, 26 jun. 2014.

BRAZ, Marcelo. O golpe nas ilusões democráticas e a ascensão do conservadorismo reacionário. Serv. Soc. Soc., São Paulo, n. 128, p. 85-103, jan./abr. 2017.

CAVALCANTI, Bernardo Margulies; VENERIO, Carlos Magno Spricigo. Uma ponte para o futuro?: reflexões sobre a plataforma política do governo Temer. Revista de Informação Legislativa: RIL, v. 54, n. 215, p. 139-162, jul./set. 2017.

FERNANDES, Florestan. Capitalismo dependente e classes sociais na América Latina. Rio de Janeiro: Zahar, 1975.

FREITAS, Luiz Carlos de. Educação: dentro do golpe, 2016. Disponível em: $\lfloor$ https://avaliacaoeducacional.com/2016/05/16/educacaogolpe-dentro-do-golpe/> Acesso em: 02 maio 2018.

GOVERNO DEIXA um legado na educação, diz Mendonça, de saída do ministério. Correio do Povo. Notícias. Política. Porto Alegre, 28 mar. 2018. Disponível em: <https://www.correiodopovo.com.br/Noticias/Politica/2018/3/646023/Governo-deixa-um-legado-na-educacao,diz-Mendonca,-de-saida-do-ministerio> Acesso em: 30 mar. 2018.

MATHIAS, Maíra. Uma Política para uma concepção de educação. EPSJV/Fiocruz. Reportagem. 27 out. 2017. Disponível em: 
$<$ http://www.epsjv.fiocruz.br/noticias/reportagem/uma-politica-parauma-concepcao-de-educacao >. Acesso em: 03 maio 2018.

MORENO, Ana Carolina. Cresce o número de jovens entre 15 e 29 anos que não estudam nem trabalham. G1, 18 maio 2018. Disponível em: $\langle$ https://g1.globo.com/educacao/noticia/cresce-o-numero-dejovens-entre-15-e-29-anos-que-nao-estudam-nem-trabalham.ghtml> Acesso em: 24 maio 2018.

OLIVEIRA, Dalila Andrade; DUARTE, Alexandre William Barbosa; CLEMENTINO, Ana Maria. A nova gestão pública no contexto escolar e os dilemas dos(as) diretores(as). RBPAE, v. 33, n. 3, p. 707-726, set./dez. 2017.

PAIVA, Thais. O viés meritocrático da Educação no governo Temer. Carta Capital. Carta Educação. Reportagens, 20 maio 2016. Disponível em: <http://www.cartaeducacao.com.br/reportagens/o-vies-meritocratico-da-educacao-no-governo-temer/> Acesso em: 02 maio 2018.

RODA VIVA. Entrevista com Mendonça Filho, 11 de outubro de 2016. Disponível em: <https://www.youtube.com/watch? ${ }_{v}=5$ OvDejFIt U> Acesso em: 13 maio 2018.

SOUZA, Ângelo Ricardo. Explorando e construindo um conceito de gestão escolar democrática. Educação em Revista, Belo Horizonte, v. 25, n. 03, p. 123-140, dez. 2009. 


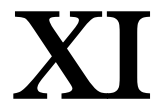

\title{
EDUCAÇÃO INFANTIL EM RISCO: “CADÊ $O$ DIREITO QUE ESTAVA AQUI?! O GOLPE COMEU!"
}

\author{
Marcia Eucia Anacleto Osouza \\ Ana Ruicia Goulart de forria
}

\section{Introduzindo o debate...}

O debate sobre a ameaça que a primeira etapa da educação básica - a Educação Infantil - vivencia desde o marco do impeachment da Presidenta Dilma Roussef, em 2016, aponta a importância da defesa da educação pública e de qualidade para as crianças de 0 a 6 anos no Brasil.

Direito constitucional alcançado pela luta histórica de mulheres, feministas e as militantes sindicais, a Educação Infantil é uma conquista política que garante creches e pré-escolas (art. 208, inciso IV da Constituição Federal de 1988) organizadas por meio de projetos pedagógicos que priorizem o brincar, o movimento, a curiosidade, a imaginação e a expressão infantis, além da convivência entre crianças de mesma idade e idade diferentes; e o respeito, reconhecimento e valorização de suas identidades cultural, racial e religiosa ${ }^{1}$. Assim, o tema da Educação Infantil neste curso ${ }^{2}$ revela a importância da reflexão sobre os riscos que a conjuntura política e social atual representa ao alcance do direito, que define crianças e suas famílias como cidadãos, e qual o real compromisso do Estado com a manutenção da democracia e a busca pela igualdade.

"DOI - 10.29388/978-85-53111-28-2-()-f.153-170

1 Ver BRASIL. Diretrizes Curriculares Nacionais para a Educação Infantil. Brasília: SEB/MEC, 2010.

2 "O Golpe de 2016 e a educação", realizado na FE/Unicamp em 2017. 
Neste ano, indagamos os caminhos que seguimos para consolidar um Estado democrático e de direito, diante do avanço do neoliberalismo e da concepção conservadora de sujeito e sociedade. No âmbito das creches e pré-escolas a realidade revela uma política educacional em âmbito local e nacional que, de um lado, materializa projetos político-pedagógicos que resistem e problematizam as desigualdades sociais, raciais, de gênero, de classe social e etárias e, de outro, enfrenta projetos legislativos e executivos que ampliam a entrada do empresariado na oferta de vagas e na gestão das creches e pré-escolas, e que se pautam em um modelo nuclear de família (pai-mãe-filhos/filhas), recusam a diversidade de gênero e silenciam diante da desigualdade racial.

Paralelamente, constatamos uma avalanche de portarias e emendas constitucionais que materializam a redução da autonomia do Estado na gestão das políticas sociais, ampliando as desigualdades sociais e, no que concerne à Educação Infantil, "comendo" o direito das crianças de 0 a 6 anos a creches e pré-escolas públicas e de qualidade. Pesquisadores e pesquisadoras da pequena infância, assim como representantes de movimentos em defesa da Educação Infantil focados na trajetória de construção dessa política educacional, enfatizariam que algumas perdas já eram sentidas anteriormente, quando as crianças de 6 anos passaram a fazer parte do ensino fundamental (lei ${ }^{\circ}$ 11.274/06), e também com a Emenda Constitucional no ${ }^{\circ}$ 59/09, que definiu a obrigatoriedade da frequência das crianças de 4 e 5 anos na pré-escola.

Mas, se até aquele momento havia a abertura ao diálogo e ao debate sobre a política educacional almejada, de modo que, diferentes Fóruns de Educação Infantil (municipais, estaduais e nacional, como o MIEIB - Movimento Interfóruns de Educação Infantil do Brasil) participavam das definições e buscavam estabelecer um consenso em relação aos rumos da educação da pequena infância brasileira; na conjuntura política e econômica atual, a participação tem sido controlada e cerceada em favor da tendência à efetivação de uma política educacional voltada para alimentar interesses do empresariado na educação.

Tais interesses, como temos visto, concebem a educação numa perspectiva mercadológica e homogênea; reduzindo o plural ao comum e alocando em segundo e terceiro planos as diferenças e diversi- 
dades socioculturais. Concretamente, vivemos sob um cenário de retrocessos políticos que, pautados na perspectiva neoliberal também interessada na política educacional para a Educação Infantil buscam materializar, a partir do lema "nacional", o apagamento das diferenças que caracterizam a história, a formação e a contemporaneidade brasileira, ao encerrar processos democráticos e estratégias políticas de superação de desigualdades que afetam, sobremaneira, nossas crianças negras, indígenas, ribeirinhas, pomeranas, quilombolas e tantas outras. Assim, este texto tem um desdobramento do debate que é refletir acerca da ameaça que o conservadorismo, o patriarcado, o racismo, o adultocentrismo e o neoliberalismo em vigência na sociedade e na política significam no que tange às diferenças, dentre elas, as que dizem respeito às crianças negras e quilombolas.

\section{Educação Infantil: um direito sob ameaça}

A Educação Infantil é um direito definido na Constituição de 1988 pela garantia de creches e pré-escolas às crianças de zero a seis anos, independente de classe social, raça e gênero. É a primeira etapa da educação básica, oferecida em espaços coletivos institucionais na esfera pública e não-domésticos da esfera privada , que concebem as crianças como sujeitos de direitos e protagonistas sociais que constroem entre elas, durante diferentes interações e práticas cotidianas, representações acerca da natureza e da sociedade (BRASIL, 2010) e constroem a realidade social. Enfim, as crianças produzem as culturas infantis.

O alcance do direito à Educação Infantil é fruto de um processo histórico de mobilização de mulheres que, lembrando Chimamanda Ngozi Adichie, "foram encorajadas a se atreverem a mudar o mundo", ao exigir do Estado o compromisso com a educação das crianças em espaços onde pudessem produzir e expressar as culturas infantis por meio da brincadeira, da imaginação e da fantasia, da observação e experimentação. Essa perspectiva de criança e infância como, respectivamente, sujeito e momento da vida caracterizado pela criação, participação e autonomia infantil revelava, à época, um patamar da política educacional que se contrapunha às perspectivas educacionais históri- 
cas que traduziam a creche e a pré-escola como política de assistencialismo e compensação.

O reconhecimento da criança como sujeito de direito também significou uma ruptura com um processo de implantação do atendimento em creches e pré-escolas que, influenciado por agências internacionais atuantes no hemisfério sul durante as décadas de 60 e 70, pautava-se em perspectivas de controle à pobreza. Neste período, a Educação Infantil configurava-se como meio para assegurar, na creche, assistência às crianças pobres e, na pré-escola, a preparação para o ingresso do ensino fundamental (ROSEMBERG, 2003). E, efetivamente, a realidade revelava-se por um atendimento caracterizado pela informalidade das propostas educativas em creches, com foco no cuidado, higiene e alimentação das crianças; e pela transposição de propostas pedagógicas do ensino fundamental às crianças que frequentavam a pré-escola (Idem).

Mas, de acordo com Faria (2005), em meio a esta realidade cresciam as pesquisas interessadas na escuta e observação das crianças, e na compreensão de como os coletivos infantis eram capazes de estabelecer múltiplas relações, comunicando, a seu modo, formas de representar fenômenos e pessoas, papéis sociais e situações vividas, revelando a Educação Infantil como o tempo e o espaço de produção de múltiplas, de "cem linguagens",

No caso da pré-escola (crianças de 4 a 6 anos), o direito à educação significa a criação de espaços, tempos e materiais organizados por adultas e adultos que, comprometidas/os com o conhecimento, articulam as experiências das crianças à amplitude dos conhecimentos em suas dimensões social, cultural, tecnológica, científica. Essas definições sistematizam-se em consonância com os estudos da infância e da criança realizados desde 1970, os quais concluem que:

[...] desde pequenininhas [as crianças] são capazes de estabelecer múltiplas relações, são comunicadoras por excelência, são portadoras de histórias, são, enfim, sujeitos de direitos. Além de imitarem, se conformarem, reinventarem e reproduzirem a cultura de sua época colocada à disposição pela sociedade burguesa, machista, eurocentrista, colonialista, pela sociedade adultocêntrica (como já estudado e constatado com crianças escolares e crianças maiores), também as crianças pequenas (e as grandes!) são curiosas, descobrem, imaginam, inventam, diver- 
tem-se, transgridem, resistem [...] São, portanto, capazes de sofisticadas formas de organização do pensamento e de diversas formas de manifestá-las mesmo antes de ler e escrever com letras” (FARIA, 2011, p. XIV).

Hoje, transcorridas três décadas de pesquisa e reconhecimento das crianças como sujeitos sociais e de direitos, no que tange à Educação Infantil acumulamos um conjunto de orientações para a construção de creches e pré-escolas, e a elaboração de projetos pedagógicos pautados no reconhecimento da agência da criança e na especificidade de sua educação. Acumulamos a luta pela ampliação da oferta de vagas em creches públicas, a efetivação da formação docente, bem como a qualificação de todas as profissionais e todos os profissionais da Educação Infantil, de acordo com as definições da Lei de Diretrizes e Bases da Educação Nacional (BRASIL, 1996³). Além disso, alcançamos o direito das crianças a práticas pedagógicas cujo currículo tenha como eixos as interações e as brincadeiras, e não a antecipação ou compensação para garantir apenas o êxito no ensino fundamental.

Contudo, diante das mudanças político-sociais e institucionais deflagradas nos últimos dois anos, amargamos a ameaça de perspectivas compensatórias (da pobreza e da chamada "aprendizagem”) para as creches e pré-escolas, com o avanço de uma nova roupagem neoliberal para a condução da política educacional, tendo em vista a predominância do setor empresarial na educação. Não que essas perspectivas neoliberais tivessem desaparecido do cenário educacional e, especificamente, da educação das crianças pequenas, mas com a tomada do Estado por um viés político conservador e neoliberal, o mote da política nacional de creches e pré-escolas tem se transformado vorazmente.

Neste sentido, estamos diante da revelação de um "elefante" que estava há décadas entre nós, mesmo pós abertura democrática, aguardando que nós ali ao lado o víssemos, isto é, que as condições sociais e políticas adequadas para aprofundar a desigualdade e a exclusão não pudessem mais ser negligenciadas, já que estão tão implícitas e explícitas quanto ele.

\footnotetext{
${ }^{3}$ Ver BRASIL. Lei no ${ }^{\circ}$ 9394, de 20 de dezembro de 1996. Estabelece as diretrizes da educação nacional. Brasília, 1996.
} 
A partir do enfoque na Educação Infantil, observamos a vigência de um projeto nacional que, após o impeachment, ampliou a redução da autonomia do Estado na educação, e em outras áreas sociais (como saúde e assistência social) importantes para a maioria da população, ou seja, os pobres, os negros, além das populações indígenas, quilombolas e ribeirinhas.

No âmbito das políticas educacionais que hoje ameaçam a qualidade da educação e das experiências das crianças em creches e préescolas, temos a inclusão da Educação Infantil no Pacto Nacional pela Alfabetização na Idade Certa (PNAIC), determinada pela Portaria n ${ }^{\circ}$ 826, de 07 de julho de 2017, e a consolidação de prerrogativas curriculares para a educação das crianças de 0 a 5 anos na Base Nacional Comum Curricular (BNCC), aprovada pela Resolução $\mathrm{CNE} / \mathrm{CP} \mathrm{n}^{\circ} .2$, de 22 de dezembro de 2017.

Tais políticas representam um risco eminente ao direito das crianças a experiências cotidianas em creches e pré-escolas que respeitem o brincar, a curiosidade, a imaginação e a expressão, a individualidade, a diversidade e as identidades, ou seja, direitos que são apontados e sistematizados, desde 1995, no documento Critérios de Atendimento em Creches que respeitem os direitos fundamentais das crianças (CAMPOS e ROSEMBERG, 1995).

Em relação ao PNAIC na Educação Infantil, as análises revelam que pela via de uma política nacional de avaliação (FREITAS, 2014), desde a pré-escola, serão retomadas as perspectivas antecipatórias voltadas à preparação sistemática das crianças de 4 e 5 anos para a aquisição do código da escrita. Vale lembrar que quando foi criado o PNAIC, a Coordenadoria da Educação Infantil do MEC, COEDI e toda militância dos fóruns estaduais e do MIEIB foram contra a participação da educação infantil no programa.

Não sem enfrentamentos, recentemente, o ingresso da Educação Infantil neste Programa que define a "idade certa" para crianças de diferentes contextos sociais e culturais "adquirirem uma competência" eleita como importante numa sociedade desigual; observamos a adesão de vários municípios brasileiros a uma formação unívoca de docentes para implementarem esta política que, em outras palavras, "come" o tempo da infância. Infelizmente, também temos ouvido muitas denúncias de professoras/es que estão sendo impedidas de pra- 
ticar seu direito a "desobediencia civil" e continuar a praticar as orientações trazidas pelas Diretrizes Curriculares. Afinal, qual a "idade certa” para ler e escrever as letras, quando nossas crianças escrevem o mundo com desenhos, garatujas, movimentos, rodopios, silêncios, choros, risadas, e as muitas experiências vividas no faz-de-conta?

Na contramão dessas políticas que ameaçam reduzir a infância e excluir suas pluralidades, defendemos, assim como pedagogas/os e sociólogas/os da infância, o direito das crianças a espaços coletivos que respeitem suas múltiplas linguagens, onde brincadeiras e interações propositivas e instigantes sejam prioridades na organização pedagógica. E, neste sentido, em contraposição à políticas de "idade certa" e de formação unívoca destituída de diferença e diversidade, concebemos que a Educação Infantil envolve a ampliação de saberes e conhecimentos pelas crianças em tempos complexos, múltiplos, de recriação e ressignificação, de faz-de-conta e imaginação. As crianças são sujeitos que se movimentam, cantam, pintam, desenham e conhecem o mundo enquanto vivem suas experiências nele, e são essas produções que devem ser valorizadas e estão inscritas em nossas Diretrizes Curriculares para a Educação Infantil Nacional.

As crianças são sujeitos sociais de diferentes culturas, origens étnicas e raciais. São crianças negras vivendo em diferentes regiões brasileiras, em grandes e pequenas cidades (MORETTI, 2009, SANTIAGO, 2014). São crianças quilombolas, ribeirinhas, pomeranas, sem-terrinhas, indígenas, imigrantes, que nos revelam diferentes experiências históricas, étnicas e territoriais (ROSSETTO, 2009, RAUTA SILLER, 2011, SOUZA, 2015). Por isso, a política de Educação Infantil que se produz em cada território é constituída pelo conjunto de todas as outras facetas do social em relação, ou seja, pelas questões históricas, econômicas, raciais, étnicas, territoriais. Além disso, são infâncias perpassadas pelas questões de gênero, o lugar das mulheres na sociedade e as questões etárias, o que nos leva a pensar o significado de políticas de âmbito nacional, que relegam a diversidade para segundo plano e, consequentemente, acarretam no aprofundamento das desigualdades e na reafirmação de uma perspectiva monocultural e adultocêntrica de educação para uma criança no singular voltada para o "vir a ser" adulto trabalhador numa sociedade capitalista, conservadora, misógina, homofóbica e racista. 
Mas, este debate não se encerra com o PNAIC na Educação Infantil, pois em paralelo há esforços governamentais na condução de uma política de educação focada na implementação da Base Nacional Comum Curricular (BNCC) que, aprovada em fins do ano passado, representa um movimento que se quis orgânico em 2015, mas foi tomado de assalto em meio às mudanças transcorridas em 2016.

O texto final da BNCC, fruto de três versões e muitas mudanças na participação das organizações representativas do cenário educacional brasileiro, traduz uma ameaça ao direito das crianças à educação pública, de qualidade e socialmente referenciada, na medida em que, sistematiza-se a partir de perspectivas empresariais e homogeneizantes.

O Movimento Todos pela Educação e agora Todos pela Base define o viés mercadológico com o qual a educação nacional e, nela, a Educação Infantil, vem sendo projetada. Formado por representantes de conglomerados empresariais que se voltam para a educação brasileira há mais de uma década, este movimento fortaleceu-se com o processo do impeachment, de tal forma que, paulatinamente, ganhou espaço na condução das definições acerca do currículo nacional. Este currículo, definido como "comum" num país da diversidade cultural e da desigualdade social, define metas e competências a serem alcançadas na educação de nossas crianças, desde bebês, e, por conseguinte, sob a mesma lógica empresarial que influencia o documento, subentende processos de avaliação do alcance de metas, a despeito da processualidade do cotidiano de cada creche e pré-escola e das experiências de cada contexto social e cultural.

Importante ressaltar o aspecto homogeneizante que sustenta a BNCC, e que remete à Educação Infantil como uma política sob ameaça.

Quando nos deparamos com o texto final da BNCC, constatamos que é ainda mais generalizante e, ao mesmo tempo, monocultural no que tange às questões referentes à diversidade e às desigualdades que emergem no cotidiano das escolas e que precisam compor os currículos e projetos pedagógicos. No que tange às questões étnico-raciais na educação, tema tão desafiador à sociedade brasileira, e sob o qual o movimento negro, intelectuais e pesquisadoras/es têm se debruçado ao longo de décadas, o documento produz um silêncio que representa 
um retrocesso à política educacional que vinha se configurando nos últimos doze anos.

Mesmo diante de quinze anos da definição da temática étnicoracial como um dos patamares para pensar igualdade e equidade no currículo da educação nacional, um documento definido como nacional não dá a importância ao reconhecimento e valorização da trajetória de negros e africanos na sociedade brasileira. Ao contrário, a BNCC é avessa às questões decorrentes da história do Brasil em relação à população negra e indígena, que são mencionadas em notas de rodapé e citações introdutórias do documento, sem menção a conteúdos, temas ou propostas pedagógicas que envolvam a trajetória da população negra no Brasil, os processos de luta e resistência à escravidão e à desigualdade racial, a importância de conhecer e valorizar a história e a cultura africana. Esta ausência está em todo o documento da BNCC, e não apenas na Educação Infantil, é um alerta para entendermos a sociedade que está no momento sendo projetada após termos alcançado um conjunto de políticas sociais, dentre elas, educacionais, que visavam a igualdade almejada a partir do reconhecimento, da valorização e do respeito à história e presença do negro e sua cultura em nossa sociedade. Afinal, em que medida silenciar a população negra e o continente africano de um currículo nacional está a nos dizer do silenciamento das demais diferenças que traduzem desigualdades etárias, de gênero, étnicas e de classe social no Brasil?

\section{Um direito sob ameaça e muitas crianças em risco: reflexões so- bre a temática étnico-racial}

O olhar para as crianças negras, que como aponta Abramowicz e Oliveira (2011), são crianças e negras, é um caminho para indagarmos e compreendermos o significado da ameaça ao direito à Educação Infantil pública e de qualidade para todas as crianças brasileiras na atualidade.

No que se refere ao direito à educação, historicamente, as crianças negras estiveram fora das escolas ou nelas viveram as primeiras experiências de preconceito racial e de representações sociais negativas sobre seus corpos e grupos de origem. Diante dessa realidade, ao longo de todo o século XX o movimento negro tem elaborado estraté- 
gias políticas e pressionado o Estado para alcançar e melhorar a qualidade da educação, considerando a valorização do negro e a construção de relações étnico-raciais afirmativas. Desse modo, transformar a escola que reproduz estereótipos negativos sobre a população negra tem sido uma luta desde o pós-Abolição (GONÇALVES e GOLÇALVES E SILVA, 2000).

Com a Constituição Federal de 1988, o Estado abriu o diálogo com o movimento negro e reconheceu não só o racismo brasileiro, como também instaurou canais de debate e proposição da educação que valorizasse a diversidade étnico-racial, o que resultou em um conjunto de ações concomitantes em estados e municípios. Entre a última década do século XX e o início dos anos 2000, cidades alteraram legislações orgânicas e diretrizes para que as escolas abordassem a cultura e a história do negro e do continente africano nos currículos, a fim de promover a igualdade racial em termos de ampliação do conhecimento e abertura ao debate sobre o racismo em nossa sociedade.

Em âmbito nacional, em 2003 foi alterado o Artigo 26 da Lei de Diretrizes e Bases da Educação Nacional, definindo a obrigatoriedade do trabalho com a temática do negro e da África, e das relações étnico-raciais no cotidiano e nos currículos das escolas ${ }^{4}$. No ano seguinte, foram aprovadas as Diretrizes Curriculares Nacionais para a Educação das Relações Étnico-Raciais e o Ensino de História e Cultura Afro-Brasileira e Africana em toda a Educação Básica e Ensino Superior ${ }^{5}$.

A política educacional que se instaurou a partir dessas legislações criou um movimento nacional no qual se envolveram universidades, professoras e professores, pesquisadoras e pesquisadores da temática étnico-racial, gestores e gestoras de secretarias municipais de educação e de escolas, desde a Educação Infantil, em ações de ampliação de repertórios de valorização da cultura negra e africana, e de formação para a compreensão dos aspectos inerentes às relações étnico-

\footnotetext{
${ }^{4}$ Ver BRASIL. Lei no ${ }^{\circ}$ 10.639/03, de 9 de janeiro de 2003. Altera a Lei no 9.394 , de 20 de dezembro de 1996, que estabelece as diretrizes e bases da educação nacional, para incluir no currículo oficial da Rede de Ensino a obrigatoriedade da temática "História e Cultura AfroBrasileira”, e dá outras providências. Brasília, 2003.

${ }^{5}$ Ver BRASIL. Diretrizes Curriculares Nacionais para a Educação das Relações Étnico-Raciais e para o Ensino de História e Cultura Afro-Brasileira e Africana. Brasília: MEC/SEPPIR, 2004 .
} 
raciais, tais como: as desigualdades raciais, o racismo, o preconceito e discriminação racial, a representação estereotipada do continente africano.

A efetivação dessa legislação pauta-se em três princípios explicitados nas Diretrizes: (1) consciência política e histórica da diversidade; (2) fortalecimento de identidades e de direitos e (3) ações educativas de combate ao racismo e discriminações. Em 2016, a implementação da política ocorria na articulação entre diferentes ministérios e secretarias nacionais, como a Secretaria Especial de Políticas de Promoção da Igualdade Racial (SEPPIR), a Fundação Cultural Palmares (FCP - Ministério da Cultura) e o Ministério da Educação, através da Secretaria de Educação Continuada, Alfabetização, Diversidade e Inclusão (SECADI), com orçamento que ainda demandava aumento, quando foi interrompida pelos processos políticos e jurídicos decorrentes do impeachment.

Sabemos que o movimento de implementação de mudanças curriculares, principalmente, numa temática de grande resistência nas escolas, demanda esforços no sentido de produção de estudos, pesquisas, elaboração de novos conteúdos e propostas pedagógicas com o envolvimento de todos os sujeitos da educação, desde a Educação Infantil.

Além disso, modificar currículos requer que a escola seja repensada como lugar do encontro entre diferentes e educação de diferentes em relação, e não um espaço de transmissão de conteúdos neutros por professoras ou professores "neutros". Exige pensar as escolas, e em nosso caso, creches e pré-escolas, como lugares da pluralidade de ideias acerca das coisas e das pessoas, e que estas ideias podem orientar formas de ver o diferente, como a população negra, enquanto sujeitos que protagonizam (ou não) a realidade social e histórica brasileira (SOUZA, 2018).

Para alcançar tais mudanças na educação, desde a lei 10.639/03 estabeleceu-se o diálogo com o Ministério da Educação para que viabilizasse formação continuada e formação inicial, que contemplassem o estudo da trajetória do negro, o debate sobre o racismo, a discriminação racial e o preconceito, o significado da desigualdade racial no país. A implementação da legislação que visa à igualdade racial, definida nas Diretrizes Curriculares Nacionais para a Educação 
das Relações Étnico-Raciais, História e Cultura Afro-Brasileira e Africana, pressupôs, desde os seus primórdios, que a escola não estava preparada para lidar com a diferença, e que a formação de seus profissionais era uma política educacional necessária. Segundo as Diretrizes, os sistemas de ensino e estabelecimentos de educação básica, desde a Educação Infantil, precisarão providenciar, dentre outros:

Introdução, nos cursos de formação de professores e de outros profissionais da educação: de análises das relações sociais e raciais no Brasil; de conceitos e de suas bases teóricas, tais como: racismo, discriminações, intolerância, preconceito, estereótipo, raça, etnia, cultura, classe social, diversidade, diferença; de práticas pedagógicas, de materiais e de textos na perspectiva da reeducação das relações étnico-raciais [...] da História e Cultura dos Afro-brasileiros e dos africanos (BRASIL, 2004, p. 23).

Imerso nesse movimento de reformulação dos projetos pedagógicos da Educação Infantil, visando à superação das desigualdades raciais, propostas de mudanças curriculares ingressaram nos documentos das Diretrizes Curriculares da Educação Infantil - DCNEI, definindo que a proposta pedagógica deve garantir a construção de:

[...] novas formas de sociabilidade e de subjetividade comprometidas com a ludicidade, a democracia, a sustentabilidade do planeta e com o rompimento de relações de dominação etária, socioeconômica, étnico-racial, de gênero, regional, linguística e religiosa (BRASIL, 2010, p. 17).

O texto das DCNEI também é contundente ao afirmar que a proposta pedagógica deve se assentar no reconhecimento, valorização, respeito e interação das crianças com o patrimônio histórico e cultural afro-brasileiro e africano, além de combater a discriminação e o racismo (Idem). Assim, entendemos que a Educação Infantil, enquanto direito de todas as crianças, transforma-se em espaço de luta antirracista ao garantir o acesso das crianças negras, e a sua permanência por meio da garantia à qualidade presente em um projeto pedagógico que reconhece, respeita e valoriza as diferenças.

Mas, diante da conjuntura política atual, o que temos visto é o silenciamento do Ministério da Educação em relação à política de formação docente para a educação das relações étnico-raciais, uma das principais frentes de execução da luta antirracista na Educação Infan- 
til. Assim, se até então já eram escassos os recursos públicos para formação docente para a superação da desigualdade racial nas escolas, no contexto atual observamos um retrocesso.

Paralelamente, no contexto político nacional atual, as crianças e suas diferenças manifestas na condição racial, de gênero e na composição familiar estão sob forte ameaça de uma perspectiva de planejamento educacional que se afirma inovadora, mas aloca a diversidade na transversalidade, em consonância ao avanço de perspectivas conservadoras, patriarcais, racistas e homofóbicas presentes no bojo social.

Já, no que tange aos documentos referentes à $\mathrm{BNCC}$, como o texto final e o parecer, sem olharmos para os embates políticos em torno deles, temos o problema da alocação transversal e pontual da diversidade. O Parecer afirma que os temas raça, etnia, gênero, direitos humanos, cultura negra e indígena, denominados novamente como transversais, sejam incluídos de maneira integrada às disciplinas e áreas de conhecimento. No entanto, no texto da Base aparecem de maneira vaga, sem o devido detalhamento de sua importância, apontando apenas habilidades que crianças e adolescentes devem ter ao final de cada ano do ensino, como se abordar a temática racial ou africana, por exemplo, fosse apenas transmitir um conjunto de prescrições ou observar e avaliar comportamentos (SOUZA, 2017).

Só para assinalar um aspecto estruturante da BNCC, seus fundamentos pedagógicos (concepções de educação) têm como foco o desenvolvimento de dez competências que as crianças, desde a Educação Infantil, devem alcançar ao longo de sua trajetória na Educação Básica: conhecimento, pensamento científico, crítico e criativo, repertório cultural, comunicação, cultura digital, trabalho e projeto de vida, argumentação, autoconhecimento e autocuidado, empatia e cooperação, responsabilidade e cidadania. Ao concentrarmos a análise na competência intitulada "repertório cultural", verificamos que se espera das crianças a existência de níveis de "senso de identidade individual e cultural", e de "curiosidade, abertura e acolhimento a diferentes culturas e visões de mundo”. O quadro referente a esta competência não nos diz da Educação Infantil, especificamente, mas revela o quão arriscado é avaliar "competências” em crianças de oito anos, pois apontam, 
numa mesma lógica do PNAIC na Educação Infantil, expectativas de aquisição de competências nas creches e pré-escolas.

Ao mesmo tempo, notemos como o alcance dessa competência está ligada a uma avaliação do comportamento da criança, e indaguemos sobre qual a possibilidade de fazê-la num contexto em que a própria instituição de Educação Infantil revela dificuldades em compreender as diferenças e o significado das diversidades?

Numa sociedade que ainda não superou profundas desigualdades pautadas nos marcadores raciais, falar em competências que encaminham processos de avaliação de comportamentos e exigem a subjetividade ainda preconceituosa e homogeneizante de professores e professoras, desde a Educação Infantil, equivale ao aprofundamento da exclusão de crianças negras.

Uma política educacional que antecipa processos classificatórios na Educação Infantil sinaliza processos que definem, desde o berçário, trajetórias infantis, a exemplo do que revela Santiago (2014) ao nos contar sobre a menina negra de dois anos que se percebe como diferente e inferior em relação às crianças brancas porque traz em seu corpo a negritude. A fala da menina, que diz como seu cabelo é representado como feio e ruim, revela como a criança é sujeito que constata a diferença enquanto desigualdade e exclusão, num contexto educativo que se diz neutro em relação às relações étnico-raciais. Esta neutralidade, longe de produzir a igualdade, revela a reprodução de preconceito e desigualdade racial, a afirmação da estética corporal branca e a negação do corpo negro.

A BNCC se quer "base" e "comum" para todo o território brasileiro. Porém, afeita às categorias negro, indígena, quilombo e quilombola, afro-brasileiro, África, raça e etnia. A ausência da perspectiva racial em um documento de amplitude nacional, num país historicamente alicerçado na escravidão do negro, na produção de estereótipos negativos para o corpo e a cultura negra, e na manutenção das desigualdades sociais por meio do racismo, revela, outrossim, intencionalidades que almejam apagar do debate educacional a superação de relações étnico-raciais que alocam a população negra na subalternidade.

Mas, o ocultamento da desigualdade racial enquanto discurso e conhecimento sob o qual a educação deve se debruçar, desde a creche, coaduna com o acirramento das desigualdades sociais a que nos 
leva a atual conjuntura política e social brasileira. Por isso, ao falar da Educação Infantil em risco, estamos diante de uma política educacional que se volta para a formação de um cidadão específico, capaz de reunir, ao final de sua trajetória escolar, apenas três competências: ler e escrever, realizar as quatro operações matemáticas e compreender a lógica formal simples.-

O foco na aquisição de competências, princípio da BNCC, alinhado à entrada da "idade certa" para as crianças de 4 e 5 anos nos coloca sob alerta. Competências para qual trabalhador e para qual criança. Esta criança tem idade, raça, etnia, gênero, classe social? $\mathrm{O}$ que a nossa sociedade nos diz?

Podemos inferir que a definição de uma trajetória das crianças negras, das meninas, das crianças transgêneros, crianças oriundas de casais homoafetivos ou pertencentes a outras infâncias, como as crianças quilombolas e indígenas, esteja "pré-definida" numa política avessa a essas questões. Podemos inferir com um certo nível de certeza que, numa sociedade onde avança o conservadorismo das elites - atrelado ao poder dos latifundiários, das empresas multinacionais e dos industriais que concentram a riqueza nacional -, e na qual ganha espaço de governança projetos de base machista, misógino e racista, a diversidade das infâncias esteja sob ameaça.

Neste sentido, estamos sob a vigência de políticas educacionais que produzem, desde a creche, estratégias de controle a partir da reprodução de desigualdades, dentre elas, a racial, que aliada às desigualdades de gênero, à perseguição às diferentes realidades familiares, à formulação de projetos como Escola Sem Partido, buscam ampliar o fosso social que separa ricos e pobres, negros e brancos.

\section{Para encerrar um debate em construção: e as infâncias invisíveis?}

Abordamos neste texto o significado das mudanças decorridas pós-impeachment da presidenta Dilma Roussef, no que concerne à política de Educação Infantil e à questão étnico-racial. Ponderando sobre a aprovação da BNCC e do PNAIC na Educação Infantil, consideradas políticas que ameaçam o direito à educação pública e de qualidade para as crianças de zero a seis anos tendo em vista o enfoque na aquisição de conteúdos (ler, escrever) e competências voltadas para 
preparar os sujeitos ao trabalho numa sociedade capitalista e neoliberal, analisamos como a questão étnico-racial se apresenta e revela perspectivas homogeneizantes que contribuem para a manutenção da desigualdade racial.

Mas, considerando a realidade étnico-racial brasileira, indagamos acerca de outras infâncias, como a bilíngue pomerana (RAUTA SILLER, 2011) e a negra quilombola (SOUZA, 2015). Afinal, como as crianças quilombolas são afetadas pela conjuntura política e social atual?

Em pesquisa realizada por Souza (2015), a realidade das comunidades quilombolas revela-se em estreita relação com as mudanças na estrutura social. Assim, no que diz respeito às políticas sociais para os quilombos, alcançadas ao longo dos anos 2003 e 2016, verificamos um retrocesso no que se refere ao encaminhamento de reconhecimento da propriedade da terra onde historicamente vivem, e na efetivação da educação diferenciada expressa nas Diretrizes Curriculares Nacionais para a Educação Escolar Quilombola (Resolução $\mathrm{CEB} / \mathrm{CNE} \mathrm{n}^{\circ}$ 8, de 20 de novembro de 2012).

As comunidades quilombolas ocupam terras, em grande parte, sob litígio e disputa com representantes de interesses econômicos agrários, turísticos, imobiliários, e com o próprio Estado. Porém, mesmo diante de sua presença histórica, o reconhecimento e a propriedade definitiva da terra, garantida pela Constituição Federal, não tem sido efetivados. Ao contrário, com a nova conjuntura política, as pastas ministeriais e secretarias responsáveis pelo encaminhamento das ações ${ }^{6}$ dessas comunidades foram esvaziadas ou alocadas em outras, disputando prioridades numa estrutura de governo que prioriza os interesses da elite agrária e dos industriais.

Em relação à educação, as definições legais para a escola quilombola, desde a Educação Infantil, mantém-se longe da implementação, principalmente, diante das determinações da BNCC. Neste sentido, não há efetivação de um currículo de acordo com as especificidades das comunidades, mas chegam às suas porteiras e fronteiras a educação comum preconizada pelo documento nacional.

${ }^{6}$ Fundação Cultural Palmares e Secretaria de Políticas de Igualdade Racial. 
Essa é apenas uma das realidades infantis sob as quais nos debruçamos enquanto procuramos compreender os efeitos da nova conjuntura nacional na condução da política educacional. Uma infância invisível, assim como a de crianças indígenas, pomeranas, sem-terrinhas e ribeirinhas, de crianças moradoras dos sertões nordestinos, do vale do Jequitinhonha, da região amazônica e tantas outras além das fronteiras brasileiras, de crianças imigrantes, muitas delas venezuelanas e haitianas, e de crianças em exílio, que em meio às famílias vivem os efeitos de processos globalizantes e neocolonialistas que colocam sob risco suas experiências no Brasil e no mundo.

\section{REFERÊNCIAS}

ABRAMOWICZ, Anete, OLIVEIRA, Fabiana de. As relações étnico-raciais e a sociologia da infância no Brasil. IN: BENTO, Maria Aparecida S. (org.). Educação infantil, igualdade racial e diversidade: aspectos políticos, jurídicos e conceituais. SP: CEERT, 2011, p. 47-64. CAMPOS, Maria M., ROSEMBERG, Fulvia. Critérios para um atendimento em creches e pré-escolas que respeite os direitos fundamentais das crianças. Brasília: MEC, SEB, 1995.

FARIA, Ana Lúcia G. de. Apresentação. IN: GEPEDISC - Culturas Infantis. Culturas Infantis em creches e pré-escolas: estágio e pesquisa. Campinas, SP: Autores Associados, 2011.

. Políticas de regulação, pesquisa e pedagogia na Educação Infantil, primeira etapa da educação básica. Educação \& Sociedade. Campinas, SP, vol. 26, nº. 92, p. 1013-1038, out. 2005.

FREITAS, Luiz C. Os reformadores empresariais da educação e a disputa pelo controle do processo pedagógico na escola. Educação \& Sociedade. Campinas, v. 35, nº. 129, p. 1085-1114, out./dez. 2014. GONÇALVES, Luiz A. O., GOLÇALVES E SILVA, Petronilha B. Movimento negro e educação. Revista Brasileira de Educação. RJ, nº . 15, p. 134-158, set./dez. 2000.

MALAGUZZI, Loris. Ao contrário as cem existem. Bambini. Bergamo, ano X, n.2, 1994. (tradução livre do italiano: Ana Lúcia Goulart de Faria, Maira Carmem Silveira Barbosa e Patrizia Piozzi) 
MORETTI, Nara M. As relações raciais na educação infantil: as brincadeiras entre crianças brancas e negras na creche. Trabalho (Conclusão de Curso), Campinas: SP, FE/UNICAMP, 2009.

RAUTA SILLER, Rosali. Infância, educação infantil, migrações. Tese (Doutorado em Educação), Campinas: SP, FE/UNICAMP, 2011.

ROSEMBERG, Fulvia. Sísifo e a educação infantil brasileira. ProPosições, Campinas, n. 40, p. 177-198, 2003.

ROSSETTO, Edna R. A. Essa ciranda não é minha só, ela é de todos nós: a educação das crianças sem terrinha no MST. Dissertação (Mestrado em Educação), Campinas: SP, FE/UNICAMP, 2009.

SANTIAGO, Flávio. "O meu cabelo é assim... igualzinho o da bruxa, todo armado": hierarquização e racialização das crianças pequenininhas negras na Educação Infantil. Dissertação. (Mestrado em Educação), FE/UNICAMP, 2014.

SOUZA, Márcia L. A. Por uma educação antirracista desde a creche!. IN: TELES, Maria Amélia de A., SANTIAGO, Flávio, FARIA, Ana Lúcia G. de. Por que a creche é uma luta das mulheres? Inquietações feministas já demonstram que as crianças pequenas são de responsabilidade de toda a sociedade! São Carlos: Editora Pedro \& João, 2018, p. 91-116.

- Quais as crianças da base nacional comum curricular? Um olhar para as "culturas" sem diversidade cultural. Debates em Educação. Maceió, vol. 8, nº. 16, p. 136-156, jul/dez/ 2016.

. "Ser quilombola": identidade, território e educação na cultura infantil. 2015. Tese (Doutorado em Educação). Campinas: SP, FE/UNICAMP, 2015. 


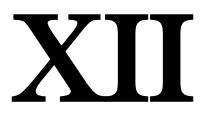

\title{
MICROPOLÍTICAS DAS IMAGENS E SONS DO GOLPE - APONTAMENTOS A PARTIR DO FILME “O PROCESSO", DE MARIA AUGUSTA RAMOS"
}

\author{
Parlos E funardo Albuquerque Chiranda \\ Dpenceslao Chachado de Eliveira OHnior
}

O Todo-ouvidos empenha-se em não olhar.

Em compensação, escuta melhor do que ninguém.

Vem, para, coa-se despercebidamente num canto,

contempla um livro ou uma vitrina,

ouve o que há que ouvir, e imperturbável, alheado, afasta-se.

Poderíamos pensar que nem tenha estado presente,

porque se vale muito bem da técnica de sumir.

[...]

Conhece todos os locais onde exista algo que mereça ser escutado.

Registra tudo e não esquece nada.

Elias Canetti

\section{Preâmbulos}

\subsection{Sobre a aula e seus materiais}

Iniciamos dizendo que resolvemos brincar um pouco porque tudo tem sido bastante difícil nos dois últimos anos. Nos parece que brincar um pouco, neste processo de aproximação com o filme, nos ajuda seguir pensando em estratégias de resistência ao golpe. Uma das

*DOI - 10.29388/978-85-53111-28-2-()-f.171-188 
brincadeiras que fizemos para compor essa fala ${ }^{1}$ foi encontrar textos literários onde aparecem personagens que nos pareceram atuar no filme. Uma atuação certamente diferente dos personagens humanos que atuam nele e que aparecem para nós em imagens e sons. Estes outros personagens - literários - atuam no filme como forças inumanas, como pistas para entrarmos no filme e ao mesmo tempo como linhas de fuga para escaparmos das armadilhas dele. O primeiro destes personagens está presente na epígrafe desse texto ${ }^{2}$. Outros serão trazidos a ele mais adiante.

Outra brincadeira foi construirmos essa aula como um jogral entre nós dois, o qual optamos por fazer desaparecer no texto escrito.

Por fim, uma terceira brincadeira foi fazermos aqui o que não fazemos habitualmente, uma vez que estamos mais acostumados a trabalhar com as imagens e sons do que com explicações e atribuição de sentidos aos filmes e a outras obras audiovisuais. Preferimos pensar em como as imagens nos afetam. Mas tendo em vista a especificidade desta aula faremos algumas interpretações e atribuições de sentido a certas imagens e sons (bem como a certas ausências de imagens e sons) para demonstrar que este filme toma partido em relação aos acontecimentos de 2016 e que podemos atribuir alguns sentidos que talvez tenham escapado aos expectadores que buscam neste filme apenas uma compreensão ou interpretação visual do processo de impeachment.

Cabe dizer que inicialmente convidamos a diretora do filme, Maria Augusta Ramos, para estar aqui hoje conosco, para conversar sobre o seu filme, mas não foi possível, uma vez que ela não estaria no Brasil neste período, pois está acompanhando o filme no exterior, estando ele ainda no circuito dos festivais. Ao mesmo tempo, no entanto, o filme já havia sido lançado nas janelas comerciais das salas de cinema desde o dia 7 de maio. O que conseguimos, por sugestão da Leonara, responsável pela distribuição do filme, foi o lançamento em Campinas uma semana depois de sua estreia nacional. Além disso, a

\footnotetext{
${ }^{1}$ Texto escrito a partir da transcrição das falas dos dois autores na aula ocorrida no dia 21 de junho de 2018. Algumas marcas dessa origem oral restaram no texto, como repetições e redundâncias que reforçam certos argumentos. A aula foi gravada e encontra-se disponível no link https://www.voutube.com/watch? ${ }_{\mathrm{v}}=\mathrm{fdRUpHefd} 8 \mathrm{w}$

${ }^{2} \mathrm{O}$ Todo-ouvidos é um dos 50 personagens que compõem o livro "O Todo-ouvidos - cinquenta caracteres”, de Elias Canetti.
} 
proposta inicial de passar o filme nesta aula encontrou dois problemas que nos levaram a optar por outra forma de trazer as imagens para essa conversa. O primeiro é que o filme não foi lançando em DVD e, por isso, as imagens da internet que tínhamos do filme eram imagens feitas em sessões de exibição no cinema, de pouca qualidade para ser exibida para uma plateia. $\mathrm{O}$ segundo problema é que o filme tem mais de duas horas de duração, o que inviabilizaria a exibição do filme com tempo para debate dentro do horário da aula. Optamos então por trazer, para mobilizar essa conversa, somente o teaser ${ }^{3}$ e o trailer ${ }^{4}$ do filme. O primeiro é uma chamada mais impactante de divulgação do filme, mas que contém muitas informações sobre a produção e o lançamento dele; o segundo é uma peça publicitária de chamada do espectador para ir ao cinema ${ }^{5}$.

\subsection{Sobre o filme e sua diretora}

Talvez seja importante dizer que o filme "O Processo" foi ovacionado no Festival de Berlim e ganhou o prêmio de melhor filme documentário no Festival de Madrid, ambos em 2018.

Para quem não assistiu ao filme é importante dizer que a equipe de Maria Augusta Ramos fez a captação das imagens e sons ao mesmo tempo em que estava ocorrendo o processo de impeachment, depois que ele foi aprovado na Câmera dos Deputados e foi encaminhado ao Senado Federal. A captação das imagens e sons do filme foi feita, portanto, no calor do momento em que estávamos tendo um espetáculo midiático sobre e para o golpe. Ou seja, no mesmo período do ano de 2016 em que estávamos tendo acesso às outras gravações veiculadas por reportagens e matérias de jornais, telejornais, rádio e redes sociais. As datas que aparecem ao longo do filme reafirmam essa sincronicidade entre as cenas filmadas para o filme e a história re-

\footnotetext{
${ }^{3}$ Disponível no link: $\left\langle\right.$ https://www.youtube.com/watch? ${ }_{\mathrm{v}}=\mathrm{O} \operatorname{coSy} 2 \mathrm{KVg} 4 \mathrm{~s}$ >

${ }^{4}$ Disponível no link: 〈https://www.youtube.com/watch? $\left.{ }_{\mathrm{v}}=\mathrm{Z}_{3 \mathrm{rHUGdOXUs}}\right\rangle$

${ }^{5}$ Nesse momento da aula, antes de mostrar as imagens e sons do teaser e do trailer, perguntamos aos presentes quantos tinham assistido ao filme. Somente cerca de um quarto das pessoas o havia assistido no cinema. Prevendo isso, foi que pensamos em fazer uma exposição tanto para quem assistiu ao filme como para quem não o havia assistido, mostrando algumas imagens dele: teaser e trailer num primeiro momento e frames de alguns personagens mais ao final de nossa fala sobre o filme.
} 
cente das imagens e sons que preencheram olhos e ouvidos brasileiros.

Maria Augusta Ramos é uma diretora que vem trabalhando com as instituições judiciais do Estado há algum tempo. Este é o terceiro filme que ela faz neste âmbito; os outros foram Justiça (2004) e Juízo (2008). No caso do filme "O Processo" ela se aproximou da esfera do poder legislativo, acompanhando uma instância do Estado distinta das que havia acompanhado nos dois filmes anteriores. Apesar disso, Maria Augusta não se considera uma diretora militante.

\subsection{Sobre o foco na micropolítica}

Entendemos que nossa contribuição mais significativa para esse curso seria lidar na esfera do que chamamos de micropolítica ou dos processos de subjetivação, uma vez que essa esfera é onde entendemos que as imagens e sons audiovisuais atuam de maneira mais contundente na nossa sociedade.

Se o golpe impetrado nas esferas macropolíticas se deu como lei, as imagens e sons deram efetividade a ele nas esferas das micropolíticas de subjetivação e realizaram golpes seguidos de golpes, verdadeiros socos no estômago, tapas na cara, chutes na bunda, coronhadas na cabeça. Tudo isso através de olhos e ouvidos de corpos sentados diante da tevê ou da tela de um computador. Muitos de nós sentimos essas sensações descritas acima, sem que qualquer corpo nos socasse, estapeasse, chutasse ou desse coronhadas. Assim são as imagens e sons audiovisuais: presentificam não somente informações, mas sensações... e essas últimas se enraízam mais fundo nos corpos, buscam nossas entranhas e lá se instalam, como incômodos e desassossegos que não fazemos ideia de onde vêm. São aquilo que Suely Rolnik chama de ovos-de-tempo ${ }^{6}$ : aquelas coisas que nos afetam e que, apesar de ainda não se fazerem sensíveis em nós, já pressionam a vida, estão em nossos corpos mas ainda não foram propriamente incorporadas, não compõem nossa subjetividade.

$\mathrm{O}$ que esse curso vem realizando tem sido, a nosso ver, - através das palavras e pensamentos de outros que estiveram aqui, e, hoje, através das imagens e sons - mobilizar essas entranhas de modo a mo-

${ }^{6}$ Ver "Pensamento, corpo e devir". Núcleo de Subjetividade. Disponível em: http://www4.pucsp.br/nucleodesubjetividade/Textos/SUELY/pensamentocorpodevir.pdf 
ver esses ovos-de-tempo para fazer deles matéria-prima subjetiva, parte do corpo que age e não somente sofre os efeitos das sensações nele entranhadas.

$\mathrm{Ou}$, dito de outra maneira, nas palavras de Milton José de Almeida, estamos aqui tentando expiar e espiar: expiar culpas e espiar coisas, através desse filme que expressa em imagens e sons o conteúdo social e político mobilizado nesse curso.

Trazemos aqui algumas considerações que nos fazem pensar o golpe a partir do plano da micropolítica que esse conteúdo social - o golpe - colocou em circulação e os possíveis efeitos de suas imagens e sons em nossas subjetividades.

\section{Entrando no golpe através das imagens e sons filmicos}

\subsection{A ambiência do poder e o absurdo do processo}

Num primeiro momento seria interessante pensar por que o filme se chama "O Processo". Quem assistiu ao filme sabe que, em determinado momento, Lindbergh Farias diz que aquele processo parecia com o do livro "O Processo" de Franz Kafka. Mais a frente no texto, traremos o personagem $\mathrm{K}$, do romance kafkiano, para nossa conversa com o filme. Nesse momento, trazemos a ela um outro personagem, o líder, nas palavras de Clarice Lispector ${ }^{7}$, como mais uma jogada de nossa (séria e interessada) brincadeira literária.

O sono do líder é agitado. A mulher sacode-o até acordá-lo do pesadelo. Estremunhado, ele se levanta, bebe um gole de água. Diante do espelho refaz uma expressão de homem de meia-idade, alisa os cabelos das têmporas, volta a se deitar. Adormece e a agitação recomeça. "Não, não" debate-se ele com a garganta seca.

O líder se assusta enquanto dorme. O povo ameaça o líder? Não, pois se líder é aquele que guia o povo exatamente porque aderiu ao povo. $\mathrm{O}$ povo ameaça o líder? Não, pois se o povo escolheu o líder. O povo ameaça o líder? Não, pois o lidar cuida do povo. O povo ameaça o líder?

\footnotetext{
7"O líder" é o título de um dos pequenos textos que compõem o livro "Para não esquecer", de Clarice Lispector.
} 
Sim, o povo ameaça o líder do povo. O líder revolve-se na cama. De noite ele tem medo. Mas o pesadelo é um pesadelo sem história. De noite, de olhos fechados, vê caras quietas, uma cara atrás da outra. E nenhuma expressão nas caras. É só este o pesadelo, apenas isso.

$[\ldots]$

De noite é sempre maior o número silencioso. Cada noite as caras aproximam-se um pouco mais. Cada noite ainda um pouco mais. Até que ele já lhes sente o calor do hálito. As caras inexpressivas respiram - o líder acorda num grito. Tenta explicar à mulher: sonhei que... sonhei que... Mas não tem o que contar. Sonhou que era um líder de pessoas vivas.

Para quem assistiu ao filme, para quem está fazendo este curso, para quem acompanhou o momento do golpe e para que faz política neste país, este filme pouco acrescenta. Não há informações novas neste filme.

Para quem viveu o processo midiático em prol do golpe, podemos dizer que o filme dá uma desacelerada na quantidade (de imagens e sons) ao mesmo tempo que intensifica as sensações. O tempo dele é mais lento do que o que vivemos naquele momento, mas mais intenso.

A base da construção do filme se dá com imagens captadas no Senado Federal, mais especificamente no gabinete do Partido dos Trabalhadores-PT onde se concentravam aqueles que defendiam a permanência da Presidenta Dilma. Os dois principais protagonistas neste espaço foram, inicialmente, os senadores Gleise Hoffmann e Lindbergh Farias; posteriormente teremos também a presença e o protagonismo do advogado de defesa José Eduardo Cardozo. A personagem que fará o contraponto com estes três anteriormente indicados, bastante mostrada no filme, será a advogada de acusação Janaína Paschoal, a qual aparecerá principalmente nas imagens e sons captados nas sessões da Comissão Parlamentar de Inquérito-CPI e do Senado Federal.

Em entrevistas sobre o filme, Maria Augusta Ramos afirma que tentou entrevistar e trazer para o filme diversos políticos que estavam defendendo o golpe, mas todos se negaram a lhe dar entrevistas. 
Para manter a força do filme nas proximidades da oralidade, a diretora utiliza muito pouco imagens de arquivo. A principal imagem de arquivo que aparece no filme é a da votação do processo de impeachment na Câmera dos Deputados, a qual foi televisionada na época por diversas emissoras de televisão. Estas imagens praticamente iniciam o filme, sendo vistas logo após as cenas iniciais onde vemos o lado externo do prédio do Congresso Nacional ocupado por manifestantes pró e contra a aprovação do impeachment.

Com exceção das sessões no gabinete do PT, na sala onde se reuniu a CPI e no plenário do Senado, as outras cenas do filme são cenas tranquilas, poderíamos mesmo dizer que são belas e apaziguadoras, em geral bastante luminosas ou iluminadas durante a noite. Estas imagens estabelecem passagens e intervalos entre a tranquilidade distensionada e silenciosa da rotina do cotidiano do Congresso Nacional e os intensos diálogos que sustentam o filme; uma vez que este é um filme fortemente apoiado na palavra falada, essas imagens esvaziadas de palavras contrapõem-se aos corpos tensos dos personagens principais e coadjuvantes que são os senadores e seus assessores. Essas imagens, muitas delas externas, filmadas fora dos prédios do Congresso Nacional, ajudam a compor também uma cronologia dos acontecimentos, fazendo com que os dias se precipitem em direção ao golpe. Cabe dizer, por fim, que essas cenas duram pouco na tela, ainda que, paradoxalmente, busquem criar no espectador a sensação de lentidão, enquanto as cenas de diálogos duram muito e criam em nós tensões constantes e crescentes acelerações.

Tendo essas cenas breves como contraponto, o filme constrói o que chamamos, no cinema, de uma ambiência através de cenas de longa duração. No caso, a ambiência do Senado Federal, e, por isso, sim, ele é importante na construção das sensações que nos provocam sentimentos de raiva, de indignação e até mesmo de ódio. Ou qualquer outro sentimento de desânimo ou de ânimo. Sensações que se transformam em sentimentos. No cinema, a ambiência é um dos procedimentos fílmicos responsáveis pela indução das sensações a determinados sentimentos; ela também é importante para que o espectador seja capturado pela história e possa viver "junto com os personagens" aquilo que eles vivem ou viveram. 
Esta ambiência foi construída nos bastidores do processo de impeachment. O que assistimos nestes bastidores? A que este ambiente (nos) provoca? Que tipo de ritual ele constrói? Poderíamos dizer que seria um ritual absurdo de expiação (para isso, é preciso se remeter ao próprio extracampo que o filme tem que é o próprio espetáculo midiático que levou muitas pessoas a apoiarem o golpe), que fez com que um determinado partido, ou uma determinada personagem, no caso a presidenta, fosse transformada no mal que assombrava o país e que, portanto, deveria ser extirpado. Perde-se, portanto, toda a ideia de lógica, embora o filme se construa não por contraposições da acusação a esta personagem. Só que as falas, no filme, estão em um cenário ritualístico (e extrafílmico) de expiação do mal.

Por este ponto de vista o filme se distancia do livro "O Processo" de Franz Kafka, uma vez que nele não acompanhamos a personagem principal do processo, no entanto, o filme traz sim alguma coisa desta obra que nos ajuda a pensar na frase de Lindbergh Farias: o absurdo.

O estranho ritual de expiação em um processo judiciário talvez tenha sito a inspiração de Lindbergh Farias para comparar o processo de Dilma Rousseff ao processo de Kafka. Mas as possíveis equivalência entre o livro e o filme terminam aí. No livro, $\mathrm{K}$ é o acusado, mas não sabemos por que, do que, nem por quem. Acompanhamos $\mathbf{K}$ percorrendo estranhos caminhos que levam o seu processo para descobrir do que ele é acusado. O personagem central do livro é o próprio acusado. No caso do filme, a personagem é a acusação em sua trajetória e não a vítima da acusação. Dilma aparece muito pouco no filme. O que é construído na cronologia do filme é o processo vivido pela peça (inumana) de acusação e não as ações e os pensamentos vividos pela personagem (humana) acusada.

O filme já começa com Gleise Hoffmann anunciando que "isso tudo é um jogo de cartas marcadas" e que é preciso ganhar tempo para "fazer política". Sabemos, portanto, logo no início, que a acusada seria condenada, ainda que não saibamos qual será o percurso da (peça de) acusação. Em certo momento do filme, a própria Gleise Hoffmann confessará, inclusive, que a governabilidade da presidenta já estava inviabilizada antes mesmo do processo de impeachment se iniciar. 
No livro de Kafka, $\mathrm{K}$ percorre um labirinto de micropoderes que enreda o acusado e os agentes de justiça num processo em que não se sabe a acusação. Mas é o percurso de $\mathrm{K}$ que faz a narrativa acontecer. Alguns agentes da justiça são bizarros e inimagináveis em um processo judicial, tal como o pintor, o padre, as esposas e as amantes de alguns personagens masculinos. O filme de Maria Augusta Ramos não percorre os meandros dos micropoderes, ainda que ele nos faz demorar em alguns dos lugares onde esses micropoderes atuam - no gabinete do PT e na sala de reunião da CPI -, salientando a intensidade e tensões nesses lugares, criando a ambiência em que a defesa tenta fazer política, mesmo sabendo que é um jogo de cartas marcadas pelo macropoderes.

\subsection{Entre colocar em quadro e deixar no extracampo}

A câmera cinematográfica tem uma importância predominante, pois é a mesma que enuncia um filme. Nesse caso, ela acompanha as reverberações da acusação, tornadas falas, caras e diálogos, dentro do gabinete do PT no Senado. Duas das cenas aí filmadas chamam a atenção; elas aparecem como dois longos planos-sequências, ou seja, planos feitos sem corte. Numa delas, Gleise Hoffmann fala sobre a (não) governabilidade citada acima e na outra o político petista Gilberto Carvalho faz uma análise crítica dos governos petistas em tempo real. São duas cenas marcantes e que, de alguma forma, rearticulam tudo o que o filme agencia, tanto as cenas intensas (de disputa) quanto as cenas lentas (de passagem).

No processo de negociação cinematográfica Maria Augusta Ramos não acompanhou a acusação de perto, mas sim suas reverberações na defesa. Talvez uma das razões seja por não poder gravar entrevistas com os políticos que estavam articulando a acusação, talvez por ela não ter tido acesso aos gabinetes onde a acusação se articulava. Sua opção cinematográfica foi, então, deixar a acusação como grande extracampo que pressiona o que está em campo, enquadrado, e acompanhar suas reverberações nos locais e corpos que permitiram a presença da câmera.

Seguindo nessa mirada que articula o que não é mostrado com o que é mostrado, chamamos atenção para o que aparece de uma ma- 
neira breve, sutil. Destacamos aqui duas coisas que eram onipresentes durante o processo, e que eram também onipresentes no filme, só que em extracampo: uma é o espetáculo midiático, ou seja, as grandes câmeras e os grandes microfones, que em determinado momento aparecem sem ninguém (somente a estrutura técnica audiovisual da mídia é que está presente), e a outra onipresença são os celulares e as redes sociais, que em diversos momentos aparecem nas mãos de vários alguéns que conversam e tiram fotos com os políticos personagens do processo. De certa forma, a dobra do espetáculo para dentro das redes socais tem destaque nos advogados José Eduardo Cardozo e Janaína Paschoal, os mais assediados pelas microcâmeras dos celulares.

Sobre a importância do extracampo num filme documentário ${ }^{8}$. Quando fazemos uma imagem, com qualquer tipo de câmera, esta imagem é um recorte do campo visual que o espectador vê. Aquilo que não está sendo visto é construído pelo espectador como uma continuidade desse campo visível na imagem. Quando dizemos que a mídia está no extracampo do filme “O Processo”, estamos fazendo, na verdade, uma metáfora para apontar que ao mesmo tempo que acontece o que acompanhamos no filme estava acontecendo o espetáculo midiático do golpe. Nesse sentido, há uma continuidade (um extracampo) nas imagens e sons do filme da Maria Augusta Ramos que são as imagens e sons que estávamos assistindo no período em que estava acontecendo o processo do impeachment. Gilberto Sobrinho ${ }^{9}$ afirma, inclusive, que o filme "O Processo" diminui a velocidade das imagens (que compõem o extracampo do filme) para que possamos melhor observar o golpe se fazendo existir.

Em outras palavras, só se entende o campo, ou seja, o que estamos vendo, se consideramos o extracampo que esse campo carrega junto, acoplado a ele; o não visível é tornado sensível pelo visível. Nes-

\footnotetext{
${ }^{8}$ Nos parece que esse filme, como documentário, tem uma relação mais impactante conosco (nós da FE, nós da educação), pois é muito comum o uso de documentários em nossas práticas profissionais, em grande medida com a expectativa de utilizá-lo como documento do real a ser apresentado aos alunos. No entanto, esperamos que fique claro, mais adiante, como esse documentário traz para si vários traços dos filmes de ficção, o que não o distancia do real, mas sim aponta o quanto os documentários atuam no real - criam nele outras camadas, outros sentidos, outras sensações - ao mesmo tempo que o documentam.

${ }^{9}$ Ver "O Processo ou as imagens e os sons que nos dominam”. Carta Maior. Disponível em: https://www.cartamaior.com.br/?/Editoria/Cinema/O-Processo-ou-as-imagens-e-os-sons-quenos-dominam/59/40513
} 
se filme é preciso, portanto, não se fixar somente naquilo que se vê, mas estar atento para o que não se vê, mas se (pres)sente. Essa é outra das características do extracampo: é nele onde as nossas expectativas de continuidade do filme estão. Ou seja, nele está aquilo que pode entrar em campo a qualquer momento. Isso pode ser observado de forma muito forte em filmes policiais, de suspense e de perseguição. Nesse filme, esta onipresença do que pode entrar em campo é tanto das microcâmeras dos celulares quando das grandes câmeras da televisão, dobrando sobre ele não só sensações semelhantes às vivenciadas nos filmes policiais e de suspense, mas também sensações (e informações) provenientes das imagens e sons daquele período.

É bom lembrar que a própria câmera que fez a captação das imagens do filme era uma grande câmera (em qualidade e tamanho), mas como ela construía imagens muito semelhantes das pequenas câmeras (que são as que normalmente estão presentes nos locais de reunião), criou-se uma interessante ambiguidade entre estes dois tipos de câmera no filme.

\section{Micropolíticas do filme}

\subsection{Alguns tipos de imagens e sons que o compõem e seus possíveis sentidos}

Primeiro as externas de Brasília, que iniciam o filme e, ao longo dele, apresentam imagens esplêndidas. Estas imagens saem da Câmara dos Deputados e vão para o Senado. São imagens de passagem, conforme já dito anteriormente. Elas compõem o filme trazendo a ele um conjunto de sensações de esvaziamento, de calma, de banalidade, bem como certa leveza, luminosidade, indiferença e, a nosso ver, um certo traço de vingança.

Em segundo lugar destacamos uma cena que enquadra José Eduardo Cardozo com Antonio Anastasia. Nela estamos diante da forma como o grupo que detém o poder de jogar as cartas marcadas está respondendo às nossas palavras e reivindicações: com o absoluto silêncio. Esse poder não precisa responder, nem no filme - onde o silêncio impávido de Anastasia remete ao silêncio das forças que o amparam - nem fora dele, que é o que temos acompanhado com a não 
resposta às reivindicações pautadas em grandes manifestações sociais pelo Brasil afora. Nesta cena, a sensação que fica é de que as forças que estão atuando ali, no processo de impeachment, não são nem a das palavras (dos advogados de acusação e defesa) e nem a da lei (da constituição).

Outro tipo de imagem que vai orientando o espectador no processo e no desenrolar da ação do processo é aquele em que na tela aparecem tarjas pretas com linhas brancas e que transformam o filme em uma obra capitular. Esse tipo de imagem também nos mostra que a montagem realiza uma cronologia, que ela foi feita na mesma ordem temporal da captação das imagens, ampliando a força de documento que o filme nos passa.

Ao manter a cronologia das cenas filmadas, a diretora se colocou em uma espécie de prisão, um dispositivo para montar as imagens e sons segundo a cronologia das filmagens dia após dia. Ela garante assim certa "imparcialidade" ao montar o filme, uma vez que isso pode ser entendido como uma forma de contar a história para que pareça real.

De alguma maneira essa é também uma forma de se apropriar das normas do próprio processo jurídico para tomar partido, uma vez que, nesses processos, as últimas palavras são sempre da defesa; isso ocorrerá tanto no processo quanto nas sequências de embate no filme. Por isso, nas cenas das sessões da CPI a última fala é sempre de José Eduardo Cardozo, aproveitando que as falas da defesa são sempre depois das falas da acusação. Como sabemos, em um filme a última fala tem mais peso sobre as impressões de quem ouve. De uma maneira aparentemente imparcial, "O Processo" se aproveita de uma forma de funcionamento do processo jurídico para deixar em evidência os argumentos e os pronunciamentos da defesa, os quais nos induzem a pensar que o impeachment foi um golpe. Nesse sentido, ainda que não deliberadamente, Maria Augusta Ramos toma partido no processo, utilizando-se da própria cronologia, a qual também é um dado de documento, do sentido documental em que o filme se pauta.

Essa possível interpretação do que é construído como documentário faz voltar a ideia de que a personagem principal dele é a (peça de) acusação ou o seu processo (trâmite no legislativo). Como já apontado, o filme não fala das pessoas, não é um filme que fala dos 
atores políticos em cena; nem sequer nomeia explicitamente vários deles. O filme fala de um processo de acusação. Não é um filme que explica o golpe, mas sim expõe a forma de funcionamento do poder legislativo (onde um golpe estava sendo perpetrado), forma esta que não é apenas uma forma de funcionamento daquele momento, mas sim uma forma habitual, fazendo com que o filme tenha uma grande potência ao expor um espaço legislativo em que as arenas de diálogo e convencimento estão esvaziadas, surdas, com pessoas (políticos) preocupadas com outras coisas vinculadas somente aos seus afazeres, pois onde deveria haver um jogo de argumentos há apenas uma jogo de cartas marcadas. $\mathrm{O}$ filme expõe uma forma de funcionamento que se dá através de negociatas, o que acaba emergindo como sensação naqueles que, com um pouco de sensibilidade, dedicam um olhar atento para o filme.

Se olharmos para o filme de Maria Augusta Ramos e nos perguntarmos onde está a câmera, por exemplo, notamos com facilidade que as principais cenas são as filmagens do gabinete da defesa. A câmera está na roda de conversa, dentro do gabinete como se participasse da conversa, do diálogo e da discussão dos senadores e assessores. A câmera está sentada junto com eles. A câmera está ali como se fosse mais um personagem a discutir o problema, ela constrói para si uma característica participativa, envolvida com os problemas que este grupo está enfrentando.

No entanto, em nenhum momento a documentarista faz alguma interversão ou aparece para falar (fazendo uma pergunta, por exemplo). Certamente houve inúmeras vezes que a diretora ou a equipe falou, mas certamente houve muitas horas de gravação e a diretora selecionou as partes que queria e que foram autorizadas para fazer o filme funcionar, para que ele se sustentasse como obra (de arte), mas em nenhum momento ela intervém na cena que está sendo gravada ou optou por fazer desaparecer as vozes vinculadas ao cinema naquela ambiência, talvez para salientar sua presença como imagem, como observador(a) atento(a).

Tendo em vista os parágrafos acima, pode-se dizer que é justamente no agenciamento cronológico e na escolha do posicionamento de câmera que a diretora tomou partido. Ela filma como se tivesse participando do diálogo e do problema que move o diálogo filmado. 
E este problema se apresenta cronologicamente no filme assim como foi cronologicamente enfrentado, "apenas" para "fazer política”, uma vez que o processo era um jogo de cartas marcadas. No entanto, a presença da equipe de filmagem se fez sempre em silêncio (pelo menos assim o filme nos faz sentir), ainda que o problema do filme tenha sido o mesmo: estamos em um jogo de cartas marcadas em que o processo de impeachment é um golpe. O filme não diz isso explicitamente, mas participa da tensão que esta situação reverbera nos corpos e palavras de seus principais personagens, levando muitos de nós a um sutil processo de identificação com eles.

\subsection{Entre documentário e ficção: informar e afetar e...}

Há uma antiga e interessante discussão na área do cinema sobre as diferenças entre documentário e ficção. Hoje se admite que estas diferenças são mais sutis do que uma distinção ente o que é verdadeiro e o que seria invenção. Documentário não é um cinema que diz uma verdade; este não é seu destino e nem seu objetivo, pois afinal um filme documentário ainda é cinema, uma produção humana, num certo estilo e construído sob certas condições. É preciso sempre olhar com cuidado um filme para tentar descobrir que tipo de documentário ele pretende ser, como ele agencia a captura de imagens e sons e a construção de situações verossímeis, como ele opera com as noções de documento, de realidade, de verdade e como ele também opera com os traços ficcionais que se dobram em sua montagem e edição, em suas imagens e sons, em seus cenários e personagens.

O documentário da Maria Augusta Ramos, por exemplo, não é um documentário do tipo "mosca na parede" que procura esconder a câmera para tentar parecer uma investigação imparcial e dobrar nos gestos dos personagens a sensações de espontaneidade. Também não é um tipo de documentário que reconstitui a realidade para que o espectador veja o que a documentarista havia visto. É sim um documentário que se insere no vivido e o acompanha, extraindo dele aquilo que tem, por assim dizer, potência cinematográfica para afetar o espectador, conectando-o àquela parcela do real em que o filme tocou e, ao mesmo tempo, fazendo-o sentir algo novo em relação àquela realidade. 
Nesse sentido, "O Processo" coloca a questão da imparcialidade do documentário como um de seus temas. Essa é uma questão há muito debatida, mas hoje é quase consenso de que não existe imparcialidade na construção fílmica, nem na captura de imagens e nem na montagem do filme. Entende-se que seus diretores (produtores, montadores etc.) deixam rastros mais ou menos sensíveis em suas obras, conscientemente ou não.

O cinema, entendido como arte - diferente da televisão, que é mais voltada à comunicação e organização de informações referenciais -, está em busca de imagens que contêm alguma coisa a mais, que impregnem seus espectadores de algo mais que informações. A arte do cinema documentário é exatamente desfazer-se, em certa medida, do desejo de comunicar e informar para deixar-se penetrar pela invenção e experimentação de outros modos de produção cinematográfica, outros modos de criação fílmica. É nesse sentido que o cinema de Maria Augusta Ramos pode desfazer-se da necessidade de identificar todas as pessoas (nesse caso, políticos e assessores) que atuaram como personagens.

No filme "O Processo" não temos propriamente Gleise Hoffmann na tela, mas sim uma personagem, uma mulher loira, com um determinado tipo de fisionomia, com um certo tom de voz que aparece ao longo de todo filme, oscilando em funções dos humores e tensões vivenciadas pela personagem. Desta forma, independente de quem ela seja, daqui a 30 anos este conjunto de oscilações, de raiva e de inteligência desta personagem estarão ali postos, visíveis e produzindo um conjunto de sensações nos espectadores, ainda que certamente não as mesmas sensações que temos nós, que conhecemos a senadora fora do filme. De alguma forma, essa é uma dobra da ficção no documentário: Gleisi Hoffmann vira uma personagem de um processo. Qual processo? Qualquer um, entre tantos que ocorrem no país e no mundo. É como tal que Gleise Hoffmann torna-se a heroína do filme, não só pela gentileza com que a câmera a mostra, mas também porque uma das frases-chave do filme é dita por ela: "isso é um jogo de cartas marcadas, portanto vamos fazer política, ganhar tempo, dar tempo, deixar passar o tempo".

Como contraponto a essa heroína, o filme cria certa bufonaria do lado da acusação e isso fica marcado principalmente nas cenas em 
que Janaína Paschoal é filmada, e tornada a grande vilã, mas também está presente na cena da troca da companhia. Esta última cena citada é, do ponto de vista documental, exasperadora, ou seja, dobra nos espectadores um conjunto de sensações incômodas e justo por isso ela nos coloca muito mais radicalmente dentro daquele lugar, do clima que ali se vivia, do que se somente se contasse a história e não houvéssemos acompanhado a lenta e aparentemente desnecessária troca da campainha.

Maria Augusta deixa estas cenas no filme, construindo uma espécie de personagens bufões, ao mesmo tempo que ela apresenta a inteligência e a calma cuidadosas de José Eduardo Cardozo, deixando discursos inteiros dele. Em meio a isso, a "neutralidade" da CPI é apresentada no filme como um rosto imperturbável e um silêncio controlado, quase cínico, na figura do relator do processo de impeachment, Antonio Anastasia, que não fala nada o filme inteiro, não demonstrando qualquer alteração no rosto mesmo nos momentos em que é citado pelo advogado de defesa.

Talvez pudéssemos dizer que o filme toma partido e dá a vitória a quem perdeu o processo, construindo rostos de empatia aos perdedores e de antipatia aos ganhadores. A câmera fixa em Janaína e em Anastasia faz os rostos deles derreterem; seus rostos se deformam pelo tempo de exposição, as expressões maníacas de Janaína e a expressão robotizada de Anastasia nos apresentam aquilo que poderíamos chamar, metaforicamente, "as duas faces do mal”. É nesse sentido que podemos afirmar que em um filme, estamos sempre diante de poderosas formas de subjetivação, de poderosos agenciamentos de afetos através de imagens e sons.

Ainda assim, "O Processo" é um filme documentário e é como tal que nos provoca um conjunto de sensações e não só um conjunto de informações. Nele, as informações estão compostas, estão atravessadas por este conjunto de sensações que é vivenciado, experimentado pelo espectador como atos de espiar e expiar algo.

Nesse caso, como o filme foi montado quando o processo de impeachment já havia terminado, ele pode ser posto com mais intensidade como um processo de expiação, de alívio, ao mesmo tempo que ele espiou de perto o processo de defesa cujo desfecho sabíamos antes mesmo do filme começar. E mesmo assim, em vários momentos, cer- 
tamente torcemos para que os heróis saíssem vitoriosos... mesmo que somente no cinema. 



\section{SOBRE OS AUTORES}

Barnabé Medeiros Filho Jornalista e autor, entre outros, do livro "1964 - O golpe que marcou a ferro uma geração”, publicado por esta mesma editora.

Dermeval Saviani

Professor Emérito da UNICAMP, Pesquisador Emérito do CNPq, Coordenador Geral do HISTEDBR e Professor Titular Colaborador Pleno do Programa de Pós-Graduação em Educação da UNICAMP.

\section{José Claudinei Lombardi}

Professor titular do Departamento de Filosofia e História da Educação (DEFHE), da Faculdade de Educação da UNICAMP. Coordenador executivo do Grupo de Estudos e Pesquisas "História, Sociedade e Educação no Brasil” - HISTEDBR. Bolsista produtividade do CNPq.

Marcos R. Lima

Professor da rede pública estadual de São Paulo. Pesquisador do Grupo de Estudos e Pesquisas "História, Sociedade e Educação no Brasil" - HISTEDBR / Unicamp.

Debora Mazza

Professora do Departamento de Ciências Sociais e Educação (DECISE). Diretora Associada da Faculdade de Educação (FE) da Universidade Estadual de Campinas (Unicamp) (2016-2020). Membro do Grupo de Estudos e Pesquisa em Políticas, Educação e Sociedade (GPPES) da mesma universidade.

\section{Reginaldo Corrêa de Moraes}

Professor titular do Instituto de Filosofia e Ciências Humanas da Universidade Estadual de Campinas (UNICAMP) e pesquisador do Instituto Nacional de Ciência e Tecnologia para Estudos sobre os Estados Unidos (INCT-Ineu). 


\section{Roberto Heloani}

Professor titular do Departamento de Políticas, Administração e Sistemas Educacionais (DEPASE) e pesquisador do Grupo de Trabalho e Subjetividade (NETS) da Faculdade de Educação da UNICAMP.

\section{Evaldo Piolli}

Docente do Departamento de Políticas, Administração e Sistemas Educacionais (DEPASE) e pesquisador do Laboratório de Gestão Educacional - LAGE da Faculdade de Educação da UNICAMP.

\section{Dirce Zan}

Docente do Departamento de Ensino e Práticas Culturais (DEPRAC) e diretora da Faculdade de Educação (FE) da Universidade Estadual de Campinas (Unicamp) (2016-2020). Membro do Grupo de Estudos e Pesquisa em Políticas, Educação e Sociedade (GPPES) da mesma universidade.

\section{Nora Krawczyk}

Docente do Departamento de Ciências Sociais e Educação (DECISE) e Membro do Grupo de Estudos e Pesquisa em Políticas, Educação e Sociedade (GPPES) da Faculdade de Educação (FE) da Universidade Estadual de Campinas (Unicamp). Coordenadora do Grupo Interinstitucional de Ensino Médio em Pesquisa (EMpesquisa)

\section{Nima I. Spigolon}

Docente do Departamento de Políticas, Administração e Sistemas Educacionais (DEPASE). Pesquisadora do Grupo de Estudos e Pesquisas em Educação de Jovens e Adultos - GEPEJA e do Grupo de Estudos e Pesquisa em Políticas, Educação e Sociedade (GPPES).

\section{Cristiane Machado}

Docente no Departamento de Políticas, Administração e Sistemas Educacionais - DEPASE e Vice-coordenadora do Laboratório de Gestão Educacional - LAGE da Faculdade de Educação, UNICAMP. 
Mara Regina Martins Jacomeli

Docente do Departamento de Filosofia e História da Educação (DEFHE) e Coordenadora local do Grupo de Pesquisa do HISTEDBR (História, Sociedade e Educação no Brasil).

\section{Marcia Lucia Anacleto Souza}

Professora de Educação Básica da Prefeitura Municipal de Campinas , Brasil. Atua na formação docente em Educação para as Relações Étnico-Raciais. Pesquisadora do Grupo de Estudos e Pesquisas em Diferenciação Sócio-Cultural (GEPEDISC)

\section{Ana Lúcia Goulart de Faria}

Professora colaboradora da Pós-Graduação em Educação da Faculdade de Educação da Uicamp e pesquisadora do Grupo de Estudos e Pesquisas em Diferenciação Sócio-Cultural (GEPEDISC) da mesma instituição.

\section{Carlos Eduardo Albuquerque Miranda}

Docente do Departamento de Educação Conhecimento, Linguagem e Arte (DELART) e pesquisador do Laboratório de Estudos Audiovisuais - OLHO, da Faculdade de Educação, Unicamp

\section{Wenceslao Machado de Oliveira Junior}

Docente do Departamento de Educação Conhecimento, Linguagem e Arte (DELART) e pesquisador do Laboratório de Estudos Audiovisuais - OLHO, da Faculdade de Educação, Unicamp 

Esperamos que esse livro contribua para o debate político e filosófico sobre a educação. Afirmamos que caso seja infringido qualquer direito autoral, imediatamente, retiraremos a obra da internet. Reafirmamos que é vedada a comercialização deste produto.

Título

Orgs.

Formato

$1^{a}$ Edição
O golpe de 2016 e a educação no Brasil

Nora Krawczyk \& José Claudinei Lombardi

A5

Dezembro de 2018

\author{
Navegando Publicações

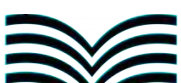 \\ NAVEGANDO \\ www.editoranavegando.com \\ editoranavegando@gmail.com \\ Uberlândia - MG \\ Brasil
}




O presente livro reúne os textos resultantes das conferências proferidas, ao longo do primeiro semestre de 2018, no curso livre "O golpe de 2016 e a Educação no Brasil", promovido pela Faculdade de Educação da Unicamp. Foi uma iniciativa tomada por docentes das mais diversas universidades brasileiras, praticamente em todas as regiões do território nacional, em promoverem cursos e seminários de teor semelhante ao promovido pelo Instituto de Ciência Política da Universidade de Brasília e que, por seu conteúdo e temática, sofreu fortes críticas e ameaça de processo judicial vindas do então Ministro da Educação. [...] O livro aqui apresentado, tal como o curso que lhe deu origem, tem por objetivo [...] defender a função fundamental da universidade, tão atacada nos últimos tempos: pesquisar de modo livre, crítico e independente, socializando os conhecimentos e reflexões produzidas através de um ensino público, gratuito, competente e socialmente referenciado.

Com o curso livre "O golpe de 2016 e a Educação no Brasil" e agora com o lançamento deste livro, a Faculdade de Educação da Unicamp reafirma, mais uma vez, seu compromisso com a construção de uma sociedade e de uma universidade regida pelo princípio democrático. Nestes tempos em que avança aceleradamente o desmonte da educação pública e sua mercadorização, reiteradamente os docentes, funcionários e alunos da FE tem se manifestado em defesa da educação pública, gratuita, competente e socialmente referenciada.

Nora Krawczyk - José Claudinei Lombardi 